\title{
Microfluidic devices for sample preparation and rapid detection of foodborne pathogens
}

Kant, Krishna; Shahbazi, Mohammad-Ali; Dave, Vivek Priy; Ngo, Tien Anh; Aaydha Chidambara, Vinayaka; Than Linh, Quyen; Bang, Dang Duong; Wolff, Anders

\author{
Published in: \\ Biotechnology Advances
}

Link to article, DOI:

10.1016/j.biotechadv.2018.03.002

Publication date:

2018

Document Version

Peer reviewed version

Link back to DTU Orbit

Citation (APA):

Kant, K., Shahbazi, M-A., Dave, V. P., Ngo, T. A., Aaydha Chidambara, V., Than Linh, Q., Bang, D. D., \& Wolff, A. (2018). Microfluidic devices for sample preparation and rapid detection of foodborne pathogens.

Biotechnology Advances, 36(4), 1003-1024. https://doi.org/10.1016/j.biotechadv.2018.03.002

\section{General rights}

Copyright and moral rights for the publications made accessible in the public portal are retained by the authors and/or other copyright owners and it is a condition of accessing publications that users recognise and abide by the legal requirements associated with these rights.

- Users may download and print one copy of any publication from the public portal for the purpose of private study or research.

- You may not further distribute the material or use it for any profit-making activity or commercial gain

- You may freely distribute the URL identifying the publication in the public portal 


\section{Accepted Manuscript}

Microfluidic devices for sample preparation and rapid detection of foodborne pathogens

Krishna Kant, Mohammad-Ali Shahbazi, Vivek Priy Dave, Tien Anh Ngo, Vinayaka Aaydha Chidambara, Quyen Than Linh, Dang Duong Bang, Anders Wolff
PII:
S0734-9750(18)30040-5
DOI: doi:10.1016/j.biotechadv.2018.03.002
Reference: JBA 7228
To appear in: Biotechnology Advances
Received date:
12 October 2017
Revised date:
14 February 2018
Accepted date:
8 March 2018

Please cite this article as: Krishna Kant, Mohammad-Ali Shahbazi, Vivek Priy Dave, Tien Anh Ngo, Vinayaka Aaydha Chidambara, Quyen Than Linh, Dang Duong Bang, Anders Wolff, Microfluidic devices for sample preparation and rapid detection of foodborne pathogens. The address for the corresponding author was captured as affiliation for all authors. Please check if appropriate. Jba(2018), doi:10.1016/j.biotechadv.2018.03.002

This is a PDF file of an unedited manuscript that has been accepted for publication. As a service to our customers we are providing this early version of the manuscript. The manuscript will undergo copyediting, typesetting, and review of the resulting proof before it is published in its final form. Please note that during the production process errors may be discovered which could affect the content, and all legal disclaimers that apply to the journal pertain. 


\section{Microfluidic devices for sample preparation and rapid detection of foodborne pathogens}

Krishna Kant ${ }^{a, \dagger}$, Mohammad-Ali Shahbazi ${ }^{a, t}$, Vivek Priy Dave ${ }^{b}$, Tien Anh $\mathrm{Ngo}^{b}$, Vinayaka Aaydha Chidambara ${ }^{b}$, Quyen Than Linh ${ }^{a, b}$, Dang Duong Bang ${ }^{b}$ and Anders Wolff ${ }^{a,{ }^{*}}$

a Department of Micro- and Nanotechnology, Technical University of Denmark, Ørsteds Plads, DK-2800 Kgs, Lyngby, Denmark

${ }^{b}$ Laboratory of Applied Micro and Nanotechnology (LAMINATE), National Food Institute (DTU-Food), Technical University of Denmark, Denmark

t These authors contributed equally to this work.

*Address correspondence to

anders.wolff@nanotech.dtu.dk

Phone: +45 45256305

Mobile: +4522450209 


\section{Abstract}

Rapid detection of foodborne pathogens at an early stage is imperative for preventing the outbreak of foodborne diseases, known as serious threats to human health. Conventional bacterial culturing methods for foodborne pathogen detection are time consuming, laborious, and with poor pathogen diagnosis competences. This has prompted researchers to call the current status of detection approaches into question and leverage new technologies for superior pathogen sensing outcomes. Novel strategies mainly rely on incorporating all the steps from sample preparation to detection in miniaturized devices for online monitoring of pathogens with high accuracy and sensitivity in a time-saving and cost effective manner. Lab on chip is a blooming area in diagnosis, which exploits different mechanical and biological techniques to detect very low concentrations of pathogens in food samples. This is achieved through streamlining the sample handling and concentrating procedures, which will subsequently reduce human errors and enhance the accuracy of the sensing methods. Integration of sample preparation techniques into these devices can effectively minimize the impact of complex food matrix on pathogen diagnosis and improve the limit of detections. Integration of pathogen capturing bio-receptors on microfluidic devices is a crucial step, which can facilitate recognition abilities in harsh chemical and physical conditions, offering a great commercial benefit to the foodmanufacturing sector. This article reviews recent advances in current state-of-the-art of sample preparation and concentration from food matrices with focus on bacterial capturing methods and sensing technologies, along with their advantages and limitations when integrated into microfluidic devices for online rapid detection of pathogens in foods and food production line.

Keywords: Microfluidic Device, Foodborne Pathogen, Lab-on-a-Chip, Point of Care Detection, Optical Biosensor, Electrochemical Biosensor, DNA Amplification, Immunological Detection, Acoustophoresis, Magnetophoresis 


\section{Introduction}

Foodborne diseases, caused by the consumption of foods contaminated with pathogens or their toxins, are one of the major burdens to public health, causing a significant impediment to socioeconomic development worldwide (Newman et al., 2015). The use of unhygienic water in food processing, poor food handling, inadequate food storage infrastructure, and poorly enforced regulatory standards, are the primary contributing factors for the outbreak of foodborne diseases. According to World Health Organization (WHO), around 600 million illnesses and 420,000 deaths in 2010 were attributed to diseases associated with various pathogens in food products (WHO, 2015). The U.S. Public Health Service has identified the main microorganisms responsible for foodborne diseases, listed in Table 1 (CDC, 2017; IFSAC, 2017; Scallan et al., 2015). Among these pathogens, Norovirus is responsible for $37 \%$ of viral foodborne outbreaks and Salmonella causes $34 \%$ of bacterial foodborne outbreaks (CDC, 2017). To cope with this global challenge and provide safe food for consumers, rapid detection of foodborne pathogens is needed. Over the last decades, great effort has been made for rapid detection of foodborne pathogens in food samples. Nevertheless, two of the most challenging issues, including i) limitations of sample preparation from food matrix and ii) sensitivity of detection methods still remained unsolved. In addition to conventional bacterial culturing, a variety of other approaches, such as nucleic acid-based (e.g., PCR, LAMP, NASBA, RPA, and Helicase), immunological-based (e.g., LFD, ELISA, and ELFA), and biosensor-based (e.g., optical, electrochemical, and mass-based biosensors) methods are used for rapid detection of foodborne pathogen in food samples (Law et al., 2014; Mandal et al., 2011; Zhao et al., 2014). The working principles of these methods are well known and have been exceedingly employed to quantify foodborne pathogens with high sensitivity and specificity 
(Law et al., 2015; Zhao et al., 2014). Due to the complexity of food matrix, these methods often require expensive equipment, well-trained operators, and labour-intensive processing steps, which are not suitable for online testing. Therefore, simple, rapid, accurate, inexpensive, real-time, portable, and easy-to-use methods are needed for on demand detection of pathogens in food matrices. This will require further advance and adaptation of new revolutionary technologies to facile rapid diagnosis of foodborne pathogens. In recent years, intensive researches on microfluidic systems have generated powerful tools for diagnostic applications. These progresses are achieved due to advantages associated with miniaturization, i.e. improved sensitivity and specificity, automation, portability, versatility in design, multiple and parallel sample detection, minimal handling of hazardous materials, and time and cost savings (Kumar et al., 2013; Lei, 2012; Tasoglu et al., 2013). Additionally, all analytical processes, such as sample pre-treatment, separation, chemical reactions, and real-time quantification can be integrated into a single microfluidic platform for at site testing applications (Wang et al., 2015). Several microfluidic platforms have been reported for this purpose using various techniques (Duarte et al., 2013; Lei, 2012; Mairhofer et al., 2009; Tasoglu et al., 2013). For example, a prototype of nano-porous silicon sensor array, integrated on a microfluidic platform, was used for sensitive, rapid and simultaneous detection of multi-pathogens (Tan et al., 2011). However, microfluidic-based methods for the detection of bacterial pathogens in foods are still challenging due to the complex matrices of the food samples and limitations related to the integration of different crucial steps, such as sample pre-treatment, assay operations and detection on a single microfluidic chip (Kim et al., 2014). In addition, the requirement of small volume of sample in microfluidic channels might render certain hurdles in terms of desirable sensitivity, selectivity, and stability of the microfluidics sensors. Attaining 
desirable physico-mechanical properties along with considerations regarding the dominant impact of surface forces, sample transition and integration of efficient recognition molecules on the micro-scaled platform are other challenging issues for the development of such devices (Foudeh et al., 2012). Many strategies, such as gravitational, electrical, magnetic, acoustic, affinity chemistry, hydrodynamic, etc., have been developed to alleviate unsolved issues related to rapid separation, enrichment and detection of foodborne pathogens by microfluidic devices (Foudeh et al., 2012; Mairhofer et al., 2009; P. K. Mandal et al., 2011; Velusamy et al., 2010; Zaytseva et al., 2005; Zhao et al., 2014). Still, it is believed that this area of research is in its infancy and additional efforts are required to facilitate concentration and detection of pathogens.

In this review, we provide a comprehensive discussion over recent developments in integrated-microfluidic systems for concentration and detection of foodborne pathogens in food samples and describe the most promising strategies that can cope with current shortcomings and challenges of rapid on line detection. We will first review the current advances in bio-recognition ligands applied for the capturing of the pathogens on the microfluidic devices. Next, we will provide an overview of recent achievements and strategies for sample preparation using microfluidic technology along with advantages and drawbacks of each method for day-to-day use on microfluidic devices. Current technologies used for the detection of pathogens will also be reviewed before discussing perspectives and outlook for microfluidic detection of foodborne pathogens. 
Table 1. The most common pathogens involved in foodborne diseases (CDC, 2017;

IFSAC, 2017; Scallan et al., 2015).

\begin{tabular}{|c|c|c|c|}
\hline \multicolumn{2}{|c|}{ Pathogens } & Relationship to foodborne diseases & Main source \\
\hline Viral & Norovirus & The leading viral cause of diarrhoea & $\begin{array}{l}\text { Any food } \\
\text { contaminated with this } \\
\text { virus, including } \\
\text { vegetables, fruits, } \\
\text { meat., etc. }\end{array}$ \\
\hline \multirow{7}{*}{ Bacterial } & Salmonella & $\begin{array}{l}\text { One of the most common bacterial cause of } \\
\text { diarrhoea and the most common cause of } \\
\text { foodborne deaths }\end{array}$ & $\begin{array}{l}\text { Seeded vegetables, } \\
\text { eggs, chicken, pork, } \\
\text { beef, and fruits }\end{array}$ \\
\hline & E. coli O157: $\mathrm{H} 7$ & $\begin{array}{l}\text { Produces a deadly toxin that causes severe } \\
\text { cramps, bloody diarrhoea, renal failure, and } \\
\text { vomiting }\end{array}$ & $\begin{array}{l}\text { Vegetable, raw crops } \\
\text { (e.g., leafy } \\
\text { vegetables) and beef }\end{array}$ \\
\hline & $\begin{array}{l}\text { Listeria } \\
\text { monocytogenes }\end{array}$ & $\begin{array}{l}\text { The bacterium causes a serious disease (listeriosis) } \\
\text { for pregnant women, newborns, and adults with a } \\
\text { weakened immune system }\end{array}$ & Fruits and dairy \\
\hline & Campylobacter & Common causes of bacterial diarrhoea & $\begin{array}{l}\text { Chicken, other } \\
\text { seafood, seeded } \\
\text { vegetables, vegetable } \\
\text { row crops, and other } \\
\text { meat/poultry }\end{array}$ \\
\hline & $\begin{array}{l}\text { Clostridium } \\
\text { botulinum }\end{array}$ & $\begin{array}{l}\text { This strain secretes a toxin causing botulism, which } \\
\text { can be fatal. }\end{array}$ & $\begin{array}{l}\text { Home-canned foods } \\
\text { (e.g., green beans, } \\
\text { corn, and beets), root } \\
\text { and other } \\
\text { underground } \\
\text { vegetables }\end{array}$ \\
\hline & $\begin{array}{l}\text { Staphylococcus } \\
\text { aureus }\end{array}$ & $\begin{array}{l}\text { The bacterium secretes a toxin that causes } \\
\text { vomiting shortly after being ingested. }\end{array}$ & $\begin{array}{l}\text { Cooked foods high in } \\
\text { protein (e.g., cooked } \\
\text { ham, salads, bakery } \\
\text { products, dairy } \\
\text { products, chicken) } \\
\text { that are held too long } \\
\text { at room temperature }\end{array}$ \\
\hline & $\begin{array}{l}\text { Clostridium } \\
\text { perfringens }\end{array}$ & Produces a toxin in the intestine that causes illness & $\begin{array}{l}\text { Beef, poultry, gravies, } \\
\text { and dried or pre- } \\
\text { cooked foods }\end{array}$ \\
\hline Parasitic & $\begin{array}{l}\text { Toxoplasma } \\
\text { gondii }\end{array}$ & $\begin{array}{l}\text { Causing toxoplasmosis and central nervous system } \\
\text { disorders (e.g., mental retardation and visual } \\
\text { impairment in children) }\end{array}$ & $\begin{array}{l}\text { Raw and half-cooked } \\
\text { pork }\end{array}$ \\
\hline
\end{tabular}




\section{Bio-recognition ligands for foodborne pathogen detection on microfluidic devices}

It is a critical challenge to detect pathogens from a complex food matrix. A strategy used to address this issue is through highly specific interaction between surface antigenic biomarkers of pathogens and recognition ligands. These ligands can be used to concentrate and identify target pathogens on microfluidic devices. In the case of bacteria, there are a number of bacterial surface antigenic markers, such as virulence factors, adhesins, capsular polysaccharides, lipopolysaccharide (LPS), teichoic acids, surface glycoproteins, fimbriae, etc., that are employed for diagnostic purposes. The capsular polysaccharides are repeating units of oligosaccharides possessing unique structures for particular bacterial strains (Roberts, 1996). LPS, also known as endotoxins, are glycolipids on the outer surface membrane of Gram-negative bacteria (Alexander and Pfaller, 2006). Teichoic acids are generally found on the surface of Gram-positive bacteria as a cell wall component (Weidenmaier and Peschel, 2008) while surface glycoproteins can be found on the surface of both Gram-positive and Gram-negative bacteria (Flemming and Wingender, 2010). In general, several different types of bio-recognition molecules, such as antibodies, peptides, aptamers or bacteriophages can be used for efficient pathogen capturing (Perumal and Hashim, 2014; Singh et al., 2014). Figure 1 gives an overview of available motifs on the surface of different pathogens as well as capturing agents that can be used for enrichment or concentration of foodborne pathogens on microfluidic devices. 


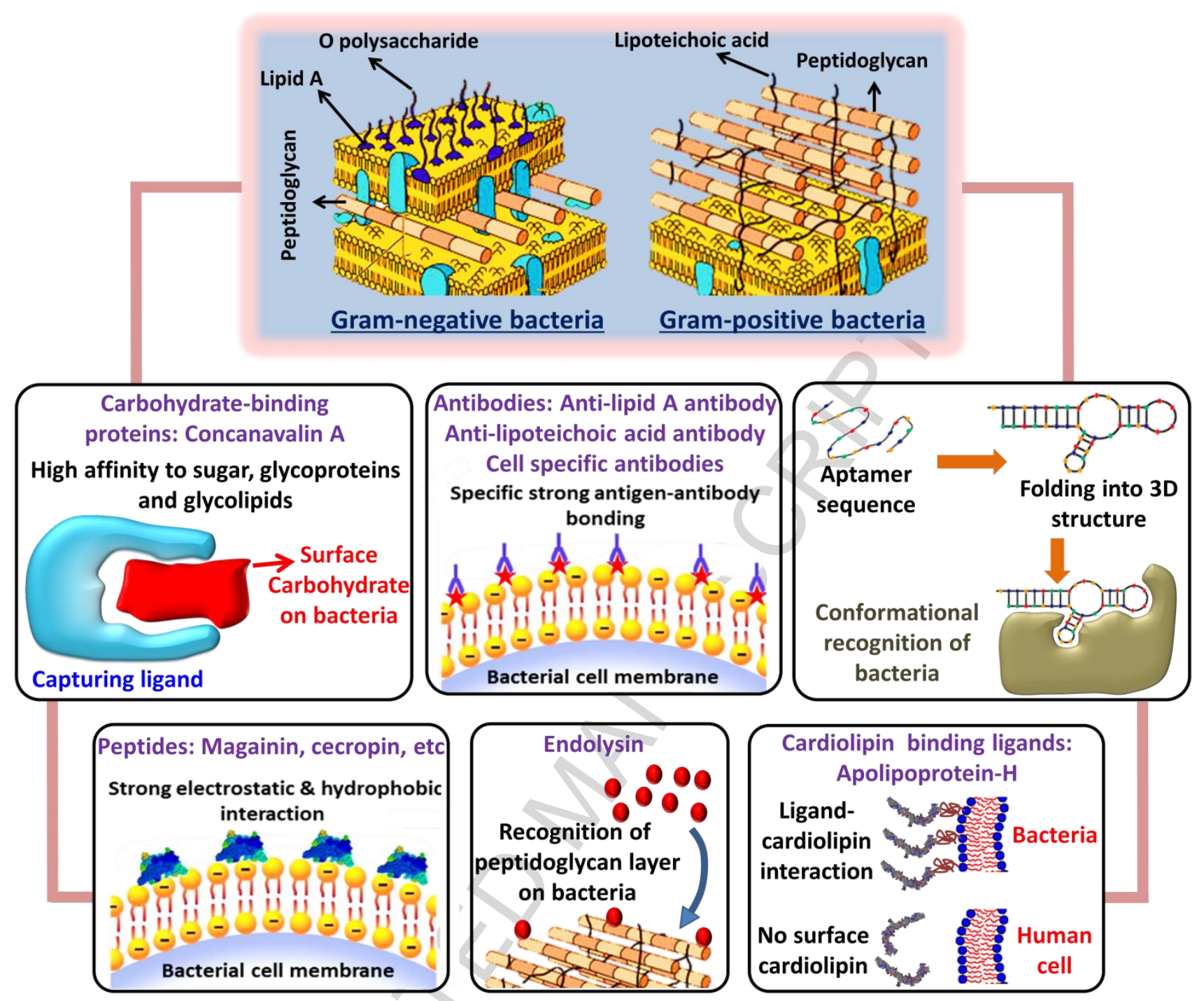

Figure 1. Schematic overview of surface bio-recognition motifs of bacterial pathogens and ligands that can be used for capturing the bacteria. Carbohydrate-binding proteins, antibodies, aptamers, peptides, endolysin, and cardiolipin binding ligands are the main capturing agents, which have been investigated for enrichment or concentration of foodborne pathogens. The capturing mechanisms are illustrated for all the ligands. Depending on the surface properties of target pathogen, particular types of ligands can be used to capture pathogens.

\subsection{Antibodies}

High-affinity pathogen separation by specific interactions between antigens and their respective antibodies is a well-known mechanism most widely applied in microfluidic devices. Guan et al. (2010) reported the integration of glass beads, covalently immobilized with anti-E. coli $\mathrm{O} 157: \mathrm{H} 7$ antibody, in a microfluidic chip to detect $E$. coli $\mathrm{O} 157: \mathrm{H} 7$ at a 
concentration range from $3.2 \times 10^{1} \mathrm{CFU} / \mu \mathrm{l}$ to $3.2 \times 10^{5} \mathrm{CFU} / \mu \mathrm{l}$ within $20 \mathrm{~min}$. Integration of microbeads on miniaturized devices can solve the limitations regarding the low surface area of planar microchannels available for antibody-pathogen binding. This study demonstrated excellent reproducibility and stability, while being able to specifically and accurately detect the pathogenic bacteria in food samples. In another example, antibody modified magnetic nanoparticles were used for bacterial capturing in a circular microfluidic polydimethylsiloxane (PDMS) chip using permanent magnets, embedded beneath the microchannels for multiplexed detection of waterborne pathogens (Agrawal et al., 2012). Anti-E. coli antibody and anti-Salmonella typhimurium antibody were used for capturing the bacteria, while CdTe quantum dots (QDs) with two different fluorescent colours were used as detector probes conjugated to anti-E. coli and anti-Salmonella typhimurium ( $S$. typhimurium) antibodies. This approach resulted in efficient capturing of bacteria and enhanced fluorescence signal, allowing simultaneous detection of pathogens with a limit of detection (LOD) of $10^{3}-10^{7} \mathrm{CFU} / \mathrm{ml}$ in a $20-\mu$ l sample. Antibody-coated magnetic bead integrated with the centrifugal microfluidic device is also reported for capturing and detection of Salmonella in spiked milk samples (Kim et al., 2014). Through the combining of DNA extraction and isothermal Recombinase Polymerase Amplification (RPA) in a single centrifugal microfluidic device, Salmonella could be detected in milk within $30 \mathrm{~min}$ in a fully automated fashion with a detection limit of $10^{2} \mathrm{CFU} / \mathrm{ml}$. Bacterial capturing efficiencies of $90 \%$ and $43 \%$ were achieved in PBS when $10^{2}-10^{4} \mathrm{CFU} / \mathrm{ml}$ and $10 \mathrm{CFU} / \mathrm{ml}$ of Salmonella were spiked, respectively. Salmonella spiked milk samples showed a relatively lower efficiency $(<30 \%)$ due to the inhibiting effect of milk matrix on the binding of target pathogens to the antibodies. An antibody-integrated lab-on-a-chip (LOC) device is also reported for water borne pathogen detection using Immuno-Nucleic Acid Sequence 
Based Amplification (NASBA) technique (Zhao et al., 2012). This device was able to detect E. coli and rotavirus at concentrations from $10^{-9} \mathrm{~mol} / \mathrm{L}$ to $10^{-16} \mathrm{~mol} / \mathrm{L}$. An impedimetricmicrofluidic sensor has also been developed for the detection of $S$. typhimurium using monoclonal anti-Salmonella antibodies immobilized on a high-density interdigitated electrode array (Ghosh Dastider et al., 2015). One of the main features of this device is its capability to provide qualitative and quantitative results in 3 hours with a detection limit of $3 \times 10^{3} \mathrm{CFU} / \mathrm{ml}$, without any enrichment step. It is shown that the immobilization of antibodies on the interdigitated electrode array can significantly improve the impedance response ( 3 times) and increase the sensitivity by 10 -fold, owing to increased number of target cells per unit volume in the detection region. Another novel aspect is the use of antibody mediated QD based sandwich fluorescence technique in a microfluidic chip. Wang et al. (2015) reported the integration of light-emitting diode-induced fluorescence detection (LIF) microsystem in a multichannel microfluidic chip for detecting of $S$. typhimurium in pork samples. Using this system, a detection limit of $37 \mathrm{CFU} / \mathrm{ml}$ was achieved and the sensitivity of the assay were improved when CdSe/ZnS QDs were used as fluorescent detecting markers. Despite all the advances of antibody mediated foodborne pathogen concentration and detection in microfluidic devices, a number of drawbacks, such as batch-to-batch variation, the possibility of cross-reactions between different target motifs, high cost, and poor chemical and physical stability of antibodies are known as hurdles that force scientists to study other alternative bio-recognition ligands (Sapsford et al., 2008). Table 2 represents detail information of some new advances in foodborne sample preparation using antibodies and other alternative ligands, which are discussed in the next sections. 
Table 2. Examples of foodborne pathogen concentration using different capturing ligands.

\begin{tabular}{|c|c|c|c|c|c|}
\hline Target pathogen & $\begin{array}{l}\text { Capturing } \\
\text { Ligand }\end{array}$ & Sample type & $\begin{array}{l}\text { Limit of } \\
\text { detection } \\
\text { (LOD) }\end{array}$ & $\begin{array}{l}\text { Detection } \\
\text { principle }\end{array}$ & Reference \\
\hline E. coli & $\begin{array}{l}\text { Antibody } \\
\text { immobilized on } \\
\text { magnetic } \\
\text { nanoparticle } \\
\text { clusters } \\
\text { (MNCs) }\end{array}$ & Milk & $\begin{array}{l}10 \mathrm{CFU} / \mathrm{ml} \text { in } \\
\text { PBS } \\
100 \mathrm{CFU} / \mathrm{ml} \text { in } \\
\text { milk samples }\end{array}$ & $\begin{array}{l}\text { Absorbance and } \\
\text { Luminescence }\end{array}$ & $\begin{array}{l}\text { (Law et al., } \\
2015)\end{array}$ \\
\hline E. coli K12 & $\begin{array}{l}\text { Antibody } \\
\text { immobilized on } \\
\text { magnetic } \\
\text { beads }\end{array}$ & Milk & $100 \mathrm{CFU} / \mathrm{ml}$ & $\begin{array}{l}\text { Amperometric } \\
\text { sensor }\end{array}$ & $\begin{array}{l}\text { (Laczka et } \\
\text { al., 2011) }\end{array}$ \\
\hline E. coli O157:H7 & Antibody & Water & $1 \mathrm{CFU} / \mathrm{ml}$ & qPCR & $\begin{array}{l}\text { (Dharmasiri } \\
\text { et al., 2010) }\end{array}$ \\
\hline $\begin{array}{l}\text { E. coli O157:H7 } \\
\text { E. coli K12 }\end{array}$ & $\begin{array}{l}\text { Antibody } \\
\text { immobilized on } \\
\text { latex } \\
\text { microbeads }\end{array}$ & Iceberg lettuce & $10 \mathrm{CFU} / \mathrm{ml}$ & $\begin{array}{l}\text { Mie light } \\
\text { scattering } \\
\text { principle }\end{array}$ & $\begin{array}{l}\text { (You et al., } \\
\text { 2011) }\end{array}$ \\
\hline $\begin{array}{l}\text { E. coli, } \\
\text { Rotavirus }\end{array}$ & $\begin{array}{l}\text { Antibody } \\
\text { immobilized in } \\
\text { microchip }\end{array}$ & Water & $\begin{array}{l}10^{-9} \mathrm{~mol} / /-10^{-16} \\
\mathrm{~mol} / /\end{array}$ & PCR & $\begin{array}{l}\text { (Zhao et al., } \\
2012 \text { ) }\end{array}$ \\
\hline $\begin{array}{l}\text { E. coli and } \\
\text { Salmonella }\end{array}$ & $\begin{array}{l}\text { Magainin I } \\
\text { peptide }\end{array}$ & Water & 1 bacterium/ $\mu l$ & Impedometry & $\begin{array}{l}\text { (Mannoor et } \\
\text { al., 2010) }\end{array}$ \\
\hline S. typhimurium & $\begin{array}{l}\text { Antibody } \\
\text { immobilized on } \\
\text { magnetic } \\
\text { beads and } \\
\text { QDs }\end{array}$ & Chicken extract & $10^{3} \mathrm{CFU} / \mathrm{ml}$ & $\begin{array}{l}\text { QD based } \\
\text { fluorescence }\end{array}$ & $\begin{array}{l}\text { (Kim et al., } \\
2015)\end{array}$ \\
\hline S. typhimurium & $\begin{array}{l}\text { Antibody } \\
\text { immobilized in } \\
\text { microchip }\end{array}$ & & $37 \mathrm{CFU} / \mathrm{ml}$ & $\begin{array}{l}\text { QD based } \\
\text { fluorescence }\end{array}$ & $\begin{array}{l}\text { (R. Wang et } \\
\text { al., 2015) }\end{array}$ \\
\hline S. typhimurium & $\begin{array}{l}\text { Antibody } \\
\text { immobilized on } \\
\text { magnetic } \\
\text { beads }\end{array}$ & Milk & $\begin{array}{l}10 \mathrm{CFU} / \mathrm{ml} \text { in } \\
\mathrm{PBS}, \\
10^{2} \mathrm{CFU} / \mathrm{ml} \text { in } \\
\text { milk }\end{array}$ & PCR & $\begin{array}{l}\text { (Kim et al., } \\
2015)\end{array}$ \\
\hline S. typhimurium & Aptamer & Milk & $15 \mathrm{CFU} / \mathrm{ml}$ & Raman scattering & $\begin{array}{l}\text { (Duan et al., } \\
2016 \text { ) }\end{array}$ \\
\hline S. typhimurium & Aptamer & Milk & $100 \mathrm{CFU} / \mathrm{ml}$ & $\begin{array}{l}\text { Quartz crystal } \\
\text { microbalance } \\
\text { sensor }\end{array}$ & $\begin{array}{l}\text { (Ozalp et } \\
\text { al., 2015) }\end{array}$ \\
\hline C. parvum & $\begin{array}{l}\text { Antibody } \\
\text { immobilized on } \\
\text { polystyrene } \\
\text { beads }\end{array}$ & water & $1-10$ oocysts $/ \mathrm{ml}$ & Optical scattering & $\begin{array}{l}\text { (Angus et } \\
\text { al., 2012) }\end{array}$ \\
\hline B. cinerea & Antibody & $\begin{array}{l}\text { Apple (Fruit } \\
\text { extract) }\end{array}$ & $0.008 \mu \mathrm{g} / \mathrm{ml}$ & $\begin{array}{l}\text { Amperometric } \\
\text { sensor }\end{array}$ & $\begin{array}{l}\text { (Fernández- } \\
\text { Baldo et al., } \\
2010 \text { ) }\end{array}$ \\
\hline S. aureus & $\begin{array}{l}\text { Endolysin } \\
\text { (CBD plyV12) } \\
\text { immobilized } \\
\text { magnetic } \\
\text { beads }\end{array}$ & Milk & $400 \mathrm{CFU} / \mathrm{ml}$ & ELISA & $\begin{array}{l}\text { (Yu et al., } \\
2016)\end{array}$ \\
\hline $\begin{array}{l}\text { S. aureus, } \\
\text { V. }\end{array}$ & Aptamers & Milk and Shrimp & $\begin{array}{l}25 \mathrm{CFU} / \mathrm{ml} \text {, } \\
10 \mathrm{CFU} / \mathrm{ml} \text {, }\end{array}$ & Luminescence & $\begin{array}{l}\text { (Wu et al., } \\
\text { 2014) }\end{array}$ \\
\hline
\end{tabular}




\subsection{Aptamers}

Aptamers are single stranded DNA or RNA oligonucleotides of 25 to 90 bases excavated from a huge library of randomly created sequences and can form target specific structural motifs, such as stems, internal loops, purine-rich bulges, hairpin structures, pseudoknots or G-quadruplex structures (Tombelli et al., 2007). These biomolecules have drawn attention because of their unique ability of binding to a wide range of non-nucleic acid targets with high affinity and specificity. A number of remarkable advantages, such as feasibility of commercial scale up, storage stability, affinity retention and the ability to differentiate between structurally similar analytes are reported as advantages that offer great potentials to aptamers for pathogen and biomolecular screening (Torres-Chavolla and Alocilja, 2009). In the past decades, researches have extensively focused on aptamers as alternative promising bio-recognition ligands in food analysis, particularly through their integration into microfluidic sensors for multi-analytes detection of very complex food samples. Aptamers can easily be modified at their $5^{`}$ or $3^{`}$ terminus with thiols, amines or epoxy groups to facilitate their immobilization in a microfluidic chamber. For example, Yoo et al. (Yoo et al., 2015) performed a proof-of-concept study using aptamers, immobilized on a Localized Surface Plasmon Resonance (LSPR)-based sensor to detect and identify different bacterial species. In this system, the thiolated aptamers were immobilized on a multi-spot gold-capped nanoparticle array (MG-NPA) chip to recognize and capture Lactobacillus acidophilus, S. typhimurium, and Pseudomonas aeruginosa. The mixture of different bacterial species was spotted on various locations of the aptamer-functionalized sensor chip. The chip was then incubated for $1 \mathrm{~h}$ at room 
temperature before the detection process. This technique resulted in a logarithmic increase in the extinction intensity over a concentration range of $10^{9}-10^{4} \mathrm{CFU} / \mathrm{ml}$ with a detection limit of $30 \mathrm{CFU}$ of bacteria in a $3-\mu \mathrm{l}$ reaction volume.

Aptamers have been tested for their multiplexing capacity to recognize specific bacteria in real food samples, promising the possibility of their future usage in microfluidic systems. Wu et al. (2014) reported a highly specific multiplex method using aptamers as the molecular recognition elements coupled with multicolour nanoparticles as luminescence labels for efficient capturing and quantification of $S$. aureus, Vibrio parahemolyticus, and $S$. typhimurium in milk and shrimp samples with a LOD of 25,10 , and $15 \mathrm{CFU} / \mathrm{ml}$, respectively.

Despite the variety of aptamer-based strategies developed so far for food safety analysis, aptamers pose some limitations, including rapid degradation by nucleases, short duration of action, probability of interaction with other components of samples, and crossreactivity with target molecules with similar structures to their practical application. Therefore, attention to all these restrictions is essential for the development of an efficient detecting device (Lakhin et al., 2013).

\subsection{Peptide ligands}

The capability of peptides in the capturing of different bacteria highlights their potential as interesting candidates for the microbial recognition, mainly due to their broad spectrum of activity and high degree of robustness and intrinsic stability. In nature, antibacterial peptides secreted on the skin of some animals are the primary line of defence against a broad spectrum of bacteria and fungi (Boman et al., 1995). The bio-functionality of these biomolecules is dependent on their secondary structures, which are defined based on the 
amphipathic conformations. In general, cationic peptides are rich in primary amino groups and can ionically bind to the negatively charged lipids located on the bacterial membrane. In addition, extra hydrophobic interactions also take place between the cell membrane and hydrophobic compartments of the peptide (Figure 1). This concept can be applied in microfluidic devices for efficient capturing of bacteria. Magainins, polymyxins, and cecropins are examples of natural bacterial capturing peptides that can be used because of their small molecular size and intrinsic stability (Mannoor et al., 2010). Magainin I is one of the naturally occurring peptides on the skin of African clawed frogs possessing a short sequence (GIGKFLHSAGKFGKAFVGEIMKS) that can bind selectively to E. coli O157:H7. However, this peptide has also a broad-spectrum affinity toward other Gram-negative bacteria (Matsuzaki et al., 1997). Mannoor et al. (2010) have reported Magainin I functionalized microcapacitive electrode arrays for the sensitive detection of pathogenic $E$. coli and Salmonella in microfluidic flow cells. The $\mathrm{C}$ terminus of the Magainin I was first modified with cysteine residues, and then, immobilized on the gold electrodes through classical chemisorption chemistry to specifically capture and detect $E$. coli $\mathrm{O} 157: \mathrm{H} 7$ cells with a LOD of approximately 1 bacterium per $\mu$. The detection method was based on impedance spectroscopy and dielectric property of the cell membrane (Mannoor et al., 2010).

Despite the proved potential of peptides in bacterial capturing, the main drawback of these biomolecules is non-specific or semi-selective binding, which limits the use of peptides where specific recognition is required. Nevertheless, these ligands can be used in microfluidic devices with an aim to concentrate a broad range of bacterial pathogens in food matrix due to their capability to adhere on the surface of a wide range of bacterial pathogens. If specific recognition is required, particular peptide sequences can be 
synthesized and applied for capturing and detection of targeted pathogens. So far, no work showing the integration of specific peptides into the microfluidic devices has been reported and future studies are needed to explore this field.

\subsection{Carbohydrate-binding proteins and glycoprotein based ligands}

Carbohydrate-binding proteins are used much less in microfluidic platforms for capturing of bacterial pathogens in comparison to other ligands, such as antibodies, aptamers, and peptides. In this category, mannose-binding lectins (MBL), such as Concanavalin A (Con A) are the most frequently used capturing ligands owing to their broad spectrum of pathogen capturing capability. MBL recognized as the first line of defence mechanism in the host body through binding to terminal mannose and fucose residues, which are expressed on the surface of over 90 different bacteria, fungi, protozoa, and viruses. This naturally occurring phenomenon can be inspired to target and capture foodborne pathogens on microdevices. For example, a microfluidic based device combined with recombinant MBL modified magnetic beads was developed and used for detection of various pathogens, such as $C$. albicans in less than 3 hours with an extremely high sensitivity ( 1 cell/ml) (Cooper et al., 2013). A similar approach was also applied for the capturing of $S$. aureus from plasma and blood with a LOD of $10^{2} \mathrm{CFU} / \mathrm{l}$ (Kang et al., 2015). Although these systems have not been comprehensively studied in a LOC device for foodborne pathogen monitoring, the results mentioned above demonstrate the potential of such systems for this purpose.

Glycosylated proteins have also been suggested as pathogen capturing ligands. These structures possess higher stability than free peptide and proteins due to the covalent attachment of oligosaccharide chains to protein backbone (Lakhin et al., 2013). Mucins are 
a group of high molecular mass glycoproteins composed of either O-linked oligosaccharides or occasionally $N$-linked oligosaccharides as $50 \%-90 \%$ of their carbohydrates by mass (Corfield, 2015). The structure of mucins is often extended by $\mathrm{N}$ acetylgalactosamine, $\mathrm{N}$-acetylglucosamine, fucose, sialic acid, or sulphate groups to facilitate their immobilization in a microfluidic chamber (Flannery et al., 2015). Tian et al. (2010) reported the use of magnetic beads modified with porcine gastric mucin (PGM) to concentrate diverse strains of Noroviruses, including Norovirus group I and II with high capturing efficiencies of $100 \%$ and $85 \%$, respectively. This finding was further validated and confirmed in another work by Dancho et al. (2012).

\subsection{Bacteriophage endolysins}

Bacteriophages have drawn a great attention in recent years as potential ligands for foodborne pathogen detection. Bacteriophages express peptidoglycan hydrolases called endolysins at the late stage of their lytic cycle. These endolysins plays a role in the lysis of the host cell after phage replication and propagation. Generally, endolysins possesses Nterminal enzymatic activity domain (EAD) and C-terminal cell wall binding domain (CBD). Endolysins specifically target the peptidoglycan layer of bacteria where the CBD plays a role in specific host recognition and binding due to its high specificity (Kong et al., 2015). CBDs can be attractive substitute candidates of antibodies for bacterial capturing on microfluidic devices because of their smaller size (usually $10-20 \mathrm{kDa}$ ) than that of antibodies (usually $150 \mathrm{kDa}$ ) and a higher number of CBD binding sites available on bacterial cell wall (Yu et al., 2016). Various fluorescent proteins fused CBDs have been generated to specifically target and detect different Gram-positive foodborne pathogens, including L. monocytogenes, S. aureus, and B. cereus (Eugster et al., 2011; Kong and 
Ryu, 2015; Yu et al., 2016). Yu et al. (2016) performed an immunomagnetic separation study to detect $S$. aureus in milk samples with a high affinity using plyV12 CBD immobilized beads. In this work, $S$. aureus spiked milk samples were initially concentrated using antibody immobilized magnetic beads, followed by biotinylated CBD (Yu et al., 2016). The detection range was linear between $10^{3}$ and $10^{6} \mathrm{CFU} / \mathrm{ml}$ with a LOD of 400 CFU of S. aureus in the spiked milk sample within 1.5 hours. Despite all the advantages mentioned above, CBDs suffer from an inability to recognize and adhere to gram-negative bacteria, mainly due to the outer membrane of these bacteria, which shield the peptidoglycan (Figure 1). Nevertheless, the above-explained reports show a promising potential to further explore the integration of bacteriophage CBDs into microfluidic chips with the aim to generate devices for online monitoring of gram positive foodborne bacteria.

\subsection{Cardiolipin binding ligands}

There has been much interest in understanding the difference in composition of lipid domains in bacterial membranes and mammalian cells. There is evidence that the outer cell membrane of many bacteria is rich in anionic cardiolipin while it can only be found in mitochondrial membranes of mammalian cells (Epand and Epand, 2009a,b). This might open a new direction of investigation to evaluate the use of cardiolipin binding ligands not only for bio sensing but also for imaging and diagnosis applications. One of the biomolecules presenting a high cardiolipin binding affinity is apolipoprotein $\mathrm{H}(\mathrm{Apo}-\mathrm{H})$, a 38 kDa multifunctional biomolecule composed of positively charged amino acids (Borchman et al., 1995). In a recent study performed on the bacterial capturing capacity of Apo-H, Vutukuru et al. (2016) revealed that Apo-H coated magnetic beads could be used for concentrating E. coli, Enterococcus gallinarum and Candida tropicalis from $5 \mathrm{~mL}$ of blood 
samples with a LOD of $1 \mathrm{CFU} / \mathrm{ml}$. Although this is a promising achievement, the main challenge of using cardiolipin binding ligands as bacterial capturing motifs is the variation in its distribution and abundance in the cell membrane of different bacteria (Epand and Epand, 2009a), generating fluctuation in capturing efficiency between various pathogens.

\section{Sample preparation in microfluidic devices}

In general, it is impossible or challenging to detect food borne pathogens directly from food samples by exposing untreated food samples to diagnostic biomarkers without proper sample preparation steps. Many pathogens are present in a very low concentration in food samples. Therefore, enrichment of targeted analytes or cells is of high importance for detection purposes (Atalay et al., 2011; Buldini et al., 2002). A number of microfluidic platforms, based on different principles, have been reported to cope with the complexity of sample preparation and enrichment (Foudeh et al., 2012; Mairhofer et al., 2009; Velusamy et al., 2010; Zaytseva et al., 2005). However, this challenge is not addressed for highly sensitive and accurate detection of microorganisms in food matrices. In this section, we will comprehensively elaborate recent advances in microfluidic-based sample preparation techniques to elucidate the prominent potential of such systems in foodborne pathogen detection.

\subsection{Microbeads and porous membranes}

Micro-sized iron oxide magnetic particles are widely applied in microfluidic devices to increase the chance of pathogen bio-recognition due to their high surface-to-volume ratio. The most popular strategy for magnetic bead-based sample preparation is simple mixing of the capturing ligand-functionalized beads with the contaminated food samples. This 
results in attachment of pathogens to the beads, followed by pathogen enrichment and collection using a magnetic field (Bu et al., 2008; Ikeda et al., 2006; Sasso et al., 2012). Antibodies are the most recognized motifs that have been intensively used for functionalization of magnetic particles to separate bacteria from food matrices (Lim and Zhang, 2007; $\mathrm{Ng}$ et al., 2010). After the bacterial enrichment step, fluorescent molecules or quantum dots can be used to label captured bacteria and quantitatively discriminate bacteria-magnetic bead complexes from magnetic beads without bacteria (Gao et al., 2006; J. J. Lee et al., 2014). Size-based separation of free magnetic nanoparticles from bacteria-magnetic nanoparticle complexes using filter membranes is also suggested to skip complicated labelling procedures (Shim et al., 2014). Both methods can be combined with microfluidic devices to concentrate target microorganisms or cells, although low sensitivity has remained a challenge. Other microfluidic separation methods, such as surface acoustic waves, deterministic lateral displacement and inertial focusing have been explored to develop highly efficient sample separation methods. Lee et al. (2015) have shown efficient separation of free magnetic beads from $E$. coli bacteria-magnetic bead complexes by inertial focusing method based on Dean drag force and in the presence of a sheath flow in a microfluidic device. The antibody functionalized magnetic beads were used to capture E. coli bacteria in milk. In the next step, a 3D-printed helical microchannel was used to separate free magnetic beads from E. coli-magnetic bead complexes using inertial focusing method as illustrated schematically in Figure $2 \mathrm{~A}$. By this method, it is feasible to reduce the physical damage of cells during separation and to control the operating condition with no external force. In addition, contrary to spiral channels used on a flat surface (Martel and Toner, 2012), the 3D-printed helical microchannel has a constant radius of curvature and Dean number that can facile the prediction of the flow behaviour 
and separate pathogens from the mixture in a controllable manner. Combination of this technology with UV-vis absorption spectroscopy could detect $10 \mathrm{CFU} / \mathrm{ml}$ and $100 \mathrm{CFU} / \mathrm{ml}$ of bacteria in buffer and milk, respectively.

In another work (Lee et al., 2014), a 3D-printed microfluidic device was used for immunomagnetic flow assay and rapid detection of pathogenic bacteria in large-volume food samples. As illustrated schematically in Figure 2B, antibody-functionalized magnetic nanoclusters were magnetically immobilized on the surfaces of a 3D-printed microchannel by a strong magnet located inside the hollow space of a cylinder. The high flow rate injection of a Salmonella-spiked sample solution into the microchannel resulted in rapid binding between the antibody-functionalized magnetic nanoclusters and Salmonella due to their high affinity. After a washing step, the magnet was removed, and the bacteria flushed out and collected, resulting in a LOD of $10 \mathrm{CFU} / \mathrm{ml}$. This study is one of the exceptional achievements for ultrafast detection of foodborne pathogens in microfluidic devices since a 3 min-procedure is enough for binding, washing, and detection of targets in a $10 \mathrm{ml}-$ sample. 


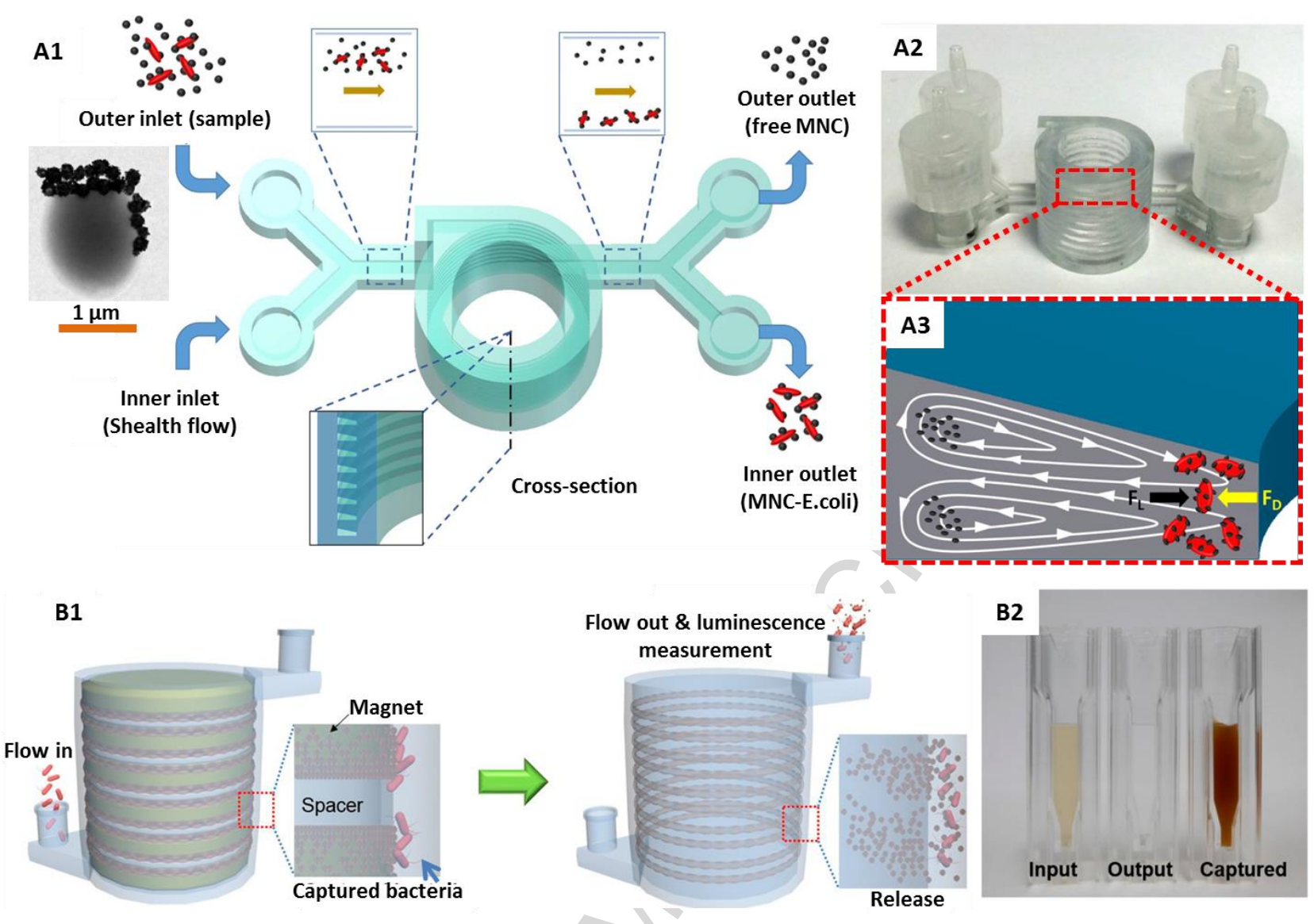

Figure 2. (A1) Schematic illustration of the device used to separate captured bacteria by inertial focusing and (A2) photographic image of the 3D printed device. (A3) Illustration of Dean vortices in a channel with trapezoid cross-section. Sample solution containing free magnetic beads and magnetic bead-bacteria complexes is injected into the outer inlet while a sheath flow is injected into the inner inlet of the device. This results in the generation of Dean vortices and separation of free bacteria from the ones complexed with the beads when the fluid passes through the curved microchannel. The fabricated device incorporated 10 loops of the helical microchannel to provide sufficient length needed for particle migration. Reprinted with permission from Ref. (Lee et al., 2015), copyright 2015 Nature Publishing Group. (B1) Schematic representation of 3D immunomagnetic flow assay. The magnet was placed in the hollow centre of the device during the capture and rinsing of the antibody functionalized magnetic bead-Salmonella complexes. The magnet was then removed from the device and bead-bacteria complex was collected using a disposable syringe. Reprinted with permission from Ref. (Lee et al., 2014), copyright 2014 American Chemical Society publications.

Immunomagnetic separation followed by pathogen labelling using QDs or fluorescent nanoparticles in a microfluidic device is recognized as a rapid and sensitive quantitative detection approach for foodborne pathogens. Kim et al. (2015) have used anti-Salmonella 
antibody-coated superparamagnetic beads to concentrate $S$. typhimurium cells for rapid sensing in a microfluidic device when anti-Salmonella polyclonal antibody-conjugated QDs was used to form a "sandwich" complex with the bead-cell conjugates. The bacteria were separated at room temperature after mixing with the magnetic beads for $30 \mathrm{~min}$. After sample enrichment and washing, the captured cells and antibody-conjugated QDs were injected into two different inlets of the microfluidic device. The two solutions were then mixed in the meandering channel, and the cells were labelled with the antibody-conjugated QDs (Figure 3A). Next, the QD-labelled cells were concentrated in the detection zone using an external magnetic field introduced by a permanent magnet placed in the detection zone of the microfluidic chip. The unbounded QDs were washed away using borate buffer injected into the inlet, and the microfluidic chip was then inserted into the portable fluorimeter for measurement. Using this system, a LOD of $10^{3} \mathrm{CFU} / \mathrm{ml}$ of Salmonella in the chicken extract was archived (Kim et al., 2015). 

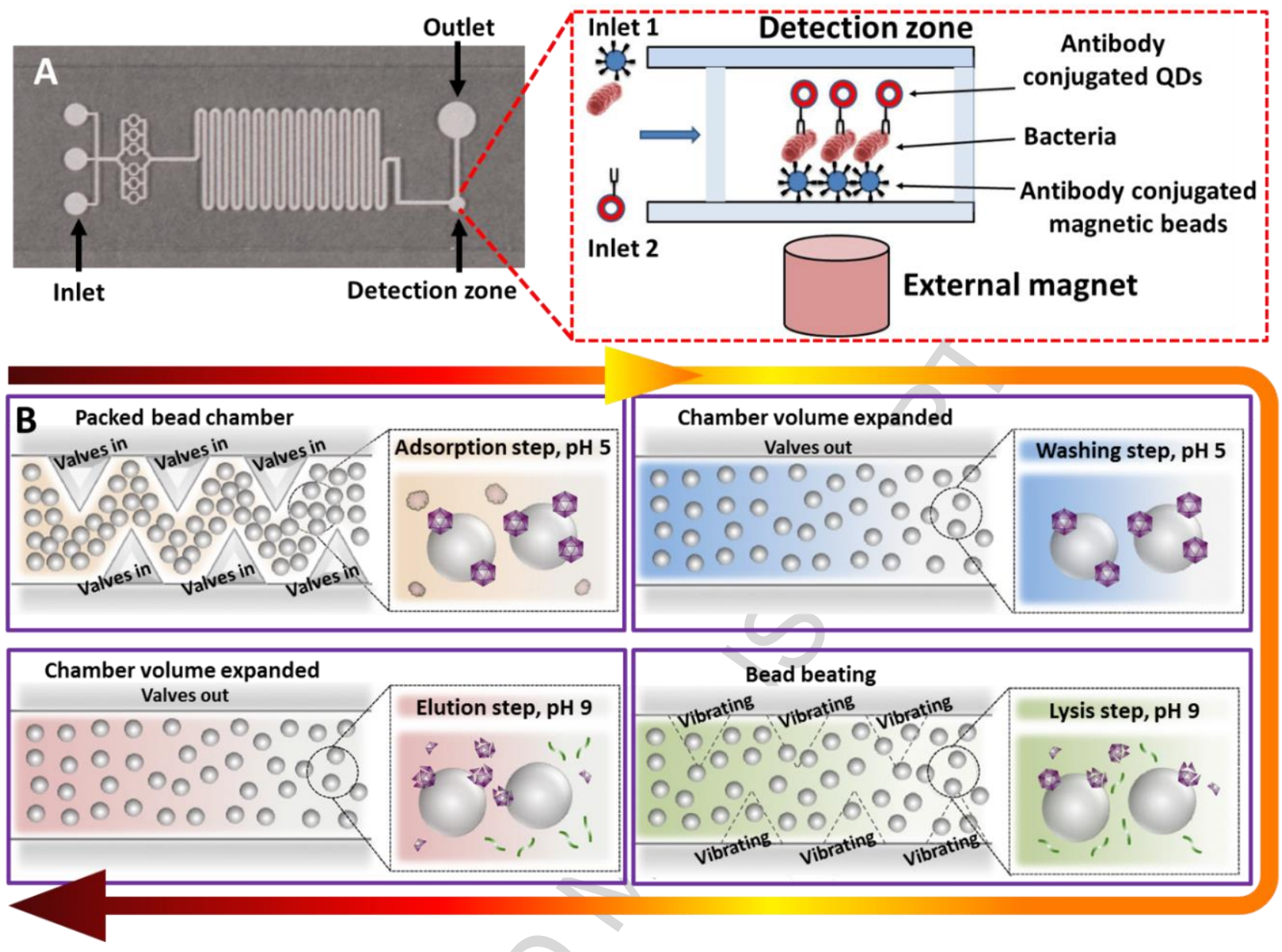

Figure 3. (A) The layout of the microfluidic design and schematic illustration of the detection zone, where the QDs tethered to the bacteria-bead complex can be quantitatively detected by a fluorimeter. Reprinted with permission from Ref. (Kim et al., 2015), 2015 copyright Elsevier B.V. (B) Schematic demonstration of whole detection processes of murine norovirus by microfluidic chip module. Reprinted with permission from Ref. (Chung et al., 2015), 2015 copyright Elsevier B.V.

While the literature includes several examples of bacterial pathogen detection in food samples using bead mediated microfluidic devices, such methods are not fully examined for the detection of viral pathogens due to the limitations associated with the sample preparation of viruses. Attention has slowly been shifting towards this challenge thanks to the development of miniaturized microfluidic chips as interdisciplinary technologies for diagnostic applications. For example, Chung et al. (2015) developed a novel microfluidic device for the detection of murine norovirus in oysters by charge switchable micro-bead 
beating technology (Figure 3B). In this system, several steps were integrated within a chip to detect norovirus in food samples. First, the chopped oyster and buffer mixture were loaded into a chamber containing packed charge switchable microbeads for the adsorption of Norovirus to the beads by electrostatic interaction. After washing step, all the adsorbed viruses were effectively lysed by applying vibration mediated bead beating. The released RNA virus was then extracted and transferred to another chamber by syringe pump system for reverse transcriptase amplification. The use of microbeads for both sample concentration and lysis resulted in an efficient recovery of over $60 \%$ of murine norovirus RNA in oyster samples with a LOD of $10^{2} \mathrm{CFU} /$ single oyster in 4 hours.

In addition to the microfluidic devices integrated with magnetic beads, filters and membranes are the other straightforward and cost-effective alternatives for the rapid concentrating of targeted pathogens, particularly for very large volume samples. For example, Dharmasiri et al. (2010) reported the use of a microfluidic system with integrated polycarbonate-based filters to physically enrich $E$. coli bacteria up to $2 \times 10^{2}$-fold. One of the main potentials of the filters is the possibility to chemically functionalize their surface for selective capturing of foodborne pathogens. Tan et al. (2011) described a PDMS microfluidic immunosensor, fabricated by a simple micro-fabrication process, for efficient detection of $S$. aureus and $E$. coli O157:H7 using antibody immobilized nanoporous alumina membrane integrated into the device. The antibody was covalently immobilized on nanoporous alumina membrane using (3-glycidoxypropyl) trimethoxysilane (GPMS) silane monolayer as cross linker (Figure 4A). The membrane had $13 \mathrm{~mm}$ diameter and a thickness of $60 \mu \mathrm{m}$. The membrane was integrated between two oxygen plasma treated PDMS layers, and a platinum wire electrode was used for impedance sensing (Figure 4B). The sample containing bacteria was loaded into the upper compartment where antibodies 
tethered on the nanoporous alumina membrane were able to capture pathogens. This resulted in the blockage of electrolyte current through the membrane and consequently led to an increase in impedance, which was detectable in the impedance spectrum (Figure 4C). This microfluidic immunosensor device could rapidly detect bacteria within 2 hours with a LOD of $10^{2} \mathrm{CFU} / \mathrm{ml}$, showing more desirable sensitivity in comparison to traditional microelectrode based impedance sensors. Overall, the membrane assisted sample enrichment in microfluidic systems are still in an infancy state, and therefore, extra efforts are needed to investigate new concepts that can be practically applied to design such miniaturized sensing devices.
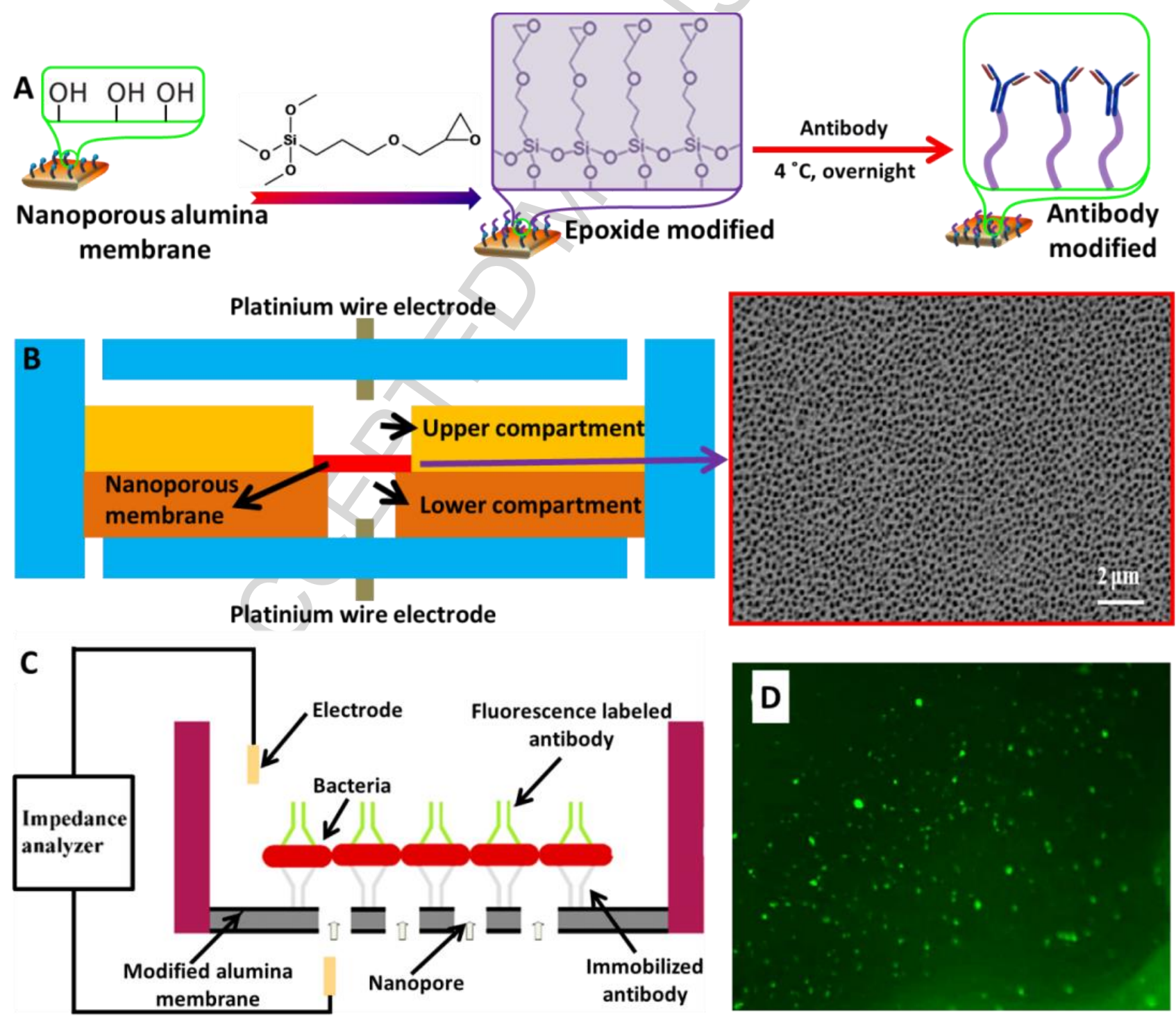
Figure 4. (A) Immobilization of antibodies on nanoporous alumina membrane. The membranes were first treated with a $10 \%$ hydrogen peroxide $\left(\mathrm{H}_{2} \mathrm{O}_{2}\right)$ to remove any contaminants and generate reactive hydroxyl group on the surface. After drying, toluene solution with 1\% GPMS was applied overnight to functionalize the surface with epoxide groups. Next, the antibody was immobilized on the surface through the reaction of the amine groups on antibody with the epoxy groups on the surface of the membrane. (B) Schematic illustration of the PDMS microfluidic device integrated with nanoporous alumina membrane and SEM image of the porous membrane. (C) The mechanism of impedance sensing via antibody immobilized on nanoporous alumina membrane. The pathogen will anchor to complimentary antibodies on the modified nanoporous alumina membrane, once the sample with target bacteria loads into the upper compartment. When bacteria are captured on the membrane, the nanopores will be blocked, and subsequently, the electrolyte current through the membrane will decrease and can be observed in the impedance spectrum. (D) Fluorescence image of $S$. aureus captured on antibody modified membrane with a concentration of $1 \times 10^{5} \mathrm{CFU} / \mathrm{ml}$. Reprinted with permission from Ref. (Tan et al., 2011), 2011 copyright Elsevier B.V.

\subsection{Continuous-flow sample-preparation methods}

Although magnetic bead assisted enrichment of pathogens in microfluidic devices allows quick and robust detection of the pathogens in food matrices, this technique suffers from some drawbacks related to the pre-processing necessity, loss of beads in matrices with fatty components and the high cost of the beads (Jenïkovâ et al., 2000; Li et al., 2013). To address these challenges, continuous flow separation methods in microfluidic devices have been introduced to allow cheap, fast, and reliable sample separation and processing (Hejazian et al., 2015; Lee et al., 2012; Lenshof and Laurell, 2010). Acoustophoresis, magnetophoresis, and dielectrophoresis are the main methods investigated for continuous flow sample separation (Abdallah et al., 2015; Ngamsom et al., 2016a; Zhang et al., 2010). Acoustophoresis mediated cell separation in the microfluidic devices allows gentle pathogen concentration without any labelling and only based on the difference of their size, density, and compressibility compared to the surrounding medium (Ngamsom et al., 2016b). The principle of acoustophoresis is based on the exertion of radiation force on suspended cells in the presence of a resonant acoustic field (Abdallah et 
al., 2015; Ngamsom et al., 2016b). Acoustic radiation force on a cell or particles can highly change with a small change of their size, facilitating the size dependent fractionation of different components of a sample (González et al., 2010). This will result in a faster transfer of bigger sized components to the pressure node located in the centre of the flow channel. This concept has been applied to separate foodborne pathogens by designing microfluidic devices with multiple outlet branches, and adjusting the acoustic power so that the pathogens reach the centre of the column before the flow split. Ngamsom et al. (2016b) fabricated an acoustophoresis based pre-analytical technique to collect foodborne pathogens on a chip. The device was composed of three inlets, a central channel for sample separation and three outlets (Figure 5). The sample was injected from the side inlets, and buffer solution was loaded through the central inlet. By applying ultrasound actuation, pathogenic cells could remain near the wall corner of the channel while the large debris particles $(10-100 \mu \mathrm{m})$ of meat samples were continuously fractionated into the centre of the flow channel. This system was used to detect $S$. typhimurium in chicken and minced beef with successful recovery (60-90\%) of ca. $10^{3} \mathrm{CFU} / \mathrm{ml}$. 


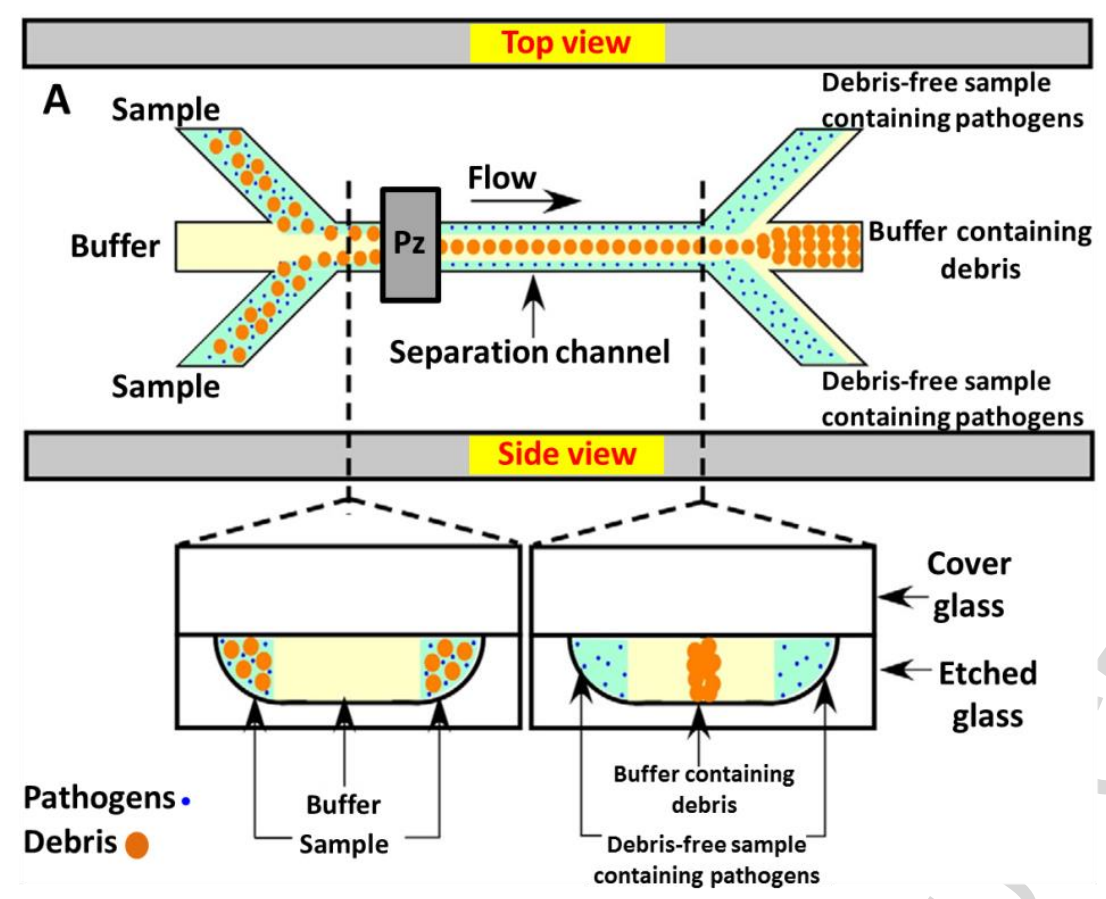

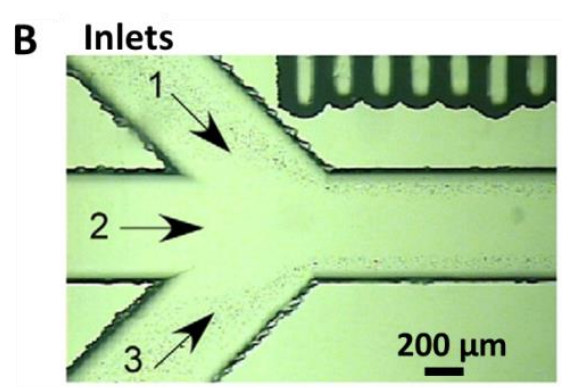

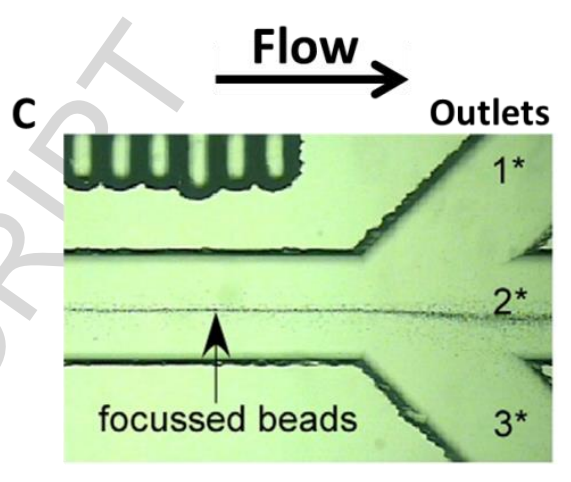

Figure 5. (A) Schematic illustration of the acoustophoresis based microfluidic device for the collection and separation of pathogens under ultrasonic radiation force. Debris particles move to the pressure nodal plane in the central outlet containing the buffer stream, whilst the microbial cells remain in the sample streams exiting the side outlets. A piezo-ceramic transducer $(\mathrm{Pz})$ is assembled in the centre of the channel to generate ultrasonic wave and acoustic radiation forces. Large debris experience bigger force and move into the central buffer stream, while less acoustic radiation force on microbial cells allows their collection from side outlets. Section B and C show a microscopic photograph of characterization and optimization of acoustophoresis process using polystyrene beads. The inlets and part of the separation channel are shown in section B. The outlets and part of the separation channel is shown in section $\mathrm{C}$. The side inlets were used to introduce the beads into the separation channels. The beads remain in the outer part of the separation channel under the laminar flow regime (B). Upon ultrasonic actuation, the beads move to the centre of the separation channel due to the generated acoustic force and can be collected from the central outlet (C). Reprinted with permission from Ref. (Ngamsom et al., 2016b), 2016 copyright Elsevier B.V.

Magnetophoresis is another technique that can be applied for continuous flow sample separation in microfluidic devices using external magnetic fields (Ngamsom et al., 2016a). In contrast to immunomagnetic separation where simultaneous sorting of different pathogens are very challenging, free-flow magnetophoresis can separate pathogenmagnetic bead complexes based on the differences in their sizes and magnetic power by 
varying their deflection from the straight direction of laminar flow. This method has attracted lots of attention for continuous sorting of magnetic beads from nonmagnetic components or two different magnetic beads from each other (Krishnan et al., 2009; Pamme et al., 2006). However, the potential of this strategy for sorting and analysis of foodborne pathogen has not been explored intensively despite its capability for automated sample separation. Combining magnetophoresis techniques with immunomagnetic separation might be the future direction towards high throughput concentrating of target pathogens from complex food samples. Ngamson et al. (Ngamsom et al., 2016a) have applied this combination for rapid enrichment, sorting and detection of viable $S$. typhimurium and E. coli $\mathrm{O} 157$ from food samples. The pathogen specific magnetic beads with different sizes and magnetite contents were utilized for the capturing and concentrating of viable S. typhimurium and E. coli O157:H7. Two different types of beads were used to specifically capture and separate different bacteria by means of an inhomogeneous magnetic field applied perpendicularly ( $y$-direction) to the direction of the flow. Depending on the size of the beads and the quantity of magnetic materials, different extent of bead deflection from the flow direction takes place within the chip (Figure 6). Figure $6 \mathrm{~B}$ shows the design of the polymethyl methacrylate chip. The importance of the flow rate and magnetic power optimization for magnetophoresis based pathogen separation has also been addressed and examined (Figure 6C). It was shown that, in addition to the flow rate dependent cell deflection, a less iron oxide content would result in a lower magnetic bead deflection, an exploited concept to enrich more than one pathogen from a food sample. 

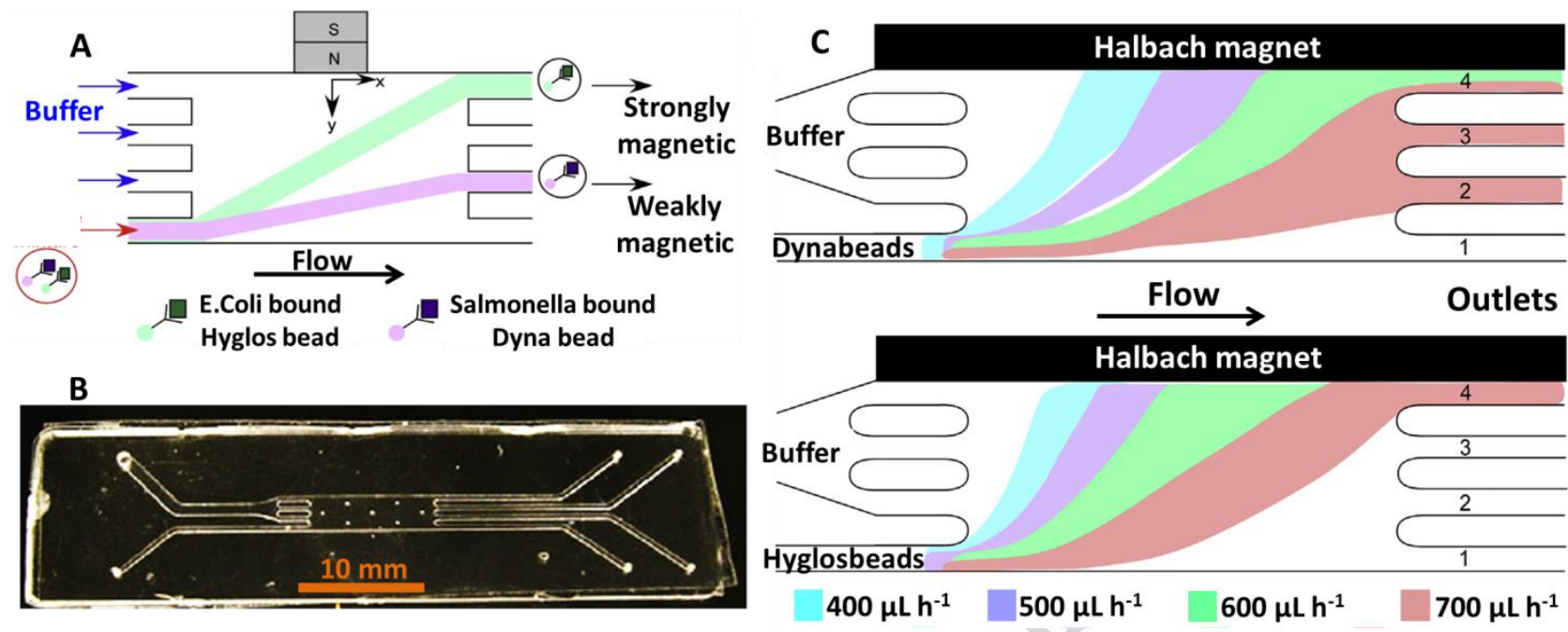

Figure 6. (A) Principle of multiplex sorting of two different types of pathogen-bound magnetic beads by free-flow magnetophoresis and (B) the photograph of polymethyl methacrylate chip. (C) Deflection of anti-salmonella Dynabeads and anti-E. coli Hyglos beads as a function of the flow rates of the bead. It was revealed that lower flow rates result in a bigger deflection of magnetic beads. In addition, at the same flow rate, Dynabeads showed less deflection compared to Hyglosbeads due to the less iron oxide content and lower magnetic properties. Reprinted with permission from Ref. (Ngamsom et al., 2016a), 2016 copyright Elsevier B.V.

Guo et al. (2015) combined stationary magnetic trap and dynamic magnetophoretic separation techniques to separate and detect foodborne pathogens at very low concentration. They were able to precisely control the flow direction of magnetic beads in a magnetophoretic microfluidic device through the manipulation of the magnetic force against the hydrodynamic force. This resulted in simultaneous sample enrichment and separation in the microfluidic device. As indicated in Figure 7, the device consists of an upper layer of microfluidic channels formed by PDMS, ITO glass with micro-fabricated nickel wires and nickel patterns as the bottom layer, and a thin PDMS film as the middle layer to encapsulate the nickel structures. The nickel wires act as magnetophoretic separation zone while the nickel patterns are applied in the device as the detection zone. The S. typhimurium-magnetic particle complexes were separated from free E. coli bacteria and other components of the sample by passing through the area covered by micro- 
fabricated nickel wires. Next, the bacterial cells were trapped into the nickel-pattern detection zone, where a sandwich immunoassay based on biotin-antibody and streptavidin modified QDs (SA-QDs) was used to identify the bacteria. The use of this combined approach resulted in a LOD of $5.4 \times 10^{3} \mathrm{CFU} / \mathrm{ml}$ in milk. Compared to a similar device composed of only stationary magnetic trap, the fluorescence intensity of the detected signals are higher in the integrated device, enabling accurate detection of pathogens in complex samples. Since foodborne pathogens usually exist at a very low concentration in food matrices at initial stages, combining different technologies similar to the one described above is essential to achieve a higher sensitivity in microfluidic devices. In general, the integration of magnetophoresis technology into the sensing devices is very beneficial since the magnetic beads are known as powerful tools for sample concentration due to their large surface-to-volume ratio as well as flexible functionalization, while rendering the possibility to skip tedious washing process and purification of captured pathogens. 

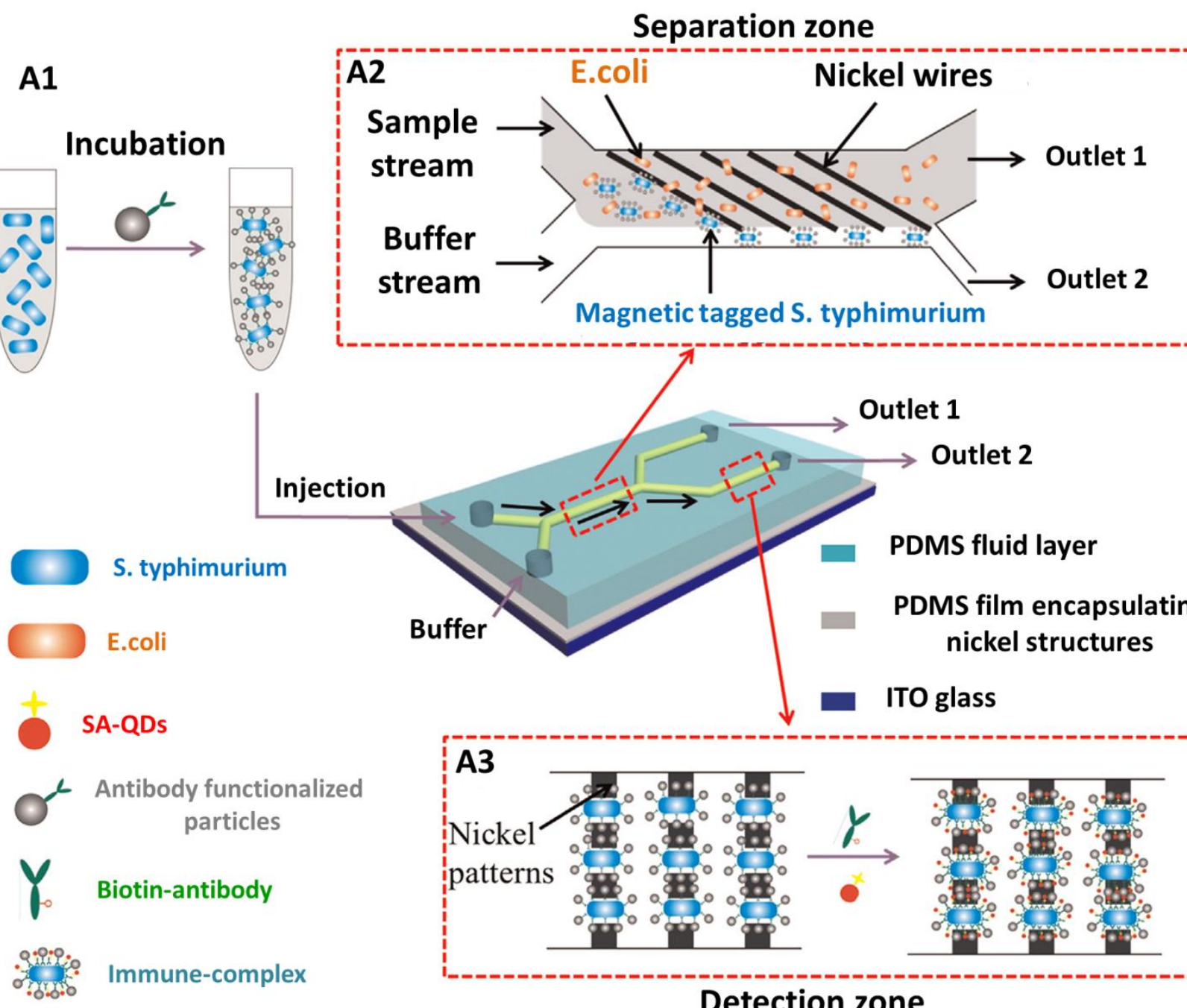
then injected to an integrated chip in which two pairs of magnets were separately placed under the magnetophoretic separation zone (A2) and magnetic trap zones (A3; detection zone). (B1) Fluorescence images are taken from four different parts of the separation zone (E. coli in red and S. typhimurium in blue colour). The separation of the blue magnetic tagged S. typhimurium is observable in outlet 2 while E. coli could be collected in outlet 1 . (B2) Fluorescence microscopic images of sample collected before and after separation (outlet 1 and 2). (C) Comparison of the capturing capability in milk samples for the magnetophoretic integrated device and the device with magnetic trap alone. Reprinted with permission from Ref. (Guo et al., 2015), 2015 copyright Elsevier B.V.

\section{On-chip techniques for rapid foodborne pathogen detection}

Conventional bacterial culture methods for the counting of colony forming unit (CFU) provide visual confirmation of microbial growth on a solid nutrient medium. This approach is simple and easily adaptable. However, it is laborious, time-consuming (1-6 days), and requires special equipment (i.e., incubator with special atmosphere and temperatures) as well as various microbial specific culture media for selective pre-enrichment and plating. Therefore, other alternatives, such as electrochemical, immunological and nucleic acid based methods with broad spectrum of applicability are proposed to detect foodborne pathogens in foods. All these methods often face a major intrinsic problem associated with the complexity of food matrix. For example, inhibition of PCR has been observed when exposed to carbohydrates, high salt or fat concentration, sucrose, lysine and some polyphenolic compounds which may bind to nucleic acid templates or interfere with DNA polymerase activity (Adami et al., 2016; Dwivedi and Jaykus, 2011). Enzymes or other antimicrobial components and by-products released during food processing and sample pre-treatments (e.g., homogenization or blending) may also interfere with the outcome of the detection methods (Bhunia, 2014; Sharma and Mutharasan, 2013). Therefore, when developing a new detection technique, attention to possible interferences with any step of the on chip sample preparation must be taken into account. In this section, the most relevant, appropriate and practical biosensing methods, as well as immunological and 
nucleic acid based strategies for rapid detection of foodborne pathogens will be discussed in detail.

\subsection{Surface plasmon resonance biosensors}

Surface plasmon resonance (SPR) is the fundamental principle behind many colourbased or lab-on-a-chip sensors by measuring the adsorption of materials onto metal surfaces. SPR technologies (Nguyen et al., 2015; Tokel et al., 2014) that uses a planar thin gold film or metal nanostructures with surface plasmon modes at the structural interface have been widely exploited to detect bacteria, viruses, nucleic acids, proteins, drugs, and in monitoring of biomolecular interactions (e.g., nucleic acid hybridization or protein-ligand interaction) (Mayer et al., 2011; Nguyen et al., 2015; Tokel et al., 2014; Unser et al., 2015; Wang et al., 2012). Conventional SPR biosensors, which apply reflectance spectroscopy, are of interest for the detection of foodborne pathogens (Velusamy et al., 2010). In these biosensors, the capturing ligands are often immobilized on the surface of thin metal where the electromagnetic radiation of certain wavelength will interact with the electron cloud of the thin metal layer to produce a strong resonance. The capturing of pathogens on the surface will change the refractive index of the metal surface and result in the change of wavelength for electron resonance (Zhang, 2013; Zhao et al., 2014). With a number of advantages, such as label-free, sensitive, and real-time capacity, SPR sensors have advantages over other conventional techniques, such as fluorescence and isotope labelling. This is the main reason for the wide exploitation of this technique in disease monitoring, diagnostics, homeland security, food safety, and biological imaging (Wittenberg et al., 2014). Commercial SPR sensors, such as SPREETA and BIACORE 3000 biosensors are currently utilized for the detection of E. coli O157:H7, Salmonella 
enteritidis (S. enteritidis), S. typhimurium, and Listeria monocytogenes in food samples with a LOD of $10^{2}-10^{5} \mathrm{CFU} / \mathrm{ml}$ (Stephen Inbaraj and Chen, 2016). By combining recent advances in plasmonic technologies with cutting-edge nanotechnologies, a new generation of SPR biosensors with superior sensitivity, multiplexing capability, and quantification capability are developed for detection of a variety of pathogens, such as $E$. coli 0157:H7, Campylobacter jejuni, P. aeruginosa, S. typhimurium, and methicillinresistant S. aureus (MRSA) (Singh et al., 2011; Tawil et al., 2013, 2012; Torun et al., 2012; Wan et al., 2014; Wang et al., 2012). Despite all these efforts, the development of simple, cost-effective, portable, and easy-to-use SPR based POC platforms are still in an early stage, and there is a demand for miniaturization of the SPR based system suitable for onsite testing without using relatively large equipment. Therefore, the efforts are now focused on the integration of SPR biosensors into microfluidic devices (Wang and Fan, 2016). Zordan et al. (2009) reported a hybrid SPR microfluidic chip that has successfully been developed for the detection of E. coli O157:H7. A SPRi apparatus (GenOptic, France), which was equipped with an $800 \mathrm{~nm}$ light-emitting diode (LED) source, a charge-coupled device (CCD) camera, and a microfluidic cell, was able to identify $16 S$ rRNA sequence of Legionella peneumophila with a detection limit of $0.45 \mathrm{fM}$ (Foudeh et al., 2014). Despite all these advances, both these SPR systems are still very complex and far from the POC stage. With an aim to miniaturize the SPR integrated microfluidic systems, Coskun et al. (2014) developed a portable lightweight (40 grams with $8.8 \mathrm{~cm}$ in height) microfluidic SPR device (Figure 8A) that contains a complementary metal-oxide-semiconductor (CMOS) sensor instead of a CCD camera to enable real-time and label-free monitoring of biomolecular interactions. Cappi et al. (2015) developed a system based on transmission configuration using a wide emission spectrum white light LED and a CMOS detector 
camera incorporating with a simple two channel microfluidics (Figure 8B) for real-time detection purposes. Combining this system with specific aptamers as bioreceptors resulted in a LOD of $0.5 \mu \mathrm{M}$. Although both platforms described above are still at proof-of-concept stage and are not applied for pathogen detection, they are good examples of simple, costeffective, and sensitive platforms with the potential to be employed as POC devices for rapid online pathogen detection in food samples in a near future. Tokel et al. (2015) reported a multiplex cost-effective microfluidic-integrated SPR device (Figure 8C) for detection and quantification of $E$. coli and $S$. aureus with a LOD of $10^{5}$ and $3.2 \times 10^{7}$ CFU/ml in spiked phosphate buffered saline and peritoneal dialysis fluid, respectively. In this system, specific antibodies for capturing of E. coli (anti-lipopolysaccharide/anti-LPS) and S. aureus (anti-lipotheichoic acid/anti-LAT) were utilized to functionalize the disposable microfluidic chips with gold coated surface through several activators, including, 11-mercaptoundeconoic acid (MUA), N-(3-Dimethylaminopropyl)-N'ethylcarbodiimide Hydrochloride (EDC), N-Hydroxysuccinimide (NHS) and protein G. When the bacteria is captured on the gold-coated surface of the microchannel, a signature on the reflected light will be generated via a change in the local refractive index, which will be detected by the CMOS sensor and transferred to a computer for analysis.

In summary, all the systems mentioned above are still at the research stage and not commercialized yet. However, the results indicate a possibility to generate a portable, specific, and sensitive POC device for rapid on-site detection of foodborne pathogens. The integration of SPR sensors in micro-chambers connected with multiple microchannels in the flow-through microfluidic systems can pose a high-throughput SPR imaging sensor for multiplexed on-site testing of different targets (P. Chen et al., 2015; Im et al., 2014; Inci et al., 2015). However, due to the complexity of food sample as well as the very low 
concentration of pathogens in the food, the sample preparation techniques described in section 3 are crucial for subsequent high-quality SPR sensing of foodborne pathogens. There is, though, a long road ahead for this emerging technology to be fully adapted to microfluidic-integrated SPR sensors devices for analytical performance. 
A
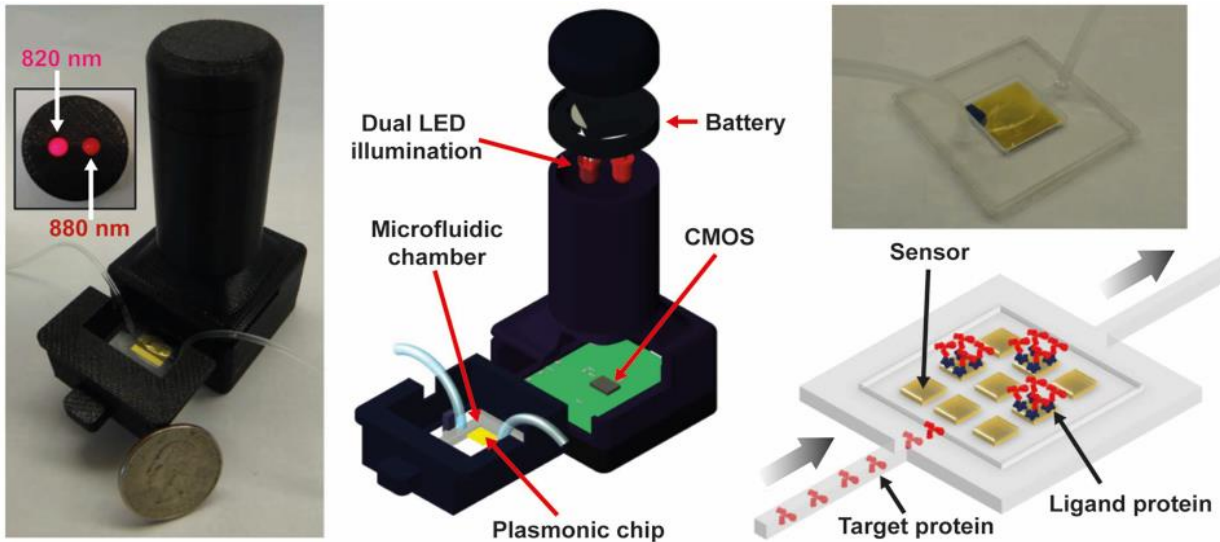

B
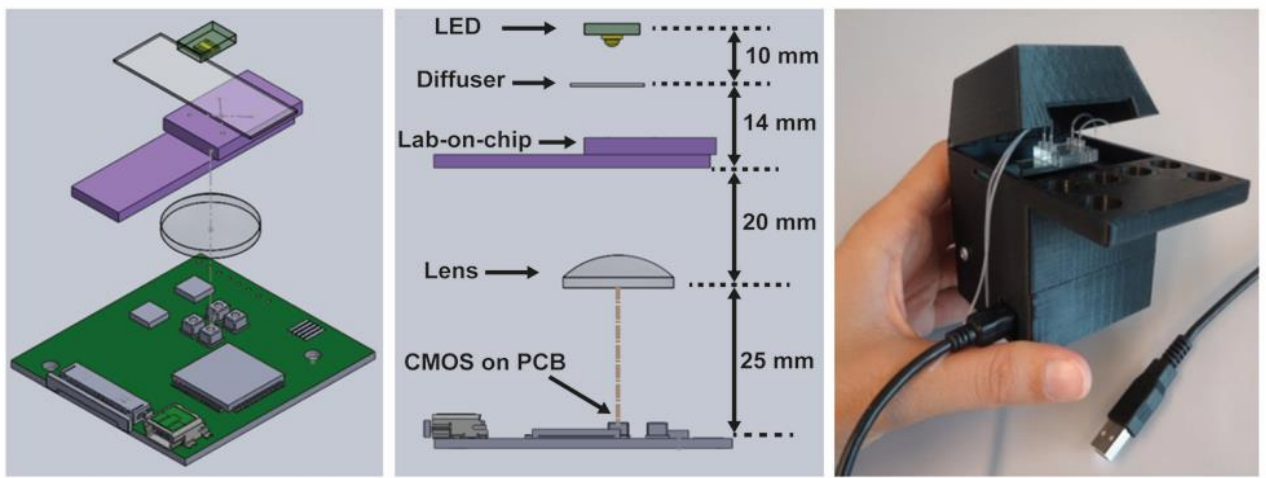

C

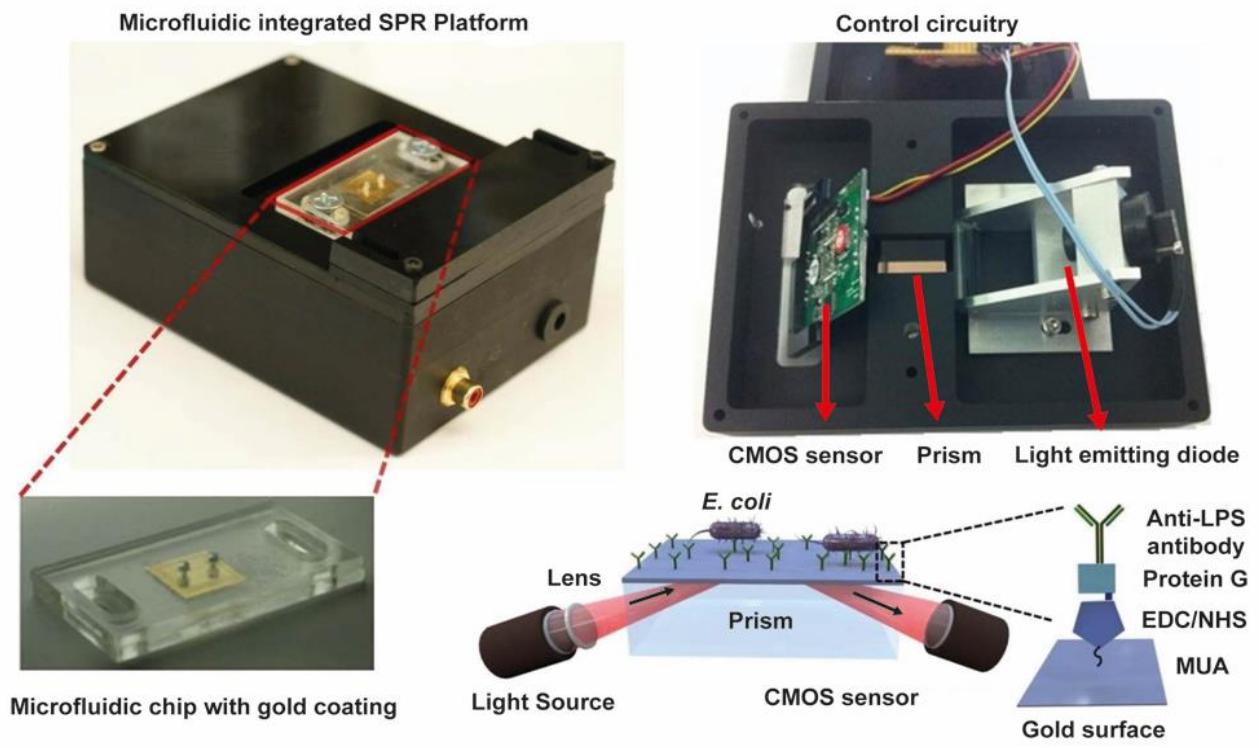


Figure 8. Demonstrations of SPR-based integrated microfluidic devices. (A) Representation of plasmonic biosensor platform integrated microfluidics onto nanohole arrays. Reprinted with permission from Ref. (Coskun et al., 2014), copyright 2015 Macmilllan Publishers Ltd. (B) Illustration of a complete custom-made transmission-LSPR setup combining the digital rendering of the components and their relative distances. Reprinted with permission from (Cappi et al., 2015), copyright 2015 American Chemical Society. (C) A scheme of all the components in a portable plasmonic device for detection and quantification of the bacterial pathogen and a SPR integrated microfluidic platform. The disposable microfluidic chip with the functionalization of the gold-coated surface is placed on the rectangular prism and mounted on the top side of the device. The electronic setup of the device including LED source and CMOS sensor is represented from the bottom. Reprinted with permission from Ref. (Tokel et al., 2015), copyright 2015 Macmilllan Publishers Ltd.

\subsection{Optical fibre biosensors}

Optical fibre biosensors have been widely exploited for the detection of a board range of analytical targets, including viruses, spores, bacterial pathogens, pesticides, toxins and other small molecules from clinical and food samples (Bhunia, 2014; Bosch et al., 2007; Liu et al., 2014; Marazuela and Moreno-Bondi, 2002; Urrutia et al., 2015; Velusamy et al., 2010; Wang et al., 2009). The working principle of the optical fibre biosensors and their applications are well known and have been extensively reviewed (Bosch et al., 2007; Chen and Ding, 2013; Marazuela and Moreno-Bondi, 2002; Wang and Wolfbeis, 2016, 2013). One of the approaches pursued in the last decade is the combination of optical fibre biosensors with various spectroscopic techniques such as absorption, fluorescence,

Raman, SPR, etc., for detection of foodborne pathogens (Demarco, D.R. and Lim, 2002; Ko and Grant, 2006; Liu et al., 2003; Ohk and Bhunia, 2012; Sharma and Mutharasan, 2013). At present, the focus is shifting towards the integration of SPR into microfluidic systems to establish versatile lab-on-fibre technology for the POC applications (Blue and Uttamchandani, 2016; Chen et al., 2016; Lin et al., 2015; Luka et al., 2015; Oscar et al., 2017; Ricciardi et al., 2015; Sun et al., 2016; M. Yin et al., 2016). For instance, two portable devices with microfluidic setup (Analyte $2000^{\mathrm{TM}}$ and RAPTOR ${ }^{\mathrm{TM}}$ ) are 
commercially developed for the detection of Salmonella spp., Bacillus anthracis, Francisella tularensis, Listeria monocytogenes, and E. coli O157:H7 from various food matrices with a LOD ranging from $10^{2}$ to $10^{4} \mathrm{CFU} / \mathrm{ml}$ (Bhunia, 2014; Ohk and Bhunia, 2012; Sharma and Mutharasan, 2013; Valadez et al., 2009). Recently, Gauri et al. (2017) designed a fibre optic microchannel biosensor for ultra-rapid UV-Vis based detection of Aeromonas hydrophila in less than 10 min using a total sample volume of $3 \mu$ l. The fibre optic was used to transmit and receive the light signals for detection and identification of the pathogen. Similar concept was applied for rapid detection of $E$. coli in less than 10 min with an LOD of $1 \times 10^{2}$ cells/ml (Abidin, Z. Z., Gauri, S., Mahdi, M. A., Yunus, 2016).

The combination of optical fibre biosensors with Raman spectroscopic techniques for ultra-sensitive detection of foodborne pathogens is growing very rapidly (Walter et al., 2011;; Sengupta et al., 2012; Craig et al., 2013; Xie et al., 2013; Stöckel et al., 2016;; C. Wang et al., 2017;) since Raman spectra can provide a broad range of information about the chemical composition of the structure of biomolecules within the microorganisms (Stöckel et al., 2016). A number of studies have demonstrated that surface-enhanced Raman spectroscopy (SERS) coupled with metallic (e.g., silver or gold) nanoparticles can perform ultra-rapid and sensitive detection of foodborne pathogenic microorganisms including E. coli 0157:H7, S. aureus, Salmonella spp, Shigella spp, Listeria monocytogenes, Enterococcus faecelis, Bacillus spp, and Enterobacter spp without any labelling (Craig et al., 2013; Sengupta et al., 2012; Xie et al., 2013). Rapid measurement time, high resolution, sensitivity, and ease of operation make the SERS technology a promising diagnostic tool for foodborne pathogens (Wang et al., 2011; Gracie et al., 2014; Kearns et al., 2017;). The capability of SERS for identification and discrimination of bacterial species and strains rely on the bio recognition probes since the Raman peaks of 
all bacteria are very similar. The sensitivity of the SERS depends on the methodology of sample preparation, property of substrates and diagnostic nanoparticle used, and binding of bacteria on the SERS-active surface (Zhou et al., 2014; Yang et al., 2016). To date, there have been many reports on SERS biosensors for bacterial pathogen detection (Wang et al., 2011; Sundaram et al., 2013; Zhou et al., 2014; Granger et al., 2016). Taking advantages of the cutting-edge microfluidic techniques, the integration of SERS into microfluidics has also been conducted to fabricate portable biosensors for high speed and ultra-sensitive detection of different bacteria (Walter et al., 2011; L. Chen et al., 2015; Mungroo et al., 2016; C. Wang et al., 2017). For examples, Walter et al. (2011) successfully demonstrated a SERS based microfluidic platform for rapid and highly specific identification and classification of different $E$. coli strains using a microscopy with laser setup mounted on top of microfluidic channels. Researchers were able to detect bacteria by designing a system consisting of a microfluidic device and a micro-pump, which flushed the bacterial sample through the device to a Raman microscope where multiple bacterial strains were detected and analyzed using a $785 \mathrm{~nm}$ laser at concentrations of $10^{6} \mathrm{CFU} / \mathrm{ml}$ (Pazos-Perez et al., 2016). SERS based microfluidic platforms are reported in other studies for the detection of various foodborne pathogens (e.g., S. typhimirium, S. enteritis, Pseudomonas aeruginosa, L. monocytogenes, $L$. innocua, MRSA 35 and 86) (L. Chen et al., 2015; Mungroo et al., 2016).

Integration of nano-dielectrophoretic (nano-DEP) as a bacterial concentration approach (Cho et al., 2010; Khoshmanesh et al., 2012, 2011; Páez-Avilés et al., 2016) with ultrasensitive SERS detection has enabled Wang et al. (C. Wang et al., 2017) to demonstrate a portable lab-on-a-chip platform for the detection of E. coli O157:H7 with a LOD range of 1 to $10 \mathrm{CFU} / \mathrm{ml}$. The Nano-DEP microfluidic device consisted of a reservoir section with 
carbon nanofiber nanoelectrode array on the bottom and fluidic in and out channels (Figure 9A) to enrich the samples before mixing with SERS nanoprobes. The carbon nanofiber nanoelectrode in the Nano-DEP could generate a large DEP force $\left(F_{D E P}: 10^{20}\right.$ $\mathrm{V}^{2} \mathrm{~m}^{-3}$ ) when an alternating current voltage source was applied, resulting in the separation and concentration of the target cells by overcoming the hydrodynamic drag influence $\left(F_{D A G}\right)$. Next, the concentrated samples were detected by bioconjugated gold nanoparticles, nanorods or nanocages used as SERS enhancers.

\subsection{Electrochemical biosensors}

Electrochemical biosensors are applied in many fields of technology due to their low cost, user-friendly properties, ease of integration into microfluidic devices, compatibility with different fabrication methods, and well-established detecting performance. Conductometric/impedimetric, amperometric/voltammetric, and potentiometric methods are the most common electrochemical biosensing strategies that can be used and integrated into microfluidic devices. For example, Yang et al. (2008) miniaturized an impedance measurement into biochips and successfully increased the sensitivity of the impedance signals and reduced the time needed for the detection of foodborne bacteria. The attachment of bacteria cell on electrode surfaces can alter the interface impedance due to the insulating properties of the bacterial cell membrane, providing a simpler and cheaper detecting method than that of optical techniques (Ramaswamy et al., 2013). Besides, because of the quick response of the impedance biosensors, they can be used for real-time detection purposes. For example, Li et al. (2016) presented a microfluidic device with vertical electrodes for the impedance-based detection of foodborne pathogens. An easy to fabricate microfluidic impedance biosensor has been reported for rapid and 
accurate detection of $S$. typhimurium (Figure 9B). Monoclonal anti-Salmonella antibodies were immobilized on a high-density electrode array inside a microfluidic chip for selective detection using an impedance analyser. This microfluidic biosensor showed a 10-fold increase in sensitivity compared to a non-microfluidic biosensor (Ghosh Dastider et al., 2015). Online bacterial separation and detection is also achieved by integrating electrochemical impedance analysis and urease catalysis into a microfluidic device (Chen et al., 2016). For this purpose, Listeria monocytogenes cells, magnetic nanoparticles modified with the anti-Listeria monoclonal antibodies, and gold nanoparticles modified with anti-Listeria polyclonal antibodies and urease, were all mixed and incubated in a fluidic separation chip to form sandwich complexes of magnetic nanoparticle-Listeria-urease conjugated gold nanoparticles. After concentrating the complex by applying a high gradient magnetic field, urea was injected into the microfluidic system and hydrolysed into ammonium and carbonate ions due to the catalysis effect of the urease. These ions were then transported into a detection chamber integrated with interdigitated microelectrodes to detect the pathogen with a LOD of $1.6 \times 10^{2} \mathrm{CFU} / \mathrm{ml}$ in 1 hour. Voltammetric detection of Campylobacter spp. in raw poultry meat samples using thin-film gold electrodes deposited onto cyclo olefin polymer substrates is also reported. This LOC device was capable of detecting PCR amplicon of Campylobacter spp. with a LOD of 90 pM (Morant-Miñana and Elizalde, 2015). Tien et al. (2017) have also developed a microfluidic biochip for real-time electrochemical monitoring of viral pathogens based on nucleic acid amplification by loopmediated isothermal amplification (LAMP) technique. This platform offers an easy tool for quantification of foodborne pathogens with limited risk of cross-contamination. 


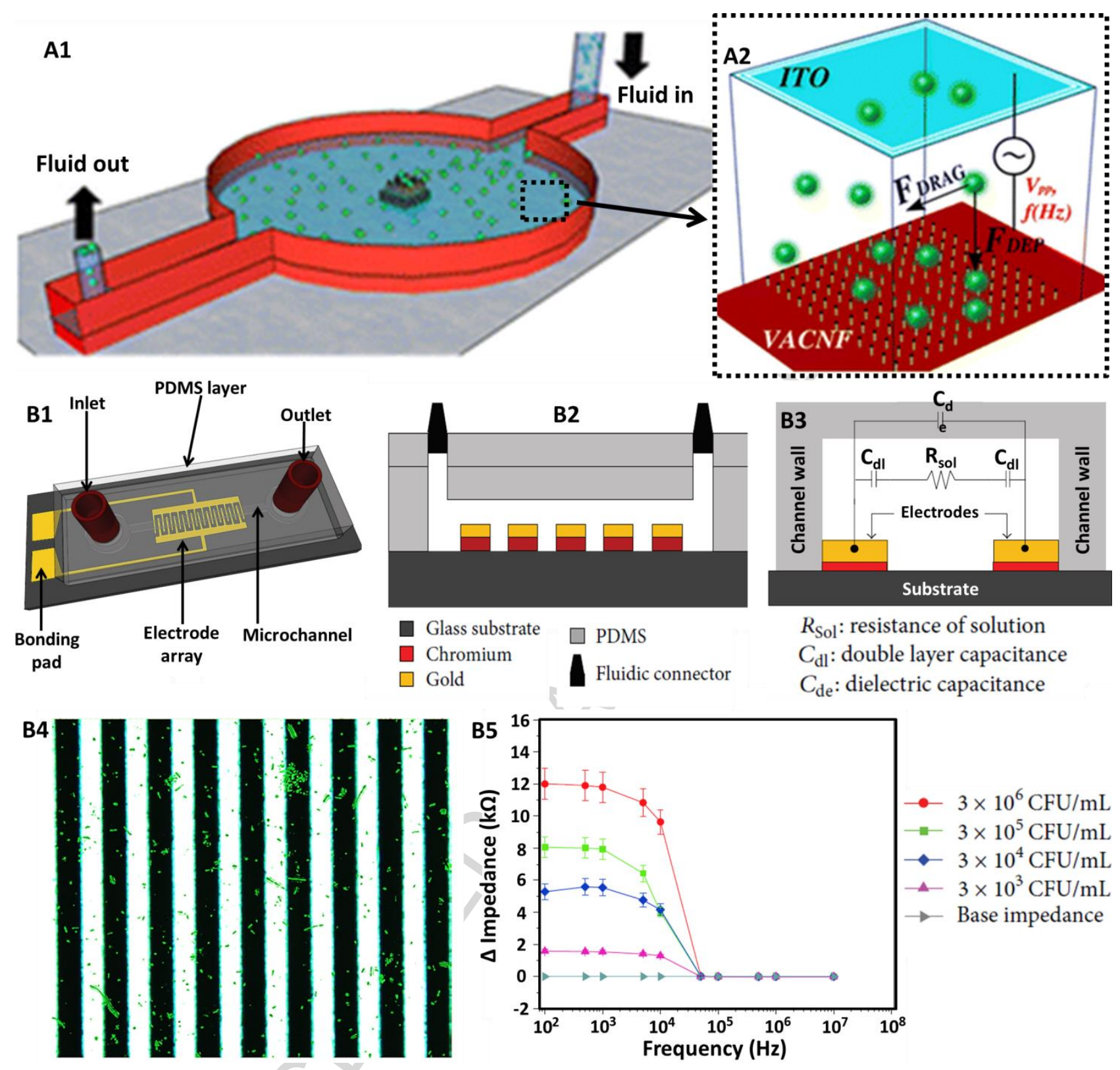

Figure 9. (A) Illustration of SERS based microfluidic system for pathogen detection. (A1) Schematic structure of nano-DEP microfluidic chip showing the design of microfluidic channel. (A2) Carbon-nanofiber nanoelectrode arrays at the central part of the device for sample concentration. Reprinted with permission from Ref. (Wang et al., 2017) copyright 2017 BioMedCentral Publisher. (B1) 3D schematic of the impedance biosensor showing the electrode array embedded under a microchannel with inlet and outlet. (B2) Crosssectional profile demonstrating various layers of the impedance biosensor. (B3) The equivalent circuit of the impedance biosensor demonstrating various circuit components. (B4) Optical image of immobilized bacteria on the array. (B5) Impedance response for different concentrations of $S$. typhimurium. Reprinted with permission from Ref. (Ghosh Dastider et al., 2015) copyright 2015 Hindawi Publisher. 
Nanomaterials are widely used in electrochemical biosensing devices. Gold nanoparticles, iron oxide magnetic nanoparticles, and carbon-based nanomaterials have provided promising opportunities to explore nanoscale electrochemical biosensors due to their biocompatibility and high surface areas that can enhance bio-receptor loading and stability. These conductive materials can serve as efficient agents for electron transfer between the bio-receptors and the electrode surface, allowing electrochemical sensing of foodborne pathogens without necessity of using electron transfer mediators (Wang, 2005; Hernandez and Ozalp, 2012; Wang and Dai, 2015; Zeng et al., 2016; Chen et al., 2016). Ma et al. (2014) proposed an impedimetric biosensor using graphene oxide and gold nanoparticle modified glassy carbon electrodes as transducers for Salmonella spp. detection. Graphene oxide particles were first dispersed and dried on the electrode, followed by electrodeposition of gold nanoparticles and surface functionalization with Salmonella-specific aptamer. A LOD of $3 \mathrm{CFU} / \mathrm{ml}$ was achieved and recoveries were close to $100 \%$ for the 10 to $1000 \mathrm{CFU} / \mathrm{ml}$ of bacteria spiked in pork samples. Multiplexed detection of pathogens is also reported by electrochemical biosensing platforms. Dou et al., (2013) reported an interesting work where E. coli O157:H7 and Enterobacter sakazakii (E. sakazakii) were detected using carbon screen-printed low-density arrays coated with multi-walled carbon nanotubes/sodium alginate/carboxymethyl chitosan composite films that were further functionalized with horseradish peroxidase labeled antibodies. The LODs were $3.47 \times 10^{3}$ and $4.57 \times 10^{3} \mathrm{CFU} / \mathrm{ml}$ for E. coli $\mathrm{O} 157: \mathrm{H} 7$ and E. sakazakii, respectively. Table 3 has summarized examples of nanomaterial used for foodborne pathogen detection. 
Table 3. Examples of nanomaterials used for electrochemical biosensing of foodborne pathogens.

\begin{tabular}{|l|l|l|l|l|l|}
\hline Bacteria & Nanomaterial & Bioreceptor & Sample & LOD & Reference \\
\hline $\begin{array}{l}\text { Brucella } \\
\text { melitensis }\end{array}$ & Gold nanoparticle & Antibodies & Spiked milk & $\begin{array}{l}4 \times 10^{5} \\
\text { CFU/ml }\end{array}$ & $\begin{array}{l}\text { (Wu et al., } \\
\text { 2013) }\end{array}$ \\
\hline $\begin{array}{l}\text { Campylobacter } \\
\text { jejuni }\end{array}$ & $\begin{array}{l}\text { Carboxylated carbon } \\
\text { nanotubes }\end{array}$ & Antibodies & $\begin{array}{l}\text { Spiked bovine } \\
\text { milk }\end{array}$ & $400 \mathrm{CFU} / \mathrm{ml}$ & $\begin{array}{l}\text { (Viswanathan } \\
\text { et al., 2012) }\end{array}$ \\
\hline Bacillus cereus & Gold nanoparticles & Antibodies & Spiked milk & $10 \mathrm{CFU} / \mathrm{ml}$ & $\begin{array}{l}\text { (Kang et al., } \\
\text { 2013) }\end{array}$ \\
\hline $\begin{array}{l}\text { Listeria } \\
\text { monocytogenes }\end{array}$ & $\begin{array}{l}\text { Iron oxide } \\
\text { nanoparticles }\end{array}$ & Antibodies & $\begin{array}{l}\text { Milk, lettuce, } \\
\text { and ground beef }\end{array}$ & $10^{3} \mathrm{CFU/ml}$ & $\begin{array}{l}\text { (KANAYVA } \\
\text { et al., 2012) }\end{array}$ \\
\hline E. coli O157:H7 & $\begin{array}{l}\text { Carboxylated carbon } \\
\text { nanotubes }\end{array}$ & Antibodies & $\begin{array}{l}\text { Spiked bovine } \\
\text { milk }\end{array}$ & $800 \mathrm{CFU/ml}$ & $\begin{array}{l}\text { (Viswanathan } \\
\text { et al., 2012) }\end{array}$ \\
\hline S. aureus & $\begin{array}{l}\text { Graphene oxide and } \\
\text { gold nanoparticles }\end{array}$ & Aptamers & Fish, water & $10 \mathrm{CFU} / \mathrm{ml}$ & $\begin{array}{l}\text { (Jia et al., } \\
2014)\end{array}$ \\
\hline Salmonella spp. & $\begin{array}{l}\text { Graphene oxide and } \\
\text { gold nanoparticles }\end{array}$ & Aptamers & $\begin{array}{l}\text { Spiked pork } \\
\text { meat }\end{array}$ & $3 \mathrm{CFU/ml}$ & $\begin{array}{l}\text { (Ma et al., } \\
\text { 2014) }\end{array}$ \\
\hline
\end{tabular}

\subsection{Microfluidics based immunological detection methods}

POC testing is a rapidly growing diagnosis strategy in food safety as it provides results faster than conventional methods. Lateral flow assays (LFAs) based POC devices are one of the most common approaches for rapid online detection of foodborne pathogens. LFA provides a visual response based on the immunochromatographic concept. This technology is based on capillary forces for fluid transport where the test sample flows along a series of capillary beds (e.g., porous paper, microstructured polymer, or sintered polymer), and encounters and binds to labelled diagnostic markers (colouring agent) on its way, and then reaches to a detection zone where capturing molecules are localized on the capillary bed. When more fluid passes through the detection zone, more colouring agent accumulates, and colour change can be observed (Cho et al., 2015). The LFA technology renders many advantages to foodborne pathogen detection, including rapid one step analysis, low operational cost, simple instrumentation, user-friendly format, high specificity and sensitivity, less interferences due to chromatographic separation, and portability (Sajid 
et al., 2015; Shan et al., 2015). Moreover, the capillary force principle applied in LFA devices allows the performance of the assay without any external power, and the white background of the paper (or other capillary bed materials) allows naked-eye observation of the colour change in the detection zone. The LFA technology has been combined with various techniques, such as paper chromatography, chemical colorimetric assay, enzyme inhibition technology, immune-sandwich assay, biochemical and biomolecular reactions to facile pathogen detection in food samples (Cheng et al., 2014). Different types of labels, including gold, silver, and selenium nanoparticles, quantum dots, up-converting phosphors, fluorescent and luminescent materials, etc., are utilized as visualizing markers for LFAs to improve the sensitivity of detection (Quesada-González and Merkoçi, 2015; Tripathi et al., 2017). In a study performed by Wang et al. (W. Wang et al., 2017), the test line of the nitrocellulose membrane was functionalized with monoclonal antibodies against P60 protein of Listeria, and L. monocytogenes monoclonal antibodies labelled with gold nanoparticles were used to specifically detect the pathogen using antibody-based sandwich concept. This LFA was applied to detect L. monocytogenes in spiked milk samples with a detection limit of $3.7 \times 10^{6} \mathrm{CFU} / \mathrm{ml}$ within 13 hours. Table 4 shows a list of recent studies using LFA to detect foodborne pathogens in food samples.

Enzyme-linked immunosorbent assay (ELISA) is another immunological technology, which can be employed in LOC systems for rapid online detection of foodborne pathogens (Wang and Salazar, 2016; Yoon and Kim, 2012). This technology can be integrated into microchannels of LOC systems instead of the conventional micro-well plates (Seo et al., 2010). In this method, the target solution will flow continuously in the microchannels and antibodies immobilized on the surface of the microchannel can subsequently capture pathogens. Then, a labelled secondary antibody can be used for the detection of the 
pathogens using a sensor placed on top of the location where the primary pathogen capturing antibodies are immobilized. The key benefit of this method is very effective rinsing of residues in the channels by continuous flow, as well as rapidity and simplicity of the procedures. However, using ELISA methods in microfluidic devices usually suffer from minimal signal amplification, necessity of time-consuming procedures for the immobilization of capturing antibodies on the device, non-specific bindings, high cost of antibodies, possible occurrence of cross-reactivity that might result in nonspecific signals, and strict considerations for storage condition to maintain the activity of antibodies (Lequin, 2005; Baid, 2016).

Table 4. Various examples of lateral flow based microfluidic technologies used for the detection of foodborne pathogens.

\begin{tabular}{|c|c|c|c|c|c|}
\hline $\begin{array}{l}\text { Detection technologies } \\
\text { for lateral flow test } \\
\text { assay (DNA/Protein } \\
\text { targets) }\end{array}$ & Label & $\begin{array}{l}\text { Foodborne } \\
\text { pathogen }\end{array}$ & $\begin{array}{l}\text { Sample } \\
\text { matrix }\end{array}$ & $\begin{array}{l}\text { Assay } \\
\text { sensitivity }\end{array}$ & $\begin{array}{l}\text { Referenc } \\
\text { e }\end{array}$ \\
\hline \multirow{2}{*}{$\begin{array}{l}\text { DNA targets } \\
\text { PCR based nucleic acid } \\
\text { amplification }\end{array}$} & \multirow{2}{*}{$\begin{array}{l}\text { Gold } \\
\text { nanoparticle } \\
\text { s }\end{array}$} & E. coli $\mathrm{O} 157: \mathrm{H} 7$ & \multirow{2}{*}{$\begin{array}{l}\text { Purified } \\
\text { DNA } \\
\text { solution }\end{array}$} & $\begin{array}{l}7 \mathrm{pg} / \mu \mathrm{l} \mathrm{PCR} \\
\text { Amplicon }\end{array}$ & \multirow{2}{*}{$\begin{array}{l}\text { (Ben } \\
\text { Aissa et } \\
\text { al., 2017) }\end{array}$} \\
\hline & & $\begin{array}{l}\text { Salmonella } \\
\text { enterica }\end{array}$ & & $\begin{array}{l}95 \mathrm{pg} / \mathrm{ul} \\
\text { PCR } \\
\text { Amplicon }\end{array}$ & \\
\hline $\begin{array}{l}\text { DNA targets } \\
\text { Multiple cross } \\
\text { displacement amplification }\end{array}$ & $\begin{array}{l}\text { Gold } \\
\text { nanoparticle } \\
s\end{array}$ & $\begin{array}{l}\text { Listeria } \\
\text { monocytogenes }\end{array}$ & $\begin{array}{l}\text { Extracted } \\
\text { DNA from } \\
\text { spiked } \\
\text { pork } \\
\text { sample }\end{array}$ & $\begin{array}{l}10 \mathrm{fg} \\
\text { DNA/reactio } \\
\mathrm{n}\end{array}$ & $\begin{array}{l}\text { (Li et al., } \\
2017)\end{array}$ \\
\hline $\begin{array}{l}\text { Protein targets } \\
\text { Signal } \\
\text { amplification immunoassa } \\
\text { y }\end{array}$ & $\begin{array}{l}\text { FITC } \\
\text { labelled } \\
\text { antigen and } \\
\text { antibody }\end{array}$ & E. coli O157:H7 & $\begin{array}{l}\text { Bread } \\
\text { Milk } \\
\text { Jelly }\end{array}$ & $1 \mathrm{CFU} / \mathrm{ml}$ & $\begin{array}{l}\text { (Song et } \\
\text { al., 2016) }\end{array}$ \\
\hline $\begin{array}{l}\text { Protein targets } \\
\text { Immuno-magnetic } \\
\text { separation }\end{array}$ & $\begin{array}{l}\text { Fluorescent } \\
\text { nanobeads }\end{array}$ & E. coli O157:H7 & Milk & $1 \mathrm{CFU}$ & $\begin{array}{l}\text { (Huang et } \\
\text { al., 2016) }\end{array}$ \\
\hline $\begin{array}{l}\text { DNA targets } \\
\text { Multiplex loop-mediated } \\
\text { isothermal amplification }\end{array}$ & $\begin{array}{l}\text { Gold } \\
\text { nanoparticle } \\
\text { s }\end{array}$ & $\begin{array}{l}\text { Staphylococcal } \\
\text { enterotoxins }\end{array}$ & $\begin{array}{l}\text { Milk } \\
\text { Apple } \\
\text { juice } \\
\text { Cheese } \\
\text { Rice }\end{array}$ & $1 \mathrm{CFU} / \mathrm{ml}$ & $\begin{array}{l}\text { (H. Y. Yin } \\
\text { et al., } \\
\text { 2016) }\end{array}$ \\
\hline $\begin{array}{l}\text { Protein targets } \\
\text { Immunoassay }\end{array}$ & $\begin{array}{l}\text { Luminescent } \\
\text { reporter (Up- }\end{array}$ & $\begin{array}{l}\text { E. coli } \\
\text { O157:H17, }\end{array}$ & $\begin{array}{l}\text { Dairy } \\
\text { products }\end{array}$ & $\begin{array}{l}10 \\
\text { CFU/0.6 mg }\end{array}$ & $\begin{array}{l}\text { (Zhao et } \\
\text { al., 2016) }\end{array}$ \\
\hline
\end{tabular}




\begin{tabular}{|l|l|l|l|l|l|}
\hline & $\begin{array}{l}\text { converting } \\
\text { Phosphor } \\
\text { Technology) }\end{array}$ & $\begin{array}{l}\text { S. enteritidis, } \\
\text { S. choleraesuis, } \\
\text { V. cholera O139, } \\
\text { V. } \\
\text { parahaemolyticu } \\
\text { s }\end{array}$ & $\begin{array}{l}\text { Marine } \\
\text { products } \\
\text { Beverage } \\
\text { s } \\
\text { Snacks } \\
\text { Meats }\end{array}$ & & \\
\hline $\begin{array}{l}\text { DNA targets } \\
\text { Aptamer-based isothermal } \\
\text { strand displacement } \\
\text { amplification (SDA) }\end{array}$ & $\begin{array}{l}\text { Colorimetric } \\
\text { beads }\end{array}$ & E. coli O157:H7 & PBS & $\begin{array}{l}\text { 10 CFU per } \\
\text { test }\end{array}$ & (Wu et al., \\
2015)
\end{tabular}

\subsection{Nucleic acid-based methods for on-chip pathogen detection}

The integration of nucleic acid-based detection technologies in microfluidic devices have attracted attention from researchers due to the low sample volume, rapidity of assay time and facile sample handling process. Nucleic acid-based detection methods play an important role in improved sensitivity and specificity of pathogen sensing in food samples (Gomez-Zavaglia et al., 2016; Mangal et al., 2017). Nucleic acid (NA) amplification technologies can be an efficient substitute for the time-consuming culture based detection methods, particularly when the target concentration is very low. A number of NA-based methods, such as polymerase chain reaction (PCR), loop-mediated isothermal amplification (LAMP), recombinase polymerase amplification (RPA), nucleic acid sequence-based amplification (NASBA), and helicase dependent amplification (HDA), recently used for POC diagnostic of foodborne pathogens, are described in this section. 


\subsubsection{Polymerase chain reaction (PCR)}

PCR is one of the most widely used techniques in molecular biology for DNA amplification. Integration of PCR into microfluidic devices, which are capable to provide higher surface to volume ratio, faster rate of mass and heat transfer and the ability to precisely handle very small volume of reagents, can result in miniaturized, portable and rapid detection platforms with favourable performance. Tachibana et al. (Tachibana et al., 2015) fabricated a self-propelled continuous-flow PCR (SP-CF-PCR) chip for rapid and quantitative detection of $E$. coli $\mathrm{O} 157$ with a detection sensitivity of $0.031 \mathrm{pg} / \mu \mathrm{l}$ of purified DNA. Injection-moulded cyclo-olefin polymer (COP) was used as a cost-effective method to fabricate the disposable microfluidic PCR chip. In this system, the PCR chip was placed on two heater blocks with adjusted temperatures of $95^{\circ} \mathrm{C}$ and $60{ }^{\circ} \mathrm{C}$ (Figure 10A). The PCR solution loaded into the inlet flows into the microchannels by capillary force. A driving microchannel placed behind the PCR microchannel maintains the capillary force to control the flow of the solution. DNA amplification was performed within the chip and fluorescence signals were screened as the detection marker. In another study, Shu et al. (2014) reported a segmented continuous-flow multiplex polymerase chain reaction (SCF-MPCR) on a spiral-channel microfluidic device consisting of disposable polytetrafluoroethylene (PTFE) capillary microchannel coiled on three isothermal blocks for multiple identification of DNAs of S. enterica, L. monocytogenes, E. coli O157:H7 and S. aureus. The segmented flow regimes were sequentially generated in a microchannel, while the channel was coiled around three heating zones with constant predefined temperatures for denaturation, annealing, and extension (Figure 10B). The multiplex PCR mixture of each sample segment was containing multiple pairs of primers together with different (multiple) 
DNA templates. The system was a proof of concept for the multiplex detection of bacterial pathogens using purified DNA isolated from spiked banana, milk, and sausage, with a detection limit of 100 copies/ $\mu \mathrm{l}$.

In addition to PCR integrated microfluidic devices, Bian et al. (2015) described a droplet digital PCR (ddPCR) platform for the simultaneous and sensitive detection of pathogenic bacteria in water. In this ddPCR platform, a mineral oil-saturated polydimethylsiloxane (OSP) chip was used to overcome the problem of water droplet evaporation. The system integrated droplet generation, on-chip amplification and end-point fluorescence readout (Figure 10C) to detect E. coli O157:H7 and L. monocytogenes with a detection limit of 10 CFU/ml in drinking water. Hung et al. (2016) reported a novel LOC platform with integrated injection-moulded polymeric supercritical angle fluorescence (SAF) micro-lens array for rapid multiplexed solid phase amplification and detection of various Salmonella species. (Figure 10D). In this system, pathogen-specific DNA probes were immobilized directly on the surface of the SAF array located at the bottom of a microchamber. The PCR reaction mixture was mixed with small amount of forward and Cy3-labeled reverse primers in solution. After the initial amplification of the pathogen DNA in the liquid phase to increase the copy number of DNA templates, the targeted DNA will bind to the immobilized probes on the SAF array, and the polymerase will extend the matched probes. Using this method, highly-multiplexed amplification can be achieved in a small space with thousands of different probes located at separate spots. After the reaction, PCR products could remain attached on the surface through covalent binding, and fluorescence signals were collected through the SAF structures, allowing their detection using a CCD sensor. 


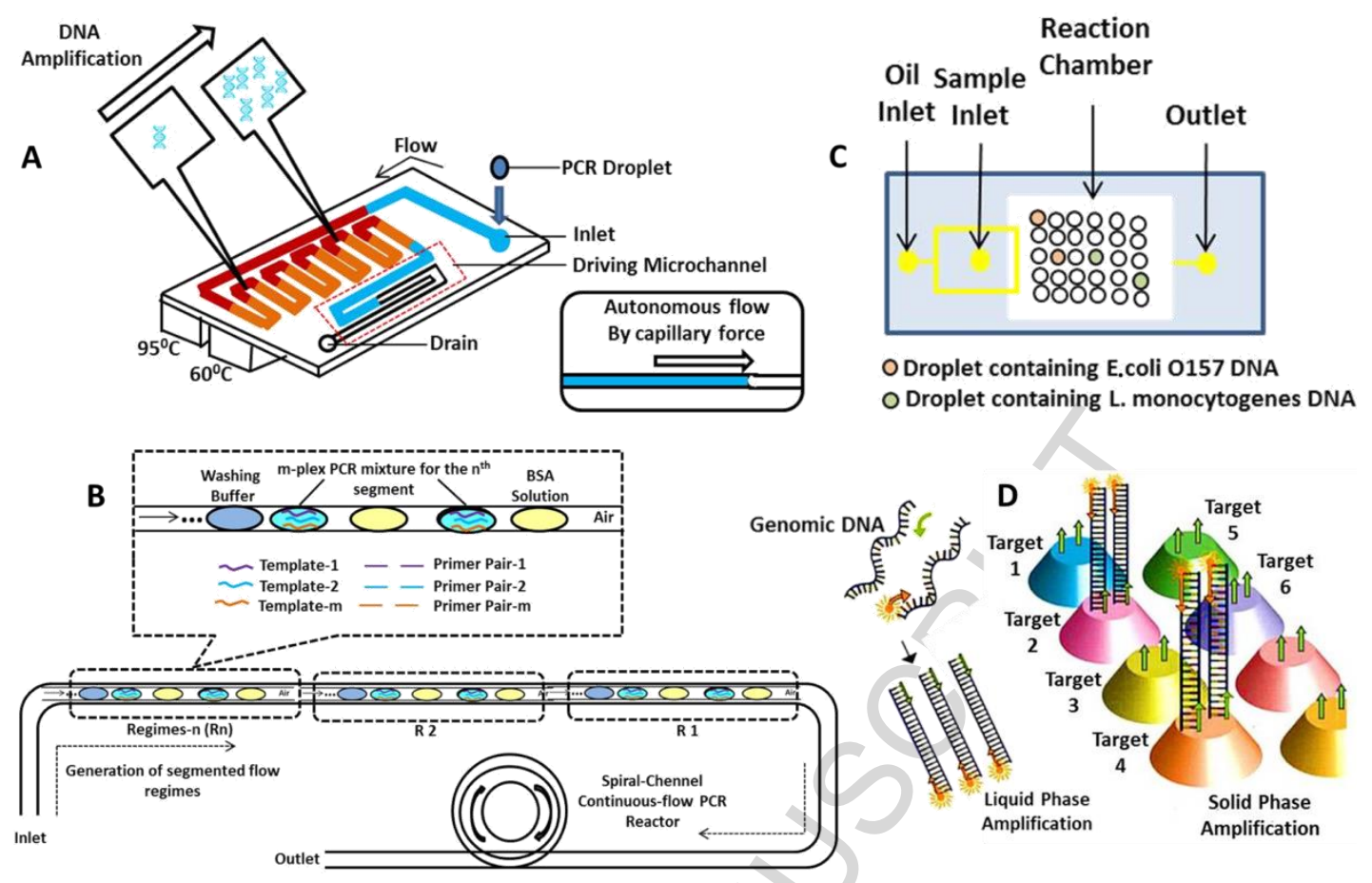

Figure 10. Different PCR based DNA amplification strategies on microfluidic devices for pathogen detection. (A) Self-propelled continuous-flow PCR (SP-CF-PCR) chip. The PCR solution is loaded into the inlet hole, where it will autonomously flow by capillary force. The driving microchannel shown in the illustration will maintain the capillary force for continuous flow of the solution. Adapted with permission from ref. (Tachibana et al., 2015), 2015 copyright Elsevier B.V. (B) Design principle of the spiral-channel SCF-MPCR platform for on-chip amplification. Adapted with permission from ref. (Shu et al., 2014), 2014 copyright Elsevier B.V. (C) Fabricated mineral oil saturated PDMS (OSP) microfluidic chip for simultaneous detection of $E$. coli 0157 and L. monocytogenes by DD-PCR. Samples dropped into the inlet were drawn to the cross-section using a syringe pump applied at the outlet, resulting in the formation of nano-droplets. Reproduced with permission from (Bian et al., 2015), 2015 copyright Elsevier B.V. (D) Concept of SP-PCR performance on SAF array design. Adapted with permission from ref. (Hung et al., 2016), 2016 copyright Elsevier B.V.

\subsubsection{Loop mediated isothermal amplification (LAMP)}

Isothermal DNA amplification technologies serve as desirable alternative to PCR methods due to their performance at a constant temperature and less energy required. PCR methods are limited by the thermal constrains and needs an electrically powered thermal cycler with precise control of the three temperature stages and a fast transition between stages, which is usually accomplished by a bulky and power-intensive apparatus. 
Integration of isothermal DNA amplification technologies in microfluidic detection system can make it easier to develop portable microfluidic platforms for the POC assays. Table 5 shows several examples of different isothermal DNA amplification technologies used for foodborne pathogen detection.

In LAMP, the target sequence is amplified at a constant temperature of $60-65^{\circ} \mathrm{C}$ using either two or three sets of primers and a polymerase with high strand displacement activity and replication activity (Nagamine et al., 2002; Notomi, 2000). This technique produces a tremendous amount of amplified products that may even be detected by naked eyes when using appropriate DNA staining techniques (Amin Almasi, 2012; Xie et al., 2014). LAMP has been widely used for identification of various foodborne pathogens, such as Salmonella spp., Campylobacter spp., Listeria spp., E. coli, S. aureus, Clostridium, etc. (Mori et al., 2013; Niessen et al., 2013). Oh et al. (2016) developed a miniaturized colorimetric centrifugal device coupled with LAMP for the identification of multiple foodborne pathogens, including S. typhimurium, E. coli $\mathrm{O} 157$ and Vibrio parahaemolyticus. Similarly, a microfluidic platform with 16 amplification chambers for LAMP reaction coupled with colorimetric assay was developed. In this system, all the main steps, such as pathogen detection, reagent preparation, LAMP, and detection are integrated into a single microfluidic compact disc (Sayad et al., 2016). Different studies have adopted LAMP to LOC systems using real-time fluorescence detection for quantitative analysis of multiple foodborne pathogens (Tourlousse et al., 2012; Duarte et al., 2013). However, in all these systems, the sample preparation and nucleic acid purification processes were performed off-chip prior to LAMP amplification. Sun et al (2015) reported a real time quantitative detection method using an eight-chamber LOC system integrated with magnetic beadbased sample preparation and LAMP for rapid real-time detection of Salmonella in 
enriched pork meat samples. Simple design, together with the high capacity of integration, facile isothermal amplification, and quantitative analysis of multiple samples in short time has been shown as the practical applicability of all the LAMP mediated LOC systems for rapid on-site screening of various food borne pathogens. 
Table 5. Examples of different isothermal DNA amplification technologies performed for microfluidic based identification of various foodborne pathogens.

\begin{tabular}{|c|c|c|c|c|c|}
\hline $\begin{array}{c}\text { DNA } \\
\text { amplification } \\
\text { technology }\end{array}$ & $\begin{array}{l}\text { Technology and } \\
\text { detection } \\
\text { system }\end{array}$ & Foodborne Pathogen & $\begin{array}{l}\text { Sample } \\
\text { matrix }\end{array}$ & $\begin{array}{l}\text { Assay } \\
\text { sensitivity }\end{array}$ & Reference \\
\hline \multirow{5}{*}{ LAMP } & \multirow{2}{*}{$\begin{array}{l}\text { centrifugal } \\
\text { microfluidic } \\
\text { device }\end{array}$} & $\begin{array}{l}\text { S. typhimurium, E. coli } \\
\text { O157:H7, Vibrio } \\
\text { parahaemolyticus }\end{array}$ & $\begin{array}{l}\text { Purified } \\
\text { DNA }\end{array}$ & $\begin{array}{l}0.2 \mathrm{pg}(380 \\
\text { copies) }\end{array}$ & $\begin{array}{l}\text { (Oh et al., } \\
2016)\end{array}$ \\
\hline & & Salmonella & $\begin{array}{l}\text { Purified } \\
\text { DNA from } \\
\text { spiked } \\
\text { Tomatos } \\
\end{array}$ & $5 \mathrm{pg} / \mathrm{ul}$ & $\begin{array}{l}\text { (Sayad et } \\
\text { al., 2016) }\end{array}$ \\
\hline & \multirow{3}{*}{$\begin{array}{l}\text { Real time LAMP } \\
\text { on polymeric } \\
\text { chip }\end{array}$} & $\begin{array}{l}\text { Salmonella, Campylobacter } \\
\text { jejuni, Shigella } \\
\text { Vibrio cholerae }\end{array}$ & $\begin{array}{l}\text { Purified } \\
\text { DNA }\end{array}$ & $\begin{array}{l}10-100 \\
\text { Genome/ul }\end{array}$ & $\begin{array}{l}\text { (Tourlousse } \\
\text { et al., } \\
2012 \text { ) }\end{array}$ \\
\hline & & $\begin{array}{l}\text { Listeria monocytogenes, E. } \\
\text { coli } \\
\text { Salmonella }\end{array}$ & $\begin{array}{l}\text { Cultured } \\
\text { cell }\end{array}$ & $10^{5} \mathrm{CFU} / \mathrm{ml}$ & $\begin{array}{l}\text { (Duarte et } \\
\text { al., 2013) }\end{array}$ \\
\hline & & Salmonella & Spiked pork & $\begin{array}{l}50 \\
\text { cells/reaction }\end{array}$ & $\begin{array}{l}\text { (Sun et al., } \\
2015)\end{array}$ \\
\hline \multirow{3}{*}{ RPA } & \multirow{2}{*}{$\begin{array}{l}\text { centrifugal } \\
\text { microfluidic } \\
\text { device }\end{array}$} & Salmonella & $\begin{array}{l}\text { PBS } \\
\text { Milk }\end{array}$ & $\begin{array}{l}10 \mathrm{CFU} / \mathrm{ml} \\
10^{2} \mathrm{CFU} / \mathrm{ml}\end{array}$ & $\begin{array}{l}\text { (Choi et al., } \\
2014)\end{array}$ \\
\hline & & $\begin{array}{l}\text { S. enterica, E. coli } \\
\text { O157:H7, Vibrio } \\
\text { parahaemolyticus }\end{array}$ & Milk & 4 cells/3.2 ul & $\begin{array}{l}\text { (Oh et al., } \\
2016)\end{array}$ \\
\hline & $\begin{array}{l}\text { centrifugal } \\
\text { microfluidic } \\
\text { device }\end{array}$ & $\begin{array}{l}\text { Enterococcus faecium, S. } \\
\text { aureus, Escherichia coli } \\
\text { MG 1655, Pseudomonas } \\
\text { aeruginosa }\end{array}$ & $\begin{array}{l}\text { PBS, } \\
\text { Milk }\end{array}$ & $\begin{array}{l}10 \mathrm{CFU} / \mathrm{ml} \\
10^{2} \mathrm{CFU} / \mathrm{ml}\end{array}$ & $\begin{array}{l}\text { (Kim et al., } \\
2014)\end{array}$ \\
\hline \multirow{2}{*}{ NASBA } & $\begin{array}{l}\text { immobilized tm } \\
\text { RNA extraction }\end{array}$ & S. pneumoniae & $\begin{array}{l}\text { Cultured } \\
\text { sample }\end{array}$ & $0.1-10 \mathrm{CFU}$ & $\begin{array}{l}\text { (Scheler et } \\
\text { al., 2011) }\end{array}$ \\
\hline & $\begin{array}{l}\text { Immunocapturing } \\
\text { coupled with } \\
\text { NASBA }\end{array}$ & E. coli, Rotavirus & Water & $10^{5} \mathrm{CFU} / \mathrm{ml}$ & $\begin{array}{l}\text { (Zhao et } \\
\text { al., 2012) }\end{array}$ \\
\hline
\end{tabular}

\subsubsection{Recombinase polymerase amplification (RPA)}

The RPA amplifies DNA at a constant temperature between $37^{\circ} \mathrm{C}$ to $42^{\circ} \mathrm{C}$ using target specific primer pair in combination with three core enzymes, i.e., recombinase, single stranded DNA binding protein and a strand displacing polymerase. The RPA reaction progresses rapidly and results in specific DNA amplification from just a few target copies to 
detectable levels, within $10 \mathrm{~min}$. In RPA, the use of probes containing a nucleotide analogue along with exonuclease III enzyme allows real-time fluorescent detection while endonuclease IV enzyme facilitates the detection of amplified RPA products in lateral flow based strip (Piepenburg et al., 2006). Recently, various RPA based assays have been developed for the detection of Salmonella (Santiago-Felipe et al., 2015), Listeria (Eid and Santiago, 2017), Norovirus (Moore and Jaykus, 2016) and Shiga toxin-producing Escherichia (Murinda et al., 2014). Kim et al. (2014) reported a fully integrated Lab on a disk system where three steps, including DNA extraction, RPA amplification, and detection, were integrated into a single disc. A single laser diode was utilized for wireless control of valve actuation, cell lysis, and noncontact heating in the isothermal amplification step. Similarly, Renner et al (2017) described a micro-device for the multiplex detection of various food poisoning bacteria. This microdevice was composed of identical triplicate functional units, where each unit has four reaction chambers, thereby making it possible to perform twelve direct RPA reactions simultaneously. In addition, vacuum degassed microfluidic cartridge, preloaded with lyophilized RPA reagents, were used for high sensitive (LOD of $\sim 10$ nucleic acid molecules) detection of various bacterial pathogens (Enterococcus faecium, Pseudomonas aeruginosa, S. aureus, Klebsiella pneumoniae, Acinetobacter baumannii, and Enterobacter spp.). This device uses a small portable battery-powered electronic reader to endow the device with the advantage of low power consumption and cost.

\subsubsection{Nucleic acid sequence based amplification (NASBA)}

NASBA is an alternative method to RT-PCR for the amplification of RNA at a constant temperature around $41^{\circ} \mathrm{C}$. A NASBA reaction consists of avian myeloblastosis virus (AMV) reverse transcriptase $(\mathrm{RT})$, T7 RNA polymerase, RNase $\mathrm{H}$ and two oligonucleotide 
primers. The NASBA reaction does not generate false positive amplification caused by genomic dsDNA, as is the case for RT-PCR (Compton, 1991). The amplification product of the NASBA is a single stranded RNA, which can be further detected by various techniques such as electrophoresis, hybridization probes, and lateral flow assays. A number of realtime NASBA are already in use for detection of various foodborne pathogens, including $S$. enterica, Vibrio cholerae, S. aureus, Campylobacter jejuni, and Campylobacter coli (Simpkins et al., 2000; Churruca et al., 2007; Fykse et al., 2007; O'Grady et al., 2009;). Dominov et al. (2008) developed NASBA based microfluidic devices incorporating all the steps of transfer-messenger RNA (tRNA) purification, NASBA-based amplification, and real-time fluorescence detection in a single, monolithic, PDMS microfluidic device. They applied silica bead immobilization on the substrate surface for capturing tRNA, which increased the effectiveness of sample purification and sample concentration.

It is worth pointing out that NASBA-mediated microdevices are not only applied for identification of microbes, but also for other purposes such as RNA purification, amplification, and detection in different point-of-care molecular diagnostics. For example, Zhao et al. (2012) reported a real time immuno-NASBA assay integrated into a PMMA LOC device for quantitative detection of waterborne pathogens like E. coli and Rotavirus with a LOD of $10^{5} \mathrm{CFU} / \mathrm{mL}$.

\subsubsection{Helicase dependent amplification (HDA)}

In HDA technology, DNA helicase is applied to generate single-stranded templates, which are then available for primer hybridization and subsequent primer extension by a DNA polymerase (Vincent et al., 2004). HDA occurs at a fixed temperature and utilizes a simple and rapid reaction mechanism for exponential amplification of the target sequence. These properties show great potential in simplifying portable POC devices for online food 
analysis. Over the last years, HDA has been implemented in various microfluidic devices. In some of these systems, all the steps, including DNA extraction, amplification, and detection have been integrated into a single device while some required separate DNA extraction steps (Mahalanabis et al., 2010; Huang et al., 2013). Zhang et al. (2011) developed a total integrated droplet-based microfluidic system using HDA for detection of E. coli. Andresen et al. (2009) also described the combination of HDA with microarraybased detection of $N$. gonorrhoeae and $S$. aureus pathogens. The simplicity of the reaction setup, potential for multiplexed analysis and possibility of miniaturization are the main advantages of this system, owning a possibility to be adapted for the integration into LOC devices and rapid online detection of foodborne pathogens. However, development of such systems is still at its infancy stage and needs further research to develop miniaturized devices for foodborne pathogen detection. As a summary, Table 6 has listed the main advantages and limitations of various detection techniques applied for microfluidic based foodborne pathogen detection.

Table 6. The summary of advantages and disadvantages of detection methods applied on microfluidic devices.

\begin{tabular}{|c|c|c|c|c|}
\hline \multicolumn{2}{|c|}{ Detection mode } & Advantages & Disadvantages & Reference \\
\hline \multirow[b]{2}{*}{$\begin{array}{l}\text { Biosensor- } \\
\text { based }\end{array}$} & $\begin{array}{c}\text { Optical } \\
\text { Biosensors }\end{array}$ & $\begin{array}{l}\text { - Desirable sensitivity } \\
\text { - Allows real-time } \\
\text { detection } \\
\text { - Enables label-free } \\
\text { detection }\end{array}$ & $\begin{array}{l}\text { - High cost } \\
\text { - Poor specificity } \\
\text { - Interference with food }\end{array}$ & $\begin{array}{l}\text { (Choi et al., } \\
\text { 2016; Yoo and } \\
\text { Lee, 2016) }\end{array}$ \\
\hline & $\begin{array}{l}\text { Electrochemical } \\
\text { Biosensors }\end{array}$ & $\begin{array}{l}\text { - Automated } \\
\text { - Handling large } \\
\text { numbers of samples } \\
\text { - Enables label-free } \\
\text { detection }\end{array}$ & $\begin{array}{l}\text { - Poor specificity } \\
\text { - Difficult to test samples } \\
\text { with low amount of } \\
\text { microorganisms } \\
\text { - High risk of Interference } \\
\text { with food matrices } \\
\text { - Many washing steps }\end{array}$ & $\begin{array}{l}\text { (Ronkainen et } \\
\text { al., 2010; Vidal } \\
\text { et al., 2013) }\end{array}$ \\
\hline $\begin{array}{l}\text { Immunological } \\
\text { methods }\end{array}$ & ELISA & $\begin{array}{l}\text { - Desirable Specificity } \\
\text { - Possibility of } \\
\text { detecting bacterial } \\
\text { toxins } \\
\text { - Handling large }\end{array}$ & $\begin{array}{l}\text { - Risk of cross-reactivity } \\
\text { with similar antigens } \\
\text { - Low sensitivity } \\
\text { - False negative results } \\
\text { - Requires trained personnel }\end{array}$ & $\begin{array}{l}\text { (Law et al., } \\
\text { 2014; Ng et al., } \\
\text { 2010; Thiha } \\
\text { and Ibrahim, } \\
\text { 2015) }\end{array}$ \\
\hline
\end{tabular}




\begin{tabular}{|c|c|c|c|c|}
\hline & & numbers of samples & $\begin{array}{l}\text { - Requirement of antibodies } \\
\text { or antigens labelling }\end{array}$ & \\
\hline & LFA & $\begin{array}{l}\text { - Simplicity to } \\
\text { operate } \\
\text { - Sensitive } \\
\text { - Low cost } \\
\text { - Reliable } \\
\text { - Specific } \\
\text { - Possibility of } \\
\text { detecting bacterial } \\
\text { toxins }\end{array}$ & $\begin{array}{l}\text { - Requirement of antibodies } \\
\text { and/or antigens for labelling }\end{array}$ & $\begin{array}{l}\text { (Li and } \\
\text { Macdonald, } \\
\text { 2016; } \\
\text { Posthuma- } \\
\text { Trumpie et al., } \\
\text { 2009; Wu et } \\
\text { al., 2015) }\end{array}$ \\
\hline \multirow{5}{*}{$\begin{array}{l}\text { Nucleic acid- } \\
\text { based }\end{array}$} & PCR & $\begin{array}{l}\text { - Automated } \\
\text { - Desirable specificity } \\
\text { - Desirable sensitivity } \\
\text { - Reliable }\end{array}$ & $\begin{array}{l}\text { - Difficult to distinguish } \\
\text { between viable and non- } \\
\text { viable } \\
\text { cells } \\
\text { - Affected by PCR inhibitors } \\
\text { - Needs DNA Purification }\end{array}$ & $\begin{array}{l}\text { (Law et al., } \\
\text { 2014; Lazcka et } \\
\text { al., 2007; P. K. } \\
\text { Mandal et al., } \\
\text { 2011) }\end{array}$ \\
\hline & LAMP & $\begin{array}{l}\text { - Low cost } \\
\text { - Desirable sensitivity } \\
\text { - Desirable specificity } \\
\text { - No need for } \\
\text { thermal } \\
\text { cycling system } \\
\text { - Easy to operate }\end{array}$ & $\begin{array}{l}\text { - Insufficient to detect } \\
\text { unknown or un-sequenced } \\
\text { targets } \\
\text { - Complication of primer } \\
\text { design }\end{array}$ & $\begin{array}{l}\text { (Law et al., } \\
\text { 2015) }\end{array}$ \\
\hline & RPA & $\begin{array}{l}\text { - High specificity } \\
\text { - Sensitivity } \\
\text { - Multiplexing is } \\
\text { possible } \\
\text { - Robust to biological } \\
\text { substances } \\
\text { - No initial heating }\end{array}$ & $\begin{array}{l}\text { - relatively long primer } \\
\text { chain ( } 30 \text { or more) } \\
\text { - Difficulties of optimization }\end{array}$ & $\begin{array}{l}\text { (Vignali, 2000; } \\
\text { Choi et al., } \\
\text { 2014; Lillis et } \\
\text { al., 2016) }\end{array}$ \\
\hline & NASBA & $\begin{array}{l}\text { - Desirable sensitivity } \\
\text { - Low cost } \\
\text { - High specificity } \\
\text { - Can detect viable } \\
\text { bacteria without } \\
\text { interference from } \\
\text { DNA from dead } \\
\text { bacteria } \\
\text { - Does not require } \\
\text { thermal cycling } \\
\text { system }\end{array}$ & - Complicated design & $\begin{array}{c}\text { (Law et al., } \\
\text { 2015) }\end{array}$ \\
\hline & HDA & $\begin{array}{l}\text { - Sensitive } \\
\text { - Simple primer } \\
\text { design } \\
\text { - Robust to biological }\end{array}$ & - Expensive enzymes & $\begin{array}{l}\text { Ramalingam et } \\
\text { al., 2009; } \\
\text { Mahalanabis et } \\
\text { al., 2010; }\end{array}$ \\
\hline
\end{tabular}




\begin{tabular}{|l|l|l|l|c|}
\hline & $\begin{array}{l}\text { substances } \\
\bullet \text { No initial heating } \\
\text { step }\end{array}$ & & $\begin{array}{c}\text { Zaghloul and } \\
\text { El-shahat, } \\
2014)\end{array}$ \\
\hline
\end{tabular}

\section{Conclusion and outlook}

Efficient detection of foodborne pathogens is an important priority for the food industry. Microfluidic technologies are suggested to improve the selectivity, sensitivity, and efficiency of pathogen detection and replace the current conventional labour-intensive and slow culturing methods for analysis of pathogens in foods. However, efficient multipathogen capturing from complex food samples for high-throughput multiplex analysis has remained elusive. This is mainly due to the lack of "universal bacterial adsorbents" with high binding affinity to various pathogens. To date, antibodies are the most commonly used molecules for recognition, capturing, and concentrating of target pathogens from food sample in integrated microfluidic devices. In recent years, other alternatives molecules, such as aptamers, lectins, phage endolysins, etc., have emerged as suitable candidates. Using molecularly imprinted polymers (MIPs) is another method, suggested for bacterial capturing through highly specific three-dimensional binding sites that are complementary to the analyte in size, shape, and orientation (Birnbaumer et al., 2009; Haupt Mosbach, K., 2000). However, this method also suffers from some disadvantages, such as incomplete template removal from the MIPs.

All the strategies suggested above can be integrated into microfluidic systems to promote the performance of pre-concentration and sample preparation steps separately or in combination with other techniques, such as acoustophoresis, magnetophoresis or filtration. Rapid detection technologies, such as nucleic acid amplification using PCR, LAMP, RPA or NASBA can be applied with optical or electrochemical techniques in microfluidic devices for rapid detection of foodborne pathogens. Although optical 
techniques usually provides better sensitivity than that of electrochemical detection, they are often more expensive and complicated (due to the integration of very sensitive optical detectors). Electrochemical-based microfluidics also requires improvement in terms of better performance and reproducibility.

In response to demands for lower price per test of pathogen detection by microfluidic devices, the field is rapidly switching from highly sophisticated fabrication technologies to polymer or paper-based devices that can fulfil the requirement of the end users. For example, most of the silicon-based devices are nowadays replaced with polymethyl methacrylate, polycarbonate, and polystyrene polymer chips to overcome limitations that stem from optically opaque properties and relatively high expense of fabrication. In addition, nitrocellulose paper-based devices offer many advantages, such as compatibility with most biological samples, ease of surface functionalization with various ligands, low cost, disposability, and capability to let all types of aqueous solutions moving through the devices. Additionally, the papers contain well-defined and distributed pores within their structure, which allow size dependent separation of sample molecules (Kim et al., 2014; Zhang et al., 2015). In the near future, all these methods can be integrated within microfluidic systems and connect to smart phone technologies to generate the next generation of LOC systems that enable pathogen monitoring directly from foods (Xu et al., 2015). In the end, it is worth pointing out that access to safe food is now much closer to a satisfactory level than ever before. However, more efforts are needed to move the labscale LOC studies to industrial mass production level in order to achieve optimal tools for faster online or at site food analysis to improve food safety, healthcare, and quality of life.

\section{Acknowledgements}


This work was financially supported by the European Union's Horizon 2020 research and innovation program, grant agreement No. 687697. 


\section{References}

Abdallah, A., Van Den Driesche, S., Brandhoff, L., Bunge, F., Akhtar, M., Ebrahimifard, R., Clara, S., Jakoby, B., Vellekoop, M.J., 2015. Microfluidic device for acoustophoresis and dielectrophoresis assisted particle and cell transfer between different fluidic media, in: Procedia Engineering. pp. 691-694.

Abidin, Z. Z., Gauri, S., Mahdi, M. A., Yunus, N.A.M., 2016. Pathogen detection by fiber optic microfluidic biosensor. J Biotechnol Biomater 6, 2155.

Adami, A., Mortari, A., Morganti, E., Lorenzelli, L., 2016. Microfluidic Sample Preparation Methods for the Analysis of Milk Contaminants. J. Sensors 2016, 1-9.

Agrawal, S., Morarka, A., Bodas, D., Paknikar, K.M., 2012. Multiplexed detection of waterborne pathogens in circular microfluidics. Appl. Biochem. Biotechnol. 167, 16681677.

Alexander, B.D., Pfaller, M.A., 2006. Contemporary tools for the diagnosis and management of invasive mycoses. Clin. Infect. Dis. 43, S15-S27.

Amin Almasi, M., 2012. Detection of Coat Protein Gene of the Potato Leafroll Virus by Reverse Transcription Loop-Mediated Isothermal Amplification. J. Plant Pathol. Microbiol. 4, 1-6.

Andresen, D., von Nickisch-Rosenegk, M., Bier, F.F., 2009. Helicase dependent OnChipamplification and its use in multiplex pathogen detection. Clin. Chim. Acta.

Angus, S. V, Kwon, H.-J., Yoon, J.-Y., 2012. Field-deployable and near-real-time optical microfluidic biosensors for single-oocyst-level detection of Cryptosporidium parvum from field water samples. J. Environ. Monit. 14, 3295-304.

Atalay, Y.T., Vermeir, S., Witters, D., Vergauwe, N., Verbruggen, B., Verboven, P., Nicolaï, B.M., Lammertyn, J., 2011. Microfluidic analytical systems for food analysis. Trends Food Sci. Technol. 22, 386-404.

Baid, A., 2016. ELISA- A Mini Review. Res. Rev. J. Pharm. Anal. 5, 1-8.

Ben Aissa, A., Jara, J.J., Sebasti??n, R.M., Vallribera, A., Campoy, S., Pividori, M.I., 2017. Comparing nucleic acid lateral flow and electrochemical genosensing for the simultaneous detection of foodborne pathogens. Biosens. Bioelectron. 88, 265-272.

Bhunia, A.K., 2014. One day to one hour: how quickly can foodborne pathogens be detected? Future Microbiol.

Bian, X., Jing, F., Li, G., Fan, X., Jia, C., Zhou, H., Jin, Q., Zhao, J., 2015. A microfluidic droplet digital PCR for simultaneous detection of pathogenic Escherichia coli $\mathrm{O} 157$ and Listeria monocytogenes. Biosens. Bioelectron.

Birnbaumer, G.M., Lieberzeit, P.A., Richter, L., Schirhagl, R., Milnera, M., Dickert, F.L., Bailey, A., Ertl, P., 2009. Detection of viruses with molecularly imprinted polymers integrated on a microfluidic biochip using contact-less dielectric microsensors. Lab Chip 9, 3549-3556.

Blue, R., Uttamchandani, D., 2016. Recent advances in optical fiber devices for microfluidics integration. J. Biophotonics 25, 13-25.

Boman, H.G., 1995. Peptide antibiotics and their role in innate immunity. Annu Rev Immunol 13, 61-92.

Borchman, D., Harris, E.N., Pierangeli, S.S., Lamba, O.P., 1995. Interactions and molecular structure of cardiolipin and beta 2-glycoprotein 1 (beta 2-GP1). Clin. Exp. Immunol. 102, 373-8.

Bosch, M.E., Sánchez, A.J.R., Rojas, F.S., Ojeda, C.B., 2007. Recent Development in Optical Fiber Biosensors. Sensors 7, 797-859. 
Bu, M., Christensen, T.B., Smistrup, K., Wolff, A., Hansen, M.F., 2008. Characterization of a microfluidic magnetic bead separator for high-throughput applications. Sensors Actuators, A Phys. 145-146, 430-436.

Buldini, P.L., Ricci, L., Sharma, J.L., 2002. Recent applications of sample preparation techniques in food analysis. J. Chromatogr. A.

Cappi, G., Spiga, F.M., Moncada, Y., Ferretti, A., Beyeler, M., Bianchessi, M., Decosterd, L., Buclin, T., Guiducci, C., 2015. Label-Free detection of tobramycin in serum by transmission-localized surface plasmon resonance. Anal. Chem. 87, 5278-5285.

CDC, 2017. Surveillance for Foodborne Disease Outbreaks United States, 2015: Annual Report.

Chen, G., Ding, M., 2013. A review of microfiber and nanofiber based optical sensors. Open Opt. J 32-57.

Chen, L., Mungroo, N., Daikuara, L., Neethirajan, S., 2015. Label-free NIR-SERS discrimination and detection of foodborne bacteria by in situ synthesis of $\mathrm{Ag}$ colloids. J. Nanobiotechnology 13, 45.

Chen, P., Chung, M.T., McHugh, W., Nidetz, R., Li, Y., Fu, J., Cornell, T.T., Shanley, T.P., Kurabayashi, K., 2015. Multiplex serum cytokine immunoassay using nanoplasmonic biosensor microarrays. ACS Nano 9, 4173-4181.

Chen, Q., Wang, D., Cai, G., Xiong, Y., Li, Y., Wang, M., Huo, H., Lin, J., 2016. Fast and sensitive detection of foodborne pathogen using electrochemical impedance analysis, urease catalysis and microfluidics. Biosens. Bioelectron. 86, 770-776.

Cheng, N., Zhu, L., Xu, Y., Xu, W., 2014. A Review of Test Strips in Rapid Detection of Food Safety. Austin J. Nutr. Food Sci. 2, 1038.

Cho, I.H., Bhunia, A., Irudayaraj, J., 2015. Rapid pathogen detection by lateral-flow immunochromatographic assay with gold nanoparticle-assisted enzyme signal amplification. Int. J. Food Microbiol. 206, 60-66.

Cho, Y.-K., Kim, T., Lee, J.-G., 2010. On-chip concentration of bacteria using a 3D dielectrophoretic chip and subsequent laser-based DNA extraction in the same chip. J. Micromechanics Microengineering 20, 65010.

Choi, G., Jung, J.H., Park, B.H., Oh, S.J., Seo, J.H., Choi, J.S., Kim, H., Seo, T.S., 2014. Lab on a Chip A centrifugal direct recombinase polymerase amplification (direct-RPA) microdevice for multiplex and real-time identification of food poisoning bacteria 16 .

Choi, J., Shin, D.-M., Song, H., Lee, D., Kim, K., 2016. Current achievements of nanoparticle applications in developing optical sensing and imaging techniques. Nano Converg. 3, 1-13.

Chung, S.H., Baek, C., Cong, V.T., Min, J., 2015. The microfluidic chip module for the detection of murine norovirus in oysters using charge switchable micro-bead beating. Biosens. Bioelectron. 67, 625-633.

Churruca, E., Girbau, C., Martínez, I., Mateo, E., Alonso, R., Fernández-Astorga, A., 2007. Detection of Campylobacter jejuni and Campylobacter coli in chicken meat samples by real-time nucleic acid sequence-based amplification with molecular beacons. Int. J. Food Microbiol. 117, 85-90.

Compton, J., 1991. Nucleic acid sequence-based amplification. Nature 350, 91-92.

Cooper, R.M., Leslie, D.C., Domansky, K., Jain, A., Yung, C., Cho, M., Workman, S., Super, M., Ingber, D.E., 2013. A microdevice for rapid optical detection of magnetically captured rare blood pathogens. Lab Chip 14, 182-188.

Corfield, A.P., 2015. Mucins: A biologically relevant glycan barrier in mucosal protection. Biochim. Biophys. Acta - Gen. Subj. 1850, 236-252. 
Coskun, A.F., Cetin, A.E., Galarreta, B.C., Alvarez, D.A., Altug, H., Ozcan, A., 2014. Lensfree optofluidic plasmonic sensor for real-time and label-free monitoring of molecular binding events over a wide field-of-view. Sci. Rep. 4, 6789.

Craig, A.P., Franca, A.S., Irudayaraj, J., 2013. Surface-enhanced Raman spectroscopy applied to food safety. Annu. Rev. Food Sci. Technol. 4, 369-80.

Dancho, B.A., Chen, H., Kingsley, D.H., 2012. Discrimination between infectious and noninfectious human norovirus using porcine gastric mucin. Int. J. Food Microbiol. 155, 222-226.

Demarco, D.R. and Lim, D. V, 2002. Detection of Escherichia coli O157 : H7 in 10- and 25Gram Ground Beef Samples with an Evanescent-Wave Biosensor with Silica and Polystyrene Waveguides AND. J. Food Prot. 65, 596-602.

Dharmasiri, U., Witek, M.A., Adams, A.A., Osiri, J.K., Hupert, M.L., Bianchi, T.S., Roelke, D.L., Soper, S.A., 2010. Enrichment and detection of Escherichia coli O157:H7 from water samples using an antibody modified microfluidic chip. Anal Chem 82, 28442849.

Dimov, I.K., Garcia-Cordero, J.L., O 'grady, J., Poulsen, C.R., Viguier, C., Kent, L., Daly, P., Lincoln, B., Maher, M., Kennedy, R.O.', Smith, T.J., Ricco, A.J., Lee, L.P., 2008 Integrated microfluidic tmRNA purification and real-time NASBA device for molecular diagnostics. Lab on a Chip 8, 2071-2078.

Dou, W., Tang, W., Zhao, G., 2013. A disposable electrochemical immunosensor arrays using 4-channel screen-printed carbon electrode for simultaneous detection of Escherichia coli O157:H7 and Enterobacter sakazakii. Electrochim. Acta 97, 79-85.

Duan, N., Chang, B., Zhang, H., Wang, Z., Wu, S., 2016. Salmonella typhimurium detection using a surface-enhanced Raman scattering-based aptasensor. Int. J. Food Microbiol. 218, 38-43.

Duarte, C., Salm, E., Dorvel, B., Reddy, B., Bashir, R., 2013. On-chip parallel detection of foodborne pathogens using loop-mediated isothermal amplification. Biomed. Microdevices 15, 821-830.

Dwivedi, H.P., Jaykus, L., 2011. Detection of pathogens in foods: the current state-of-theart and future directions. Crit. Rev. Microbiol. 37, 40-63.

Eid, C., Santiago, J.G., 2017. Assay for Listeria monocytogenes cells in whole blood using isotachophoresis and recombinase polymerase amplification. Analyst.

Epand, R.M., Epand, R.F., 2009a. Domains in bacterial membranes and the action of antimicrobial agents. Mol. Biosyst. 5, 580.

Epand, R.M., Epand, R.F., 2009b. Lipid domains in bacterial membranes and the action of antimicrobial agents. Biochim. Biophys. Acta - Biomembr. 1788, 289-294.

Eugster, M.R., Haug, M.C., Huwiler, S.G., Loessner, M.J., 2011. The cell wall binding domain of Listeria bacteriophage endolysin PlyP35 recognizes terminal GlcNAc residues in cell wall teichoic acid. Mol. Microbiol. 81, 1419-1432.

Fang, Z., Wu, W., Lu, X., Zeng, L., 2014. Lateral flow biosensor for DNA extraction-free detection of salmonella based on aptamer mediated strand displacement amplification. Biosens. Bioelectron. 56, 192-197.

Fernández-Baldo, M.A., Messina, G.A., Sanz, M.I., Raba, J., 2010. Microfluidic immunosensor with micromagnetic beads coupled to carbon-based screen-printed electrodes (SPCEs) for determination of botrytis cinerea in tissue of fruits. J. Agric. Food Chem. 58, 11201-11206.

Flannery, A., Gerlach, J.Q., Joshi, L., Kilcoyne, M., 2015. Assessing Bacterial Interactions Using Carbohydrate-Based Microarrays 690-713. 
Flemming, H., Wingender, J., 2010. The biofilm matrix. Nat. Rev. Microbiol. 8, 623-33.

Foudeh, A.M., Daoud, J.T., Faucher, S.P., Veres, T., Tabrizian, M., 2014. Sub-femtomole detection of 16s rRNA from Legionella pneumophila using surface plasmon resonance imaging. Biosens. Bioelectron. 52, 129-135.

Foudeh et al., 2012. Microfluidic designs and techniques using lab-on-a-chip devices for pathogen detection for point-of-care diagnostics. Lab Chip 12, 3249-66.

Fykse, E.M., Skogan, G., Davies, W., Olsen, J.S., Blatny, J.M., 2007. Detection of Vibrio cholerae by real-time nucleic acid sequence-based amplification. Appl. Environ. Microbiol.

Gao, J., Li, L., Ho, P.-L., Mak, G.C., Gu, H., Xu, B., 2006. Combining Fluorescent Probes and Biofunctional Magnetic Nanoparticles for Rapid Detection of Bacteria in Human Blood. Adv. Mater. 18, 3145-3148.

Gauri, S., Abidin, Z.Z., Kamuri, M.F., Mahdi, M.A., Yunus, N.A., 2017. Detection of Aeromonas hydrophila Using Fiber Optic Microchannel Sensor 2017.

Ghosh Dastider, S., Barizuddin, S., Yuksek, N.S., Dweik, M., Almasri, M.F., 2015. Efficient and rapid detection of salmonella using microfluidic impedance based sensing. J. Sensors 2015.

Gomez-Zavaglia, A., Li, B., Zeng, D., Chen, Z., Jiang, Y., Xue, F., 2016. Advances and Challenges in Viability Detection of Foodborne Pathogens. Front. Microbiol 7.

González, I., Fernández, L.J., Gómez, T.E., Berganzo, J., Soto, J.L., Carrato, A., 2010. A polymeric chip for micromanipulation and particle sorting by ultrasounds based on a multilayer configuration. Sensors Actuators, B Chem. 144, 310-317.

Gracie, K., Correa, E., Mabbott, S., Dougan, J.A., Graham, D., Goodacre, R., Faulds, K., 2014. Simultaneous detection and quantification of three bacterial meningitis pathogens by SERS. Chem. Sci. 5, 1030-1040.

Granger, J.H., Schlotter, N.E., Crawford, A.C., Porter, M.D., 2016. Prospects for point-ofcare pathogen diagnostics using surface-enhanced Raman scattering (SERS). Chem. Soc. Rev. 45, 3865-3882.

Guan, X., Zhang, H.J., Bi, Y.N., Zhang, L., Hao, D.L., 2010. Rapid detection of pathogens using antibody-coated microbeads with bioluminescence in microfluidic chips. Biomed. Microdevices 12, 683-691.

Guo, P.L., Tang, M., Hong, S.L., Yu, X., Pang, D.W., Zhang, Z.L., 2015. Combination of dynamic magnetophoretic separation and stationary magnetic trap for highly sensitive and selective detection of Salmonella typhimurium in complex matrix. Biosens. Bioelectron. 74, 628-636.

Hahm, B.K., Kim, H., Singh, A.K., Bhunia, A.K., 2015. Pathogen enrichment device (PED) enables one-step growth, enrichment and separation of pathogen from food matrices for detection using bioanalytical platforms. J. Microbiol. Methods 117, 64-73.

Haupt Mosbach, K., K., 2000. Molecularly imprinted polymers and their use in biomimmetic sensors. Chem. Rev. 100, 2495-2504.

Hejazian, M., Li, W., Nguyen, N.-T., 2015. Lab on a chip for continuous-flow magnetic cell separation. Lab Chip 15, 959-970.

Hernandez, F.J., Ozalp, V.C., 2012. Graphene and other nanomaterial-based electrochemical aptasensors. Biosensors.

Huang, S., Do, J., Mahalanabis, M., Fan, A., Zhao, L., Jepeal, L., Singh, S.K., Klapperich, C.M., 2013. Low Cost Extraction and Isothermal Amplification of DNA for Infectious Diarrhea Diagnosis. PLoS One.

Huang, Z., Cui, X., Xie, Q.-Y., Liu, D.-F., Lai, W.-H., 2016. Short communication: A novel 
method using immunomagnetic separation with a fluorescent nanobeads lateral flow assay for the rapid detection of low-concentration Escherichia coli O157:H7 in raw milk. J. Dairy Sci. 99, 9581-9585.

Hung, T.Q., Chin, W.H., Sun, Y., Wolff, A., Bang, D.D., 2016. A novel lab-on-chip platform with integrated solid phase PCR and Supercritical Angle Fluorescence (SAF) microlens array for highly sensitive and multiplexed pathogen detection.

IFSAC, 2017. Foodborne illness source attribution estimates for 2013 for Salmonella, Escherichia coli O157, Listeria monocytogenes, and Campylobacter using multi-year outbreak surveillance data, United States.

Ikeda, M., Yamaguchi, N., Tani, K., Nasu, M., 2006. Rapid and simple detection of food poisoning bacteria by bead assay with a microfluidic chip-based system. J. Microbiol. Methods 67, 241-247.

Im, H., Shao, H., Park, Y. II, Peterson, V.M., Castro, C.M., Weissleder, R., Lee, H., 2014. Label-free detection and molecular profiling of exosomes with a nano-plasmonic sensor. Nat. Biotechnol. 32, 490-495.

Inci, F., Filippini, C., Baday, M., Ozen, M.O., Calamak, S., Durmus, N.G., Wang, S., Hanhauser, E., Hobbs, K.S., Juillard, F., Kuang, P.P., Vetter, M.L., Carocci, M., Yamamoto, H.S., Takagi, Y., Yildiz, U.H., Akin, D., Wesemann, D.R., Singhal, A., Yang, P.L., Nibert, M.L., Fichorova, R.N., Lau, D.T.-Y., Henrich, T.J., Kaye, K.M., Schachter, S.C., Kuritzkes, D.R., Steinmetz, L.M., Gambhir, S.S., Davis, R.W., Demirci, U., 2015. Multitarget, quantitative nanoplasmonic electrical field-enhanced resonating device (NE ${ }^{2} \mathrm{RD}$ ) for diagnostics. Proc. Natl. Acad. Sci. 112, E4354E4363.

Jenïkovâ, G., Pazlarovâ, J., Demnerovâ, K., 2000. Detection of Salmonella in food samples by the combination of immunomagnetic separation and PCR assay. Int. Microbiol. 3, 225-229.

Jia, F., Duan, N., Wu, S., Ma, X., Xia, Y., Wang, Z., Wei, X., 2014. Impedimetric aptasensor for Staphylococcus aureus based on nanocomposite prepared from reduced graphene oxide and gold nanoparticles. Microchim. Acta 181, 967-974.

Kanayeva, D.A., Wang, R., Rhoads, D., Erf, G.F., Slavik, M.F., Tung, S., Li, Y., 2012. Efficient Separation and Sensitive Detection of Listeria monocytogenes Using an Impedance Immunosensor Based on Magnetic Nanoparticles, a Microfluidic Chip, and an Interdigitated Microelectrode. J. Food Prot. 75, 1951-1959.

Kang, J.H., Um, E., Diaz, A., Driscoll, H., Rodas, M.J., Domansky, K., Watters, A.L., Super, M., Stone, H.A., Ingber, D.E., 2015. Optimization of Pathogen Capture in Flowing Fluids with Magnetic Nanoparticles. Small 11, 5657-5666.

Kang, X., Pang, G., Chen, Q., Liang, X., 2013. Fabrication of Bacillus cereus electrochemical immunosensor based on double-layer gold nanoparticles and chitosan. Sensors Actuators, B Chem. 177, 1010-1016.

Kearns, H., Goodacre, R., Jamieson, L., Graham, D., Faulds, K., 2017. SERS Detection of Multiple Anti-microbial Resistant Pathogens using Nanosensors. Anal. Chem. acs.analchem.7b02653.

Khoshmanesh, K., Baratchi, S., Tovar-Lopez, F.J., Nahavandi, S., Wlodkowic, D., Mitchell, A., Kalantar-Zadeh, K., 2012. On-chip separation of Lactobacillus bacteria from yeasts using dielectrophoresis. Microfluid. Nanofluidics 12, 597-606.

Khoshmanesh, K., Nahavandi, S., Baratchi, S., Mitchell, A., Kalantar-zadeh, K., 2011. Dielectrophoretic platforms for bio-microfluidic systems. Biosens. Bioelectron. 26, 1800-1814. 
Kim, G., Moon, J.H., Moh, C.Y., Lim, J. guk, 2015. A microfluidic nano-biosensor for the detection of pathogenic Salmonella. Biosens. Bioelectron. 67, 243-247.

Kim, T.-H., Park, J., Kim, C.-J., Cho, Y.-K., 2014. Fully Integrated Lab-on-a-Disc for Nucleic Acid Analysis of Food-Borne Pathogens. Anal. Chem. 86, 3841-3848.

Ko, S., Grant, S.A., 2006. A novel FRET-based optical fiber biosensor for rapid detection of Salmonella typhimurium. Biosens. Bioelectron. 21, 1283-1290.

Kong, M., Ryu, S., 2015. Bacteriophage PBC1 and its endolysin as an antimicrobial agent against Bacillus cereus. Appl. Environ. Microbiol. 81, 2274-2283.

Kong, M., Sim, J., Kang, T., Nguyen, H.H., Park, H.K., Chung, B.H., Ryu, S., 2015. A novel and highly specific phage endolysin cell wall binding domain for detection of Bacillus cereus. Eur. Biophys. J.

Krishnan, J.N., Kim, C., Park, H.J., Kang, J.Y., Kim, T.S., Kim, S.K., 2009. Rapid microfluidic separation of magnetic beads through dielectrophoresis and magnetophoresis. Electrophoresis 30, 1457-1463.

Krõlov, K., Frolova, J., Tudoran, O., Suhorutsenko, J., Lehto, T., Sibul, H., Mäger, I., Laanpere, M., Tulp, I., Langel, Ü., 2014. Sensitive and rapid detection of chlamydia trachomatis by recombinase polymerase amplification directly from urine samples. J. Mol. Diagnostics 16, 127-135.

Kumar, S., Kumar, S., Ali, M.A., Anand, P., Agrawal, V.V., John, R., Maji, S., Malhotra, B.D., 2013. Microfluidic-integrated biosensors: Prospects for point-of-care diagnostics. Biotechnol. J. 8, 1267-1279.

Laczka, O., Maesa, J.M., Godino, N., del Campo, J., Fougt-Hansen, M., Kutter, J.P., Snakenborg, D., Muñoz-Pascual, F.X., Baldrich, E., 2011. Improved bacteria detection by coupling magneto-immunocapture and amperometry at flow-channel microband electrodes. Biosens. Bioelectron. 26, 3633-3640.

Lakhin, A. V, Tarantul, V.Z., Gening, L. V, 2013. Aptamers: problems, solutions and prospects. Acta Naturae 5, 34-43.

Law, J.W.-F., Ab Mutalib, N.-S., Chan, K.-G., Lee, L.-H., 2015. Rapid methods for the detection of foodborne bacterial pathogens: principles, applications, advantages and limitations. Front. Microbiol. 5, 770.

Lazcka, O., Campo, F.J. Del, Muñoz, F.X., 2007. Pathogen detection: A perspective of traditional methods and biosensors. Biosens. Bioelectron.

Lee, H., Xu, L., Ahn, B., Lee, K., Oh, K.W., 2012. Continuous-flow in-droplet magnetic particle separation in a droplet-based microfluidic platform. Microfluid. Nanofluidics 13, 613-623.

Lee, J.J., Jeong, K.J., Hashimoto, M., Kwon, A.H., Rwei, A., Shankarappa, S.A., Tsui, J.H., Kohane, D.S., 2014. Synthetic ligand-coated magnetic nanoparticles for microfluidic bacterial separation from blood. Nano Lett. 14, 1-5.

Lee, W., Kwon, D., Choi, W., Jung, G.Y., Jeon, S., 2015. 3D-printed microfluidic device for the detection of pathogenic bacteria using size-based separation in helical channel with trapezoid cross-section. Sci. Rep. 5, 7717.

Lee, W., Kwon, D., Chung, B., Jung, G.Y., Au, A., Folch, A., Jeon, S., 2014. Ultrarapid detection of pathogenic bacteria using a $3 \mathrm{D}$ immunomagnetic flow assay. Anal. Chem. 86, 6683-6688.

Lei, K.F., 2012. Microfluidic systems for diagnostic applications: a review. J. Lab. Autom. 17, 330-47.

Lenshof, A., Laurell, T., 2010. Continuous separation of cells and particles in microfluidic systems. Chem. Soc. Rev. 39, 1203-1217. 
Lequin, R.M., 2005. Enzyme immunoassay (EIA)/enzyme-linked immunosorbent assay (ELISA). Clin. Chem. 51, 2415-2418.

$\mathrm{Li}, \mathrm{H} ., 2017$. Development of multiple cross displacement amplification label-based gold nanoparticles lateral flow biosensor for detection of Listeria monocytogenes.

Li, J., Macdonald, J., 2016. Biosensors and Bioelectronics Multiplexed lateral fl ow biosensors: Technological advances for radically improving point-of-care diagnoses. Biosens. Bioelectron. 83, 177-192.

Li, Q., Yuan, Y., 2016. Application of Vertical Electrodes in Microfluidic Channels for Impedance Analysis. Micromachines 7, 96.

Li, X., Ximenes, E., Amalaradjou, M.A.R., Vibbert, H.B., Foster, K., Jones, J., Liu, X., Bhunia, A.K., Ladisch, M.R., 2013. Rapid sample processing for detection of foodborne pathogens via cross-flow microfiltration. Appl. Environ. Microbiol. 79, 70487054.

Lillis, L., Siverson, J., Lee, A., Cantera, J., Parker, M., Piepenburg, O., Lehman, D.A., Boyle, D.S., 2016. Factors influencing Recombinase polymerase amplification (RPA) assay outcomes at point of care. Mol. Cell. Probes 30, 74-78.

Lim, C.T., Zhang, Y., 2007. Bead-based microfluidic immunoassays: The next generation. Biosens. Bioelectron.

Lin, C., Chang, W., Wang, C., Lee, C., Chen, T., Jan, F., Lee, G., 2015. A micro fl uidic system integrated with buried optical fi bers for detection of Phalaenopsis orchid pathogens \$. Biosens. Bioelectron. 63, 572-579.

Liu, C., Wang, S., Chen, G., Xu, S., Jia, Q., Zhou, J., Xu, W., 2014. A surface-enhanced Raman scattering (SERS)-active optical fiber sensor based on a three-dimensional sensing layer. Sens. Bio-Sensing Res. 1, 8-14.

Liu, Y., Ye, J., Li, Y., 2003. Rapid detection of Escherichia coli O157:H7 inoculated in ground beef, chicken carcass, and lettuce samples with an immunomagnetic chemiluminescence fiber-optic biosensor. J. Food Prot. 66, 512-517.

Luka, G., Ahmadi, A., Najjaran, H., Alocilja, E., Derosa, M., Wolthers, K., Malki, A., Aziz, H., Althani, A., Hoorfar, M., 2015. Microfluidics integrated biosensors: A leading technology towards lab-on-A-chip and sensing applications. Sensors (Switzerland) 15, 30011-30031.

Ma, X., Jiang, Y., Jia, F., Yu, Y., Chen, J., Wang, Z., 2014. An aptamer-based electrochemical biosensor for the detection of Salmonella. J. Microbiol. Methods 98, 94-98.

Mahalanabis, M., Do, J., Almuayad, H., Zhang, J.Y., Klapperich, C.M., 2010. An integrated disposable device for DNA extraction and helicase dependent amplification. Biomed. Microdevices.

Mairhofer, J., Roppert, K., Ertl, P., 2009. Microfluidic systems for pathogen sensing: A review. Sensors (Switzerland) 9, 4804-4823.

Mandal, P.K., Biswas, A.K., Choi, K., Pal, U.K., 2011. Methods for Rapid Detection of Foodborne Pathogens: An Overview. Am. J. Food Technol.

Mangal, M., Bansal, S., Sharma, S.K., Gupta, R.K., 2017. Critical Reviews in Food Science and Nutrition Molecular Detection of Foodborne Pathogens: A Rapid and Accurate Answer to Food Safety Molecular Detection of Foodborne Pathogens: A Rapid and Accurate Answer to Food Safety.

Mannoor, M.S., Zhang, S., Link, A.J., McAlpine, M.C., 2010. Electrical detection of pathogenic bacteria via immobilized antimicrobial peptides. Proc. Natl. Acad. Sci. 107, 19207-19212. 
Marazuela, M.D., Moreno-Bondi, M.C., 2002. Fiber-optic biosensors - An overview. Anal. Bioanal. Chem. 372, 664-682.

Martel, J.M., Toner, M., 2012. Inertial focusing dynamics in spiral microchannels. Phys. Fluids 24.

Matsuzaki, K., Sugishita, K., Harada, M., Fujii, N., Miyajima, K., 1997. Interactions of an antimicrobial peptide, Imodernstylenos\{magainin 2$\}$, with outer and inner membranes of Gram-negative bacteria. Biochim Biophys Acta 1327, 119-130.

Mayer, K.M., Hafner, J.H., Antigen, A.À., 2011. Localized surface plasmon resonance sensors. Chem. Rev. 111, 3828-3857.

Moore, M.D., Jaykus, L.-A., 2016. Development of a Recombinase Polymerase Amplification Assay for Detection of Epidemic Human Noroviruses. Nat. Publ. Gr.

Morant-Miñana, M.C., Elizalde, J., 2015. Microscale electrodes integrated on COP for real sample Campylobacter spp. detection. Biosens. Bioelectron. 70, 491-7.

Mori, Y., Kanda, H., Notomi, T., 2013. Loop-mediated isothermal amplification (LAMP): recent progress in research and development. J. Infect. Chemother. 19, 404-11.

Mungroo, N.A., Oliveira, G., Neethirajan, S., 2016. SERS based point-of-care detection of food-borne pathogens. Microchim. Acta 183, 697-707.

Murinda, S.E., Ibekwe, A.M., Zulkaffly, S., Cruz, A., Park, S., Razak, N., Paudzai, F.M., Samad, L.A., Baquir, K., Muthaiyah, K., Santiago, B., Rusli, A., Balkcom, S., 2014. Real-Time Isothermal Detection of Shiga Toxin-Producing Escherichia coli Using Recombinase Polymerase Amplification. Foodborne Pathogens and Disease. 11, 529536

Nagamine, K., Hase, T., Notomi, T., 2002. Accelerated reaction by loop-mediated isothermal ampli ${ }^{\circledR}$ cation using loop primers 223-229.

Newman, K.L., Leon, J.S., Rebolledo, P.A., Scallan, E., 2015. The impact of socioeconomic status on foodborne illness in high-income countries: a systematic review. Epidemiol. Infect. 143, 2473-85.

Ng, A.H.C., Uddayasankar, U., Wheeler, A.R., 2010. Immunoassays in microfluidic systems. Anal. Bioanal. Chem.

Ngamsom, B., Esfahani, M.M.N., Phurimsak, C., Lopez-Martinez, M.J., Raymond, J.C., Broyer, P., Patel, P., Pamme, N., 2016a. Multiplex sorting of foodborne pathogens by on-chip free-flow magnetophoresis. Anal. Chim. Acta 918, 69-76.

Ngamsom, B., Lopez-Martinez, M.J., Raymond, J.C., Broyer, P., Patel, P., Pamme, N., $2016 \mathrm{~b}$. On-chip acoustophoretic isolation of microflora including $\mathrm{S}$. typhimurium from raw chicken, beef and blood samples. J. Microbiol. Methods 123, 79-86.

Nguyen, H.H., Park, J., Kang, S., Kim, M., 2015. Surface plasmon resonance: A versatile technique for biosensor applications. Sensors (Switzerland) 15, 10481-10510.

Niessen, L., Luo, J., Denschlag, C., Vogel, R.F., 2013. The application of loop-mediated isothermal ampli fi cation ( LAMP ) in food testing for bacterial pathogens and fungal contaminants. Food Microbiol. 36, 191-206.

Notomi, T., 2000. Loop-mediated isothermal amplification of DNA. Nucleic Acids Res. 28, $63 \mathrm{e}-63$.

O'Grady, J., Lacey, K., Glynn, B., Smith, T.J., Barry, T., Maher, M., 2009. TmRNA - A novel high-copy-number RNA diagnostic target - Its application for Staphylococcus aureus detection using real-time NASBA. FEMS Microbiol. Lett.

Oh, S.J., Park, B.H., Jung, J.H., Choi, G., Lee, D.C., Kim, D.H., Seo, T.S., 2016. Centrifugal loop-mediated isothermal amplification microdevice for rapid, multiplex and colorimetric foodborne pathogen detection. Biosens. Bioelectron. 75, 293-300. 
Ohk, S.-H., Bhunia, A.K., 2012. Multiplex fiber optic biosensor for detection of Listeria monocytogenes, Escherichia coli O157:H7 and Salmonella enterica from ready-to-eat meat samples. Food Microbiol. 33, 166-171.

Oscar, S.-V., Fernando, O.-C.L., del Pilar, C.-M.M., 2017. Total polyphenols content in white wines on a microfluidic flow injection analyzer with embedded optical fibers. Food Chem. 221, 1062-1068.

Ozalp, V.C., Bayramoglu, G., Erdem, Z., Arica, M.Y., 2015. Pathogen detection in complex samples by quartz crystal microbalance sensor coupled to aptamer functionalized core-shell type magnetic separation. Anal. Chim. Acta 853, 533-540.

Páez-Avilés, C., Juanola-Feliu, E., Punter-Villagrasa, J., del Moral Zamora, B., HomsCorbera, A., Colomer-Farrarons, J., Miribel-Català, P., Samitier, J., 2016. Combined Dielectrophoresis and Impedance Systems for Bacteria Analysis in Microfluidic OnChip Platforms. Sensors 16, 1514.

Pamme, N., Eijkel, J.C.T., Manz, A., 2006. On-chip free-flow magnetophoresis: Separation and detection of mixtures of magnetic particles in continuous flow. J. Magn. Magn. Mater. 307, 237-244.

Pazos-Perez, N., Pazos, E., Catala, C., Mir-Simon, B., Gomez-De Pedro, S., Sagales, J., Villanueva, C., Vila, J., Soriano, A., Garcia De Abajo, F.J., Alvarez-Puebla, R.A., 2016. Ultrasensitive multiplex optical quantification of bacteria in large samples of biofluids. Sci. Rep. 6.

Perumal, V., Hashim, U., 2014. Advances in biosensors: Principle, architecture and applications. J. Appl. Biomed. 12, 1-15.

Piepenburg, O., Williams, C.H., Stemple, D.L., Armes, N.A., 2006. DNA detection using recombination proteins. PLoS Biol.

Posthuma-Trumpie, G.A., Korf, J., Van Amerongen, A., 2009. Lateral flow (immuno)assay: Its strengths, weaknesses, opportunities and threats. A literature survey. Anal. Bioanal. Chem. 393, 569-582.

Quesada-González, D., Merkoçi, A., 2015. Nanoparticle-based lateral flow biosensors. Biosens. Bioelectron. 73, 47-63.

Ramalingam, N., San, T.C., Kai, T.J., Mak, M.Y.M., Gong, H.Q., 2009. Microfluidic devices harboring unsealed reactors for real-time isothermal helicase-dependent amplification. Microfluid. Nanofluidics 7, 325-336.

Ramaswamy, B., Yeh, Y.-T.T., Zheng, S.-Y., 2013. Microfluidic device and system for point-of-care blood coagulation measurement based on electrical impedance sensing. Sensors Actuators B Chem. 180, 21-27.

Renner, L.D., Zan, J., Hu, L.I., Martinez, M., Resto, P.J., Siegel, A.C., Torres, C., Hall, S.B., Slezak, T.R., Nguyen, T.H., Weibel, D.B., 2017. Detection of ESKAPE Bacterial Pathogens at the Point of Care Using Isothermal DNA-Based Assays in a Portable Degas- Actuated Microfluidic Diagnostic Assay Platform. Applied and environmental microbiology, 83, 2449-2516.

Ricciardi, A., Crescitelli, A., Vaiano, P., Quero, G., Consales, M., Pisco, M., Esposito, E., Cusano, A., 2015. Lab-on-Fiber Technology: A New Vision for Chemical and Biological Sensing. Analyst 8068-8079.

Roberts, I.S., 1996. The biochemistry and genetics of capsular polysaccharide production in bacteria. Annu. Rev. Microbiol. 50, 285-315.

Ronkainen, N.J., Halsall, H.B., Heineman, W.R., 2010. Electrochemical biosensors. Chem Soc Rev 39, 1747-1763.

Sajid, M., Kawde, A.N., Daud, M., 2015. Designs, formats and applications of lateral flow 
assay: A literature review. J. Saudi Chem. Soc. 19, 689-705.

Santiago-Felipe, S., Tortajada-Genaro, L.A., Morais, S., Puchades, R., Maquieira, Á., 2015. Isothermal DNA amplification strategies for duplex microorganism detection. Food Chem.

Sapsford, K.E., Bradburne, C., Delehanty, J.B., Medintz, I.L., 2008. Sensors for detecting biological agents. Mater. Today 11, 38-49.

Sasso, L.A., Johnston, I.H., Zheng, M., Gupte, R.K., Ündar, A., Zahn, J.D., 2012. Automated microfluidic processing platform for multiplexed magnetic bead immunoassays. Microfluid. Nanofluidics 13, 603-612.

Sayad, A.A., Ibrahim, F., Uddin, S.M., Pei, K.X., Mohktar, M.S., Madou, M., Thong, K.L., 2016. A microfluidic lab-on-a-disc integrated loop mediated isothermal amplification for foodborne pathogen detection. Sensors Actuators B Chem. 227, 600-609.

Scallan, E., Hoekstra, R.M., Mahon, B.E., Jones, T.F., Griffin, P.M., 2015. An assessment of the human health impact of seven leading foodborne pathogens in the United States using disability adjusted life years. Epidemiol. Infect. 143, 2795-2804.

Scheler, O., Kaplinski, L., Glynn, B., Palta, P., Parkel, S., Toome, K., Maher, M., Barry, T., Remm, M., Kurg, A., 2011. Detection of NASBA amplified bacterial tmRNA molecules on SLICSel designed microarray probes. BMC Biotechnol. 11, 17.

Sengupta, A., Shende, C., Huang, H., Farquharson, S., Inscore, F., 2012. Rapid analysis of foodborne pathogens by surface-enhanced Raman spectroscopy. Sens. Agric. Food Qual. Saf. Iv 8369, 1-13.

Seo, S.-M., Cho, I.-H., Jeon, J.-W., Cho, H.-K., Oh, E.-G., Yu, H.-S., Shin, S.-B., Lee, H.J., Paek, S.-H., 2010. An ELISA-on-a-chip biosensor system coupled with immunomagnetic separation for the detection of Vibrio parahaemolyticus within a single working day. J. Food Prot. 73, 1466-73.

Shan, S., Lai, W., Xiong, Y., Wei, H., Xu, H., 2015. Novel strategies to enhance lateral flow immunoassay sensitivity for detecting foodborne pathogens. J. Agric. Food Chem. 63, 745-753.

Sharma, H., Mutharasan, R., 2013. Chemical Review of biosensors for foodborne pathogens and toxins. Sensors Actuators B Chem. 183, 535-549.

Shim, W.B., Song, J.E., Mun, H., Chung, D.H., Kim, M.G., 2014. Rapid colorimetric detection of Salmonella typhimuriumusing a selective filtration technique combined with antibody-magnetic nanoparticle nanocomposites. Anal. Bioanal. Chem. 406, 859-866.

Shu, B., Zhang, C., Xing, D., 2014. Segmented continuous-flow multiplex polymerase chain reaction microfluidics for high-throughput and rapid foodborne pathogen detection. Anal. Chim. Acta.

Simpkins, S.A., Chan, A.B., Hays, J., Popping, B., Cook, N., 2000. Erratum: An RNA transcription-based amplification technique (NASBA) for the detection of viable Salmonella enterica (Letters in Applied Microbiology (2000) 30 (75-79)). Lett. Appl. Microbiol.

Singh, A., Arutyunov, D., McDermott, M.T., Szymanski, C.M., Evoy, S., 2011. Specific detection of Campylobacter jejuni using the bacteriophage NCTC 12673 receptor binding protein as a probe. Analyst 136, 4780-4786.

Singh, R., Mukherjee, M. Das, Sumana, G., Gupta, R.K., Sood, S., Malhotra, B.D., 2014. Biosensors for pathogen detection: A smart approach towards clinical diagnosis. Sensors Actuators, B Chem. 197, 385-404.

Song, C., Liu, J., Li, J., Liu, Q., 2016. Dual FITC lateral flow immunoassay for sensitive 
detection of Escherichia coli O157:H7 in food samples. Biosens. Bioelectron. 85, 1-6. Stephen Inbaraj, B., Chen, B.H., 2016. Nanomaterial-based sensors for detection of foodborne bacterial pathogens and toxins as well as pork adulteration in meat products. J. Food Drug Anal. 24, 15-28.

Stöckel, S., Kirchhoff, J., Neugebauer, U., R??sch, P., Popp, J., 2016. The application of Raman spectroscopy for the detection and identification of microorganisms. J. Raman Spectrosc. 47, 89-109.

Sun, Y.-S., Li, C.-J., Hsu, J.-C., 2016. Integration of Curved D-Type Optical Fiber Sensor with Microfluidic Chip. Sensors 17, 63.

Sun, Y., Quyen, T.L., Hung, T.Q., Chin, W.H., Wolff, A., Bang, D.D., 2015. A lab-on-a-chip system with integrated sample preparation and loop-mediated isothermal amplification for rapid and quantitative detection of Salmonella spp. in food samples. Lab Chip 15, 1898-1904.

Sundaram, J., Park, B., Kwon, Y., Lawrence, K.C., 2013. Surface enhanced Raman scattering (SERS) with biopolymer encapsulated silver nanosubstrates for rapid detection of foodborne pathogens. Int. J. Food Microbiol. 167, 67-73.

Tachibana, H., Saito, M., Shibuya, S., Tsuji, K., Miyagawa, N., Yamanaka, K., Tamiya, E., 2015. On-chip quantitative detection of pathogen genes by autonomous microfluidic PCR platform. Biosens. Bioelectron.

Tan, F., Leung, P.H.M., Liu, Z. Bin, Zhang, Y., Xiao, L., Ye, W., Zhang, X., Yi, L., Yang, M., 2011. A PDMS microfluidic impedance immunosensor for $\mathrm{E}$. coli O157:H7 and Staphylococcus aureus detection via antibody-immobilized nanoporous membrane. Sensors Actuators, B Chem. 159, 328-335.

Tasoglu, S., Gurkan, U.A., Wang, S., Demirci, U., 2013. Manipulating biological agents and cells in micro-scale volumes for applications in medicine. Chem. Soc. Rev. 42, 5788-808.

Tawil, N., Mouawad, F., Lévesque, S., Sacher, E., Mandeville, R., Meunier, M., 2013. The differential detection of methicillin-resistant, methicillin-susceptible and borderline oxacillin-resistant Staphylococcus aureus by surface plasmon resonance. Biosens. Bioelectron. 49, 334-340.

Tawil, N., Sacher, E., Mandeville, R., Meunier, M., 2012. Surface plasmon resonance detection of E. coli and methicillin-resistant $\mathrm{S}$. aureus using bacteriophages. Biosens. Bioelectron. 37, 24-29.

Thiha, A., Ibrahim, F., 2015. A Colorimetric Enzyme-Linked Immunosorbent Assay (ELISA) Detection Platform for a Point-of-Care Dengue Detection System on a Lab-onCompact-Disc. Sensors (Basel). 15, 11431-11441.

Tian, P., Yang, D., Jiang, X., Zhong, W., Cannon, J.L., Burkhardt, W., Woods, J.W., Hartman, G., Lindesmith, L., Baric, R.S., Mandrell, R., 2010. Specificity and kinetics of norovirus binding to magnetic bead-conjugated histo-blood group antigens. J. Appl. Microbiol. 109, 1753-1762.

Tien, B.Q., Ngoc, N.T., Loc, N.T., Thu, V.T., Lam, T.D., 2017. Biochip for Real-Time Monitoring of Hepatitis B Virus (HBV) by Combined Loop-Mediated Isothermal Amplification and Solution-Phase Electrochemical Detection. J. Electron. Mater. 46, 3565-3571.

Tokel, O., Inci, F., Demirci, U., 2014. Advances in plasmonic technologies for point of care applications. Chem. Rev. 114, 5728-5752.

Tokel, O., Yildiz, U.H., Inci, F., Durmus, N.G., Ekiz, O.O., Turker, B., Cetin, C., Rao, S., Sridhar, K., Natarajan, N., Shafiee, H., Dana, A., Demirci, U., 2015. Portable 
microfluidic integrated plasmonic platform for pathogen detection. Sci. Rep. 5, 9152.

Tombelli, S., Minunni, M., Mascini, M., 2007. Aptamers-based assays for diagnostics, environmental and food analysis. Biomol. Eng. 24, 191-200.

Torres-Chavolla, E., Alocilja, E.C., 2009. Aptasensors for detection of microbial and viral pathogens. Biosens. Bioelectron. 24, 3175-3182.

Torun, Ö., Hakki Boyaci, I., Temür, E., Tamer, U., 2012. Comparison of sensing strategies in SPR biosensor for rapid and sensitive enumeration of bacteria. Biosens. Bioelectron. 37, 53-60.

Tourlousse, D.M., Ahmad, F., Stedtfeld, R.D., Seyrig, G., Tiedje, J.M., Hashsham, S.A., 2012. A polymer microfluidic chip for quantitative detection of multiple water-and foodborne pathogens using real-time fluorogenic loop-mediated isothermal amplification. Biomed. Microdevices 14, 769-778.

Tripathi, P., Upadhyay, N., Nara, S., 2017. Recent advancements in lateral flow immunoassays: a journey for toxin detection in food. Crit. Rev. Food Sci. Nutr. 8398, 00-00.

Unser, S., Bruzas, I., He, J., Sagle, L., 2015. Localized Surface Plasmon Resonance Biosensing: Current Challenges and Approaches. Sensors (Basel). 15, 15684-716.

Urrutia, A., Goicoechea, J., Arregui, F.J., 2015. Optical fiber sensors based on nanoparticle-embedded coatings. J. Sensors 2015.

Valadez, A.M., Lana, C.A., Tu, S., Morgan, M.T., Bhunia, A.K., Food, M., Drive, A.M., Lafayette, W., Lafayette, W., 2009. Evanescent Wave Fiber Optic Biosensor for Salmonella Detection in Food. sensors 5810-5824.

Velusamy, V., Arshak, K., Korostynska, O., Oliwa, K., Adley, C., 2010. An overview of foodborne pathogen detection: In the perspective of biosensors. Biotechnol. Adv.

Vidal, J.C., Bonel, L., Ezquerra, A., Hernández, S., Bertolín, J.R., Cubel, C., Castillo, J.R., 2013. Electrochemical affinity biosensors for detection of mycotoxins: A review. Biosens. Bioelectron.

Vignali, D.A.A., 2000. Multiplexed particle-based flow cytometric assays. J. Immunol. Methods 243, 243-255.

Vincent, M., Xu, Y., Kong, H., 2004. Helicase-dependent isothermal DNA amplification. EMBO Rep. 5, 795-800.

Viswanathan, S., Rani, C., Ho, J.A.A., 2012. Electrochemical immunosensor for multiplexed detection of food-borne pathogens using nanocrystal bioconjugates and MWCNT screen-printed electrode. Talanta 94, 315-319.

Vutukuru, M.R., Sharma, D.K., Ragavendar, M., Schmolke, S., Huang, Y., Gumbrecht, W., Mitra, N., 2016. A rapid, highly sensitive and culture-free detection of pathogens from blood by positive enrichment. J. Microbiol. Methods 131, 105-109.

Walter, A., März, A., Schumacher, W., Rösch, P., Popp, J., 2011. Towards a fast, high specific and reliable discrimination of bacteria on strain level by means of SERS in a microfluidic device. Lab Chip 11, 1013-1021.

Wan, Y., Zheng, L., Sun, Y., Zhang, D., 2014. Multifunctional semiconducting polymer dots for imaging, detection, and photo-killing of bacteria. J. Mater. Chem. B 2, 4818-4825.

Wang, C., Madiyar, F., Yu, C., Li, J., 2017. Detection of extremely low concentration waterborne pathogen using a multiplexing self-referencing SERS microfluidic biosensor. J. Biol. Eng. 11, 9.

Wang, D.S., Fan, S.K., 2016. Microfluidic surface plasmon resonance sensors: From principles to point-of-care applications. Sensors (Switzerland) 16.

Wang, J., 2005. Nanomaterial-based electrochemical biosensors. Analyst 130, 421. 
Wang, M., Zhao, C., Miao, X., Zhao, Y., Rufo, J., Liu, Y.J., Huang, T.J., Zheng, Y., 2015. Plasmofluidics: Merging Light and Fluids at the Micro-/Nanoscale. Small 11, 44234444.

Wang, R., Ni, Y., Xu, Y., Jiang, Y., Dong, C., Chuan, N., 2015. Immuno-capture and in situ detection of Salmonella typhimurium on a novel microfluidic chip. Anal. Chim. Acta 853, 710-717.

Wang, W., Liu, L., Song, S., Xu, L., Kuang, H., Zhu, J., Xu, C., 2017. Identification and quantification of eight Listeria monocytogene serotypes from Listeria spp. using a gold nanoparticle-based lateral flow assay. Microchim. Acta 184, 715-724.

Wang, X.D., Wolfbeis, O.S., 2016. Fiber-Optic Chemical Sensors and Biosensors (20132015). Anal. Chem. 88, 203-227.

Wang, X.D., Wolfbeis, O.S., 2013. Fiber-Optic Chemical Sensors and Biosensors (20082012). Anal. Chem. 85, 487-508.

Wang, Y.-M., Pang, X.-F., Zhang, Y.-Y., 2009. Recent advances in fiber-optic DNA biosensors. J. Biomed. Sci. Eng. 2, 312-317.

Wang, Y., Knoll, W., Dostalek, J., 2012. Bacterial pathogen surface plasmon resonance biosensor advanced by long range surface plasmons and magnetic nanoparticle assays. Anal. Chem. 84, 8345-8350.

Wang, Y., Ravindranath, S., Irudayaraj, J., 2011. Separation and detection of multiple pathogens in a food matrix by magnetic SERS nanoprobes. Anal. Bioanal. Chem. $399,1271-1278$.

Wang, Y., Salazar, J.K., 2016. Culture-Independent Rapid Detection Methods for Bacterial Pathogens and Toxins in Food Matrices. Compr. Rev. Food Sci. Food Saf. 15, 183205.

Wang, Z., Dai, Z., 2015. Carbon nanomaterial-based electrochemical biosensors: an overview. Nanoscale 7, 6420-6431.

Weidenmaier, C., Peschel, A., 2008. Teichoic acids and related cell-wall glycopolymers in Gram-positive physiology and host interactions. Nat.Rev.Microbiol. 6, 276-287.

WHO, 2015. WHO estimates of the global burden of foodborne diseases, WHO.

Wittenberg, N.J., Wootla, B., Jordan, L.R., Denic, A., Warrington, A.E., Oh, S.-H., Rodriguez, M., 2014. Applications of SPR for the characterization of molecules important in the pathogenesis and treatment of neurodegenerative diseases. Expert Rev. Neurother. 14, 449-63.

Wu, H., Zuo, Y., Cui, C., Yang, W., Ma, H., Wang, X., 2013. Rapid Quantitative Detection of Brucella melitensis by a Label-Free Impedance Immunosensor Based on a Gold Nanoparticle-Modified Screen-Printed Carbon Electrode. Sensors 13, 8551-8563.

Wu, S., Duan, N., Shi, Z., Fang, C., Wang, Z., 2014. Simultaneous aptasensor for multiplex pathogenic bacteria detection based on multicolor upconversion nanoparticles labels. Anal. Chem. 86, 3100-3107.

Wu, W., Zhao, S., Mao, Y., Fang, Z., Lu, X., Zeng, L., 2015. A sensitive lateral flow biosensor for Escherichia coli O157: $\mathrm{H} 7$ detection based on aptamer mediated strand displacement amplification. Anal. Chim. Acta 861, 62-68.

Xie, L., Xie, Z., Zhao, G., Liu, J., Pang, Y., Deng, X., Xie, Z., Fan, Q., Luo, S., 2014. A loop-mediated isothermal amplification assay for the visual detection of duck circovirus. Virol. J. 11, 1-6.

Xie, Y., Xu, L., Wang, Y., Shao, J., Wang, L., Wang, H., Qian, H., Yao, W., 2013. Labelfree detection of the foodborne pathogens of Enterobacteriaceae by surfaceenhanced Raman spectroscopy. Anal. Methods 5, 946. 
Xu, X., Akay, A., Wei, H., Wang, S., Pingguan-Murphy, B., Erlandsson, B.E., Li, X., Lee, W., Hu, J., Wang, L., Xu, F., 2015. Advances in Smartphone-Based Point-of-Care Diagnostics. Proc. IEEE 103, 236-247.

Yang, D., Zhou, H., Haisch, C., Niessner, R., Ying, Y., 2016. Reproducible E. coli detection based on label-free SERS and mapping. Talanta 146, 457-463.

Yang, L., Bashir, R., 2008. Electrical/electrochemical impedance for rapid detection of foodborne pathogenic bacteria. Biotechnol. Adv. 26, 135-150.

Yin, H.Y., Fang, T.J., Wen, H.W., 2016. Combined multiplex loop-mediated isothermal amplification with lateral flow assay to detect sea and seb genes of enterotoxic Staphylococcus aureus. Lett. Appl. Microbiol. 63, 16-24.

Yin, M., Huang, B., Gao, S., Zhang, A.P., Ye, X., 2016. Optical fiber LPG biosensor integrated microfluidic chip for ultrasensitive glucose detection. Biomed. Opt. Express 7, 2067.

Yoo, S.M., Kim, D.-K., Lee, S.Y., 2015. Aptamer-functionalized localized surface plasmon resonance sensor for the multiplexed detection of different bacterial species. Talanta $132,112-7$.

Yoo, S.M., Lee, S.Y., 2016. Optical Biosensors for the Detection of Pathogenic Microorganisms. Trends Biotechnol. 34, 7-25.

Yoon, J.-Y., Kim, B., 2012. Lab-on-a-Chip Pathogen Sensors for Food Safety. Sensors 12, 10713-10741.

You, D.J., Geshell, K.J., Yoon, J.Y., 2011. Direct and sensitive detection of foodborne pathogens within fresh produce samples using a field-deployable handheld device. Biosens. Bioelectron. 28, 399-406.

Yu, J., Zhang, Y., Zhang, Y., Li, H., Yang, H., Wei, H., 2016. Sensitive and rapid detection of staphylococcus aureus in milk via cell binding domain of lysin. Biosens. Bioelectron. 77, 366-371.

Zaghloul, H., El-Shahat, M., 2014. Recombinase polymerase amplification as a promising tool in hepatitis $C$ virus diagnosis. World J. Hepatol. 6, 916-922.

Zaytseva, N. V, Goral, V.N., Montagna, R.A., Baeumner, A.J., 2005. Development of a microfluidic biosensor module for pathogen detection. Lab Chip 5, 805-811.

Zeng, Y., Zhu, Z., Du, D., Lin, Y., 2016. Nanomaterial-based electrochemical biosensors for food safety. J. Electroanal. Chem. 781, 147-154.

Zhang, C., Khoshmanesh, K., Mitchell, A., Kalantar-Zadeh, K., 2010. Dielectrophoresis for manipulation of micro/nano particles in microfluidic systems. Anal. Bioanal. Chem.

Zhang, G., 2013. Foodborne Pathogenic Bacteria Detection: An Evaluation of Current and Developing Methods. McMaster Univ. Undergrad. Heal. Sci. journal. 1, 27-30.

Zhang, Y., Park, S., Liu, K., Tsuan, J., Yang, S., Wang, T.-H., 2011. A surface topography assisted droplet manipulation platform for biomarker detection and pathogen identification. Lab Chip 11, 398-406.

Zhang, Y., Zuo, P., Ye, B.-C., 2015. A low-cost and simple paper-based microfluidic device for simultaneous multiplex determination of different types of chemical contaminants in food. Biosens. Bioelectron. 68, 14-19.

Zhao, X., Dong, T., Yang, Z., Pires, N., Høivik, N., 2012. Compatible immuno-NASBA LOC device for quantitative detection of waterborne pathogens: design and validation. Lab Chip 12, 602.

Zhao, X., Lin, C.-W., Wang, J., Oh, D.H., 2014. Advances in rapid detection methods for foodborne pathogens. J. Microbiol. Biotechnol. 24, 297-312.

Zhao, Y., Wang, H., Zhang, P., Sun, C., Wang, X., Wang, X., Yang, R., Wang, C., Zhou, 
L., 2016. Rapid multiplex detection of 10 foodborne pathogens with an up-converting phosphor technology-based 10-channel lateral flow assay. Sci. Rep. 6, 21342.

Zhou, H., Yang, D., Ivleva, N.P., Mircescu, N.E., Niessner, R., Haisch, C., 2014. SERS detection of bacteria in water by in situ coating with Ag nanoparticles. Anal. Chem. 86, 1525-1533.

Zordan, M.D., Grafton, M.M.G., Acharya, G., Reece, L.M., Cooper, C.L., Aronson, A.I., Park, K., Leary, J.F., 2009. Detection of pathogenic E. coli O157:H7 by a hybrid microfluidic SPR and molecular imaging cytometry device. Cytom. Part A 75, 155162. 